Historic, Archive Document

Do not assume content reflects current scientific knowledge, policies, or practices. 


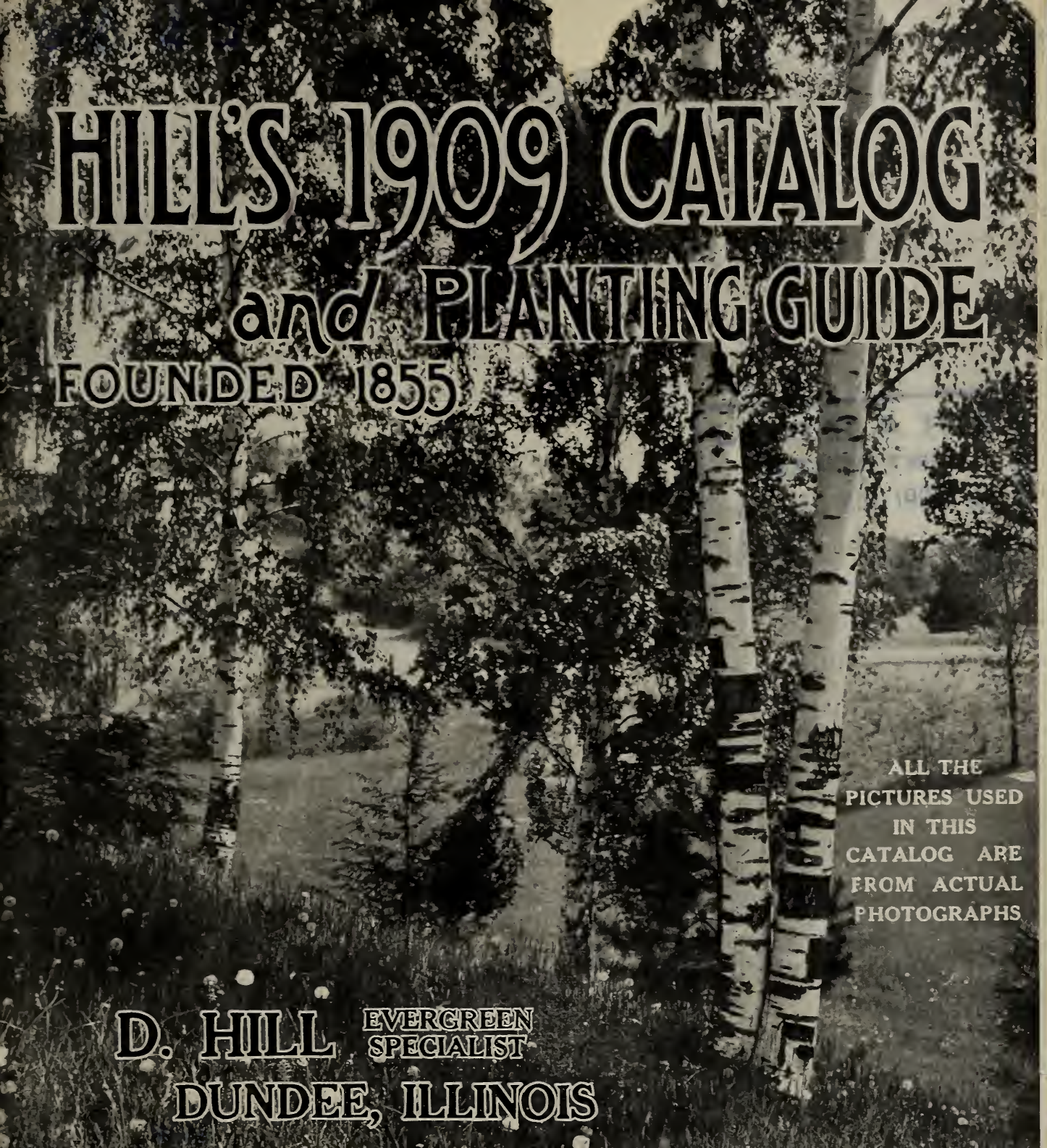




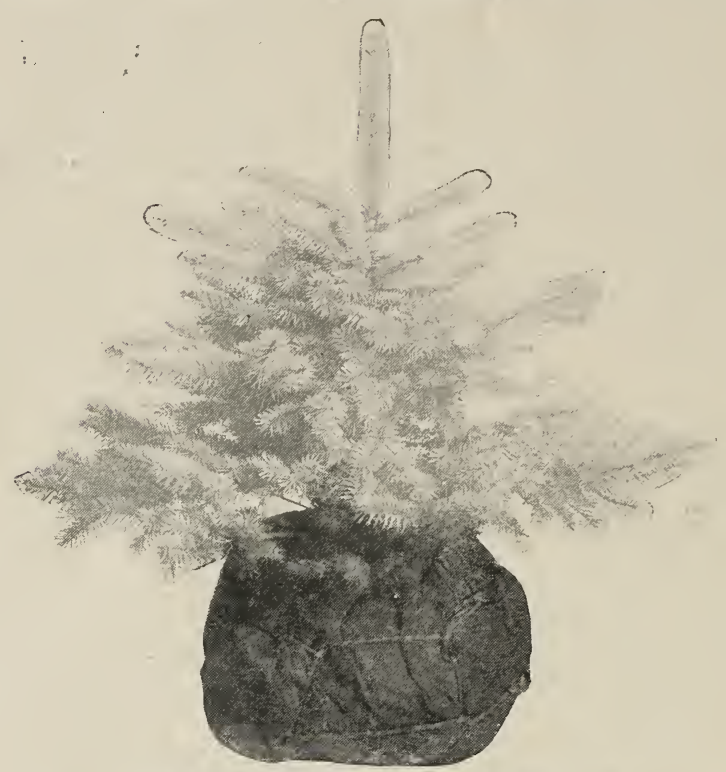

BEAUTIFUL GRAFTED BLUE SPRUCE.

IVe are now able to make you this SPECIAL OFFER because we have at last succeeded in getting a fine stock of this new, distinct and beautif:1 tree. We make the following splendid offer because we want to see this tree in every yarl. It excites the wonder and admiration of all. The bright sorgeous silvery blue tints, when flashed in the sunlight afford a wonderful aspect. These beautiful trees do not grow from seeds, but are carefully grafted under glass. We select only the perfect blue specimens from whicl to take our grafting wood. The illustration shows the tree dug with ball of earth and burlapped, ready to box and ship to you. Packed and delivered on cars for $\$ 1.35$.

Special Offer No. 100.

$\left.\begin{array}{c}1 \text { Grafted Biue Spruce } \\ 1 \text { to } 1 \frac{112}{\text { ft. B. }} \& \text { B. }\end{array}\right\} 1.35$

The Beautiful Grafted Blue Spruce.

THE NEW HARDY BLACK HILL SPRUCE.

To introduce this wonderful new variety we have set aside :several thousuand carefully grown plants. This tree is a direct. contrast to the Grafted Blue Spruce, its foliage being of a dark somber hue. In shape it is round, bushy and compact, growing to such fine form that it develops into round, symmetrical specimens without shearing. It has pleaseed thousands of customers all over the United States.

Special Offer $\left\{\begin{array}{l}3 \text { Black Hill Spruce, } 1 \text { to } 11 / 2 \text { feet. } \\ 6 \text { Norway Naple } 1 \text { to } 1 \frac{1}{2} \text { feet } \\ 2 \text { Pot }\end{array}\right\}$

No. 101. $\left\{\begin{array}{lll}2 & \text { American Linden, } 1 \text { to } 1 / 1 / 2 \text { f feet. } \\ 2 & \text { Purple Lilacs, } 1 \text { to } 1 \frac{1}{2} \text { feet. }\end{array}\right\} 75 \mathrm{c}$

\section{Special Offer No. 102.}

Nine Beautiful Flowering Shrubs, 3 of each variety described below. Strong 2-year Plants. $95 \mathrm{c}$

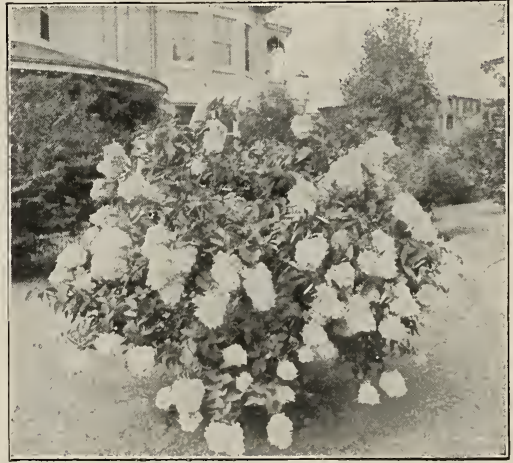

White Hydrangea.

HYDRANGEA. One of the best ornamental shrubs. Lilossoms profusely throughout July and August. The large massive white cone-shaped flowers often measure ten inches in length. See illustration.

SPIREA OR BRIDAI WREATH. A spdendid new garden shrub entirely hardy in any climate, and the most beautiful of all. Immense snow white blossoms, pure white flowers born in elegant plume-shaped clusters all over the plant as shown in illustration, page 23 . We believe this to be the finest of all Spireas and one of the most satisfactory shrubs to be had.

GOIDEN TOCK ORANGE. The Golden Mock Orange is one of the most attractive and beautiful shrubs we grow. Of vigorous habit, forming medium sized well formed compact bushes. The leaves are a rich golden color and contrast beautifully with the green of other slirubs. See Illustration, Page 25.

\section{Combination Offer No. 103.}

You can order any one of the above SPECIAI OFFERS, or as many as you want, but we will ship all three to you for the exceptionally low price of \$2.95. This is almost an unheard of offer and we are only enabled to do it because of our immense and wonderful stock, furthermore we want to lecome acquainted with you.

A Special Word. We invite your special attention to the fact that in this catalog all illustrations are made from actual photographs of stock as it stands in our own grounds or on the grounds of our customers who have purchased stock from us. In every case, therefore, our illustrations give an accurate pictures and descriptions in IIill's catalogs, just as you can depend upon the quality of Hill's trees.

We cannot change or alter in any way the SPECIAI OFFIRS at prices quoted. 


\section{HILL'S "DUNDEE GROWN" TREES RD Have Been Famous For Over Half a Century 91920}

\section{A WORD OF APPRECIATION.}

We wish here to express our sincere thanks to our many friends and patrons who have written kind words relative to the quality of stock and treatment they have received from us the past season. We greatly appreciate these expressions of confidence and shall endeavor to maintain the reputation they have so kindly given us.

\section{QUALITY.}

The wise purchaser in selecting what he wishes to buy considers the price of an articlé only as a guide. It is quality offered which he needs most to know, especially when buying Evergreens, shade trees, shrubs, etc. Trees bought at bargain-counter prices often prove to be very expensive before you are done with them. The question which mainly concerns a wise buyer of nursery stock is not, "What do these trees cost me?" but "Will the trees grow after I get them?" Our long years of experience in the growing, digging and packing of nursery stock have taught us the best methods to pursue, and we absolutely guarantee our stock to be as represented or your money back. Wre want you to know that when you buy from us you can depend upon getting your money's worth.

\section{YOUR SUCCESS WITH OUR TREES.}

is a matter in which we are mightily interested. Good stock is very necessary to begin with, but that is not all. Choosing the right varieties and giving them the proper care after you get them are quite as important. Some firms say, "When we deliver them to you in good condition, our responsibility ends." We go further, and guarantee results.

First-because we love trees and we want you to enjoy them also (entirely aside from any thought of commercialism on the part of either of us).

second-because we know our success is dependent upon your success. Therefore we endeavor to do everything reasonably within our power to help you succeed with the stock we send you.

\section{"INFORMATION CHEERFULLY GIVEN.”}

Write and ask us when in doubt. We will cheerfully answer your questions and give you the proper advice upon the stock we grow and sell. Some trees and plants are better adapted to some soils and conditions than others. Our many years of experience in shipping stock to every State in the Union, enables us to tell you the best to plant for good results. Our experience is at your command.

\section{SEEDLINGS AND TRANSPLANTS.}

We have designated our stock, particularly the evergreens, as "seedlings and "transplants," which offers you a wider range of selection in the size of the plants.

"Seedlings" are two, three and sometimes four year old plants that have not been taken from the ground and replanted, coming directly from the original seed beds.

"Transplants" are those which have been taken up and replanted. Transplanting adds value to the tree by developing an abundance of fibrous roots. The trees become heavy and stocky.

Seedlings should be planted upon a good piece of loose soil, well prepared to receive them, and well cultivated for two years, when they can be replanted for permanent use. It is our desire to offer each variety in as many sizes as possible, so that a selection can be made to suit your pocketbook.

TERMS.

Our terms are cash. To avold delay please send money with order. Money may be sent at our risk if forwarded by P. O. money order, Express money order, Bank draft, or in Registered letter. We prefer not to open accounts for amounts less than one hundred dollars, or to accept orders under 50 cents. Stock is furnished as follows:

\section{5 at 10 rate; 50 at 100 rate; 500 at 1,000 rate.}

\section{FREIGHT OR EXPRESS.}

Be sure to state the manner in which you wish your goods shipped. Write plainly Freight or Express. We use our own judgment when not advised by purchaser. Remember-there is now 20 per cent discount from regular express rates on nursery stock.

\section{BALL AND BURLAP.}

When we mention trees taken with ball of earth and burlapped, it means the trees will be dug leaving the earth still about their roots, around which is securely tied a piece of burlap to hold the dirt firmly in place. Trees designated "B \& B" will be dug with ball of earth and burlapped at price quoted. This in most cases absolutely guarantees their success. When planting these trees it is not necessary to remove burlap simply cut the strings and place the ball in hole. Always water well after planting.

\section{ORDER EARLY.}

You will find that it pays-no waiting, no worry, and you get better served, so be sure to allow yourself plenty of time. In ordering, please use the printed envelope and order sheet enclosed. Others will be sent upon request. Always write your name the same, adding the postoffice, county and State on each and every communication you send us. If you have occasion to write us. please use a separate sheet.

WE AIWAYS DO BITTPR THAN WI PROMISE in the way of extra trees anc plants so that when the order will at all afford it, we add to it something gratis, often
a choice or new kind.

\section{GET YOUR OWN TREES FREE.}

See our 50 Great Bargain Sheet and learn how you can get 100 trees free. Thousands of people took advantage of our generous club offers last year and got their own trees free. The only requirements are that you send us the complete addresses of the club names. For special prepaid shipments, see 50 Great Bargain Sheet.

Should this catalogue become mislaid and you are unable to remember the exact address, simply bear in mind, "Hill, Dundee, Ill." "That will reach us. Hill's Evergreens have made this village of Dundee famous the world over. We have many imitators, but be sure you get the genuine Hill's Dundee Grown.

Kindly send all orders, money and correspondence plainly addressed to

Established 1855 .

D. HIII, The Dundee Nurseries, Evergreen Specialist, 


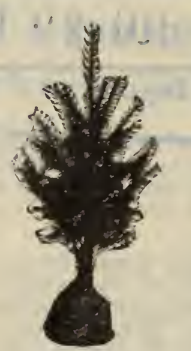

\section{EVERGREEN DEPARTMENT.}

IT MAKMS NO DIFFIRENCE whether you want Evergreens for lawn, park, wind-break or shelter belt, we have them and grown for all purposes.

NOTE: The term "B \& B" signifies that the items so designated are dug with ball of earth and tied in burlap.

\section{BALSAM FIR.}

Perhaps the oldest and best of the fast growing Evergreens for wind-break and shelter planting is the Balsam Fir. Tall, straight growing, with dark green foliage, and of fine appearance. We recommend the planting of this tree in all North and Northwestern States. Its extreme hardiness enables it to withstand the coldest of winter wind and weather. This is the variety whose needles emit the pleasing and

Balsam Fir. healthful fir odor.

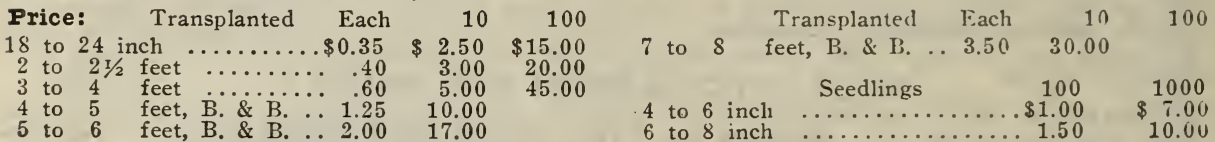

\section{HEMLOCK.}

A beautiful Evergreen of graceful habit. For garden, lawn and ornamental planting this variety stands out as one of the best. Attracts in all seasons, especially in the spring and early summer when the new growth comes forth a delicate light green, soft and fern like. It is one of the few shade enduring Evergreens, thriving in a partial shade, especially if planted in a moist soil. The best possible results are ob. tained when planting the Hemlock for Hedges. Hemlocks can be sheared in any desired form.

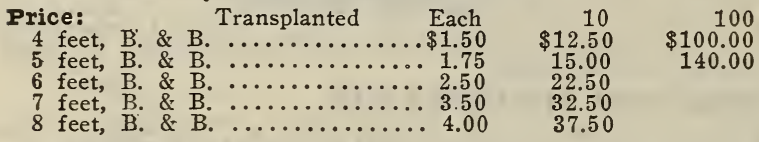

SHAARED IFMIOCKS. The Dundee Nurseries are famous for their beautiful Hernlocks. We have some special trees that have been sheared and carefully grown into perfect specimens. It takes years to grow such plants but we now have a fine stock in the large sizes, with excellent roots for moving with balls of earth.

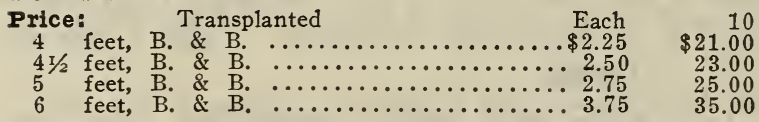

WrFPING FEM工OCK. Sargents Weeping Hemlock. Here we offer a tree especially for cemetery planting. Soft light green foliage upon delicate, graceful branches that bend over or droop in a most pleasing manner. These are choice, grafted plants especially grown for this purpose.

Price: Transplanted Each 10

1 to $11 / 2$ feet, B. \& B. .....\$1.50 \$13.50

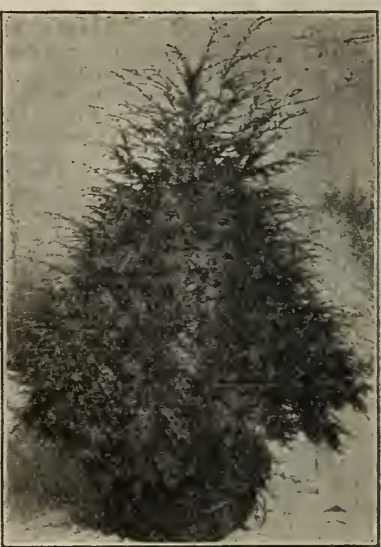

Hemlock.

Transplanted Each 10

\section{DOUGLAS FIR.}

Strong, upright habit of growth. Beautiful soft green foliage upon long drooping branches. Is much used for ornamental planting, also lawn group screen and wind-break planting. Native of the
Rocky Mountains and very hardy. Is one of the most rapid growing of all Evergreens. The demand for Douglas Fir has greatly increased within the last few years. It is a tree of merit and we recommend it as one of

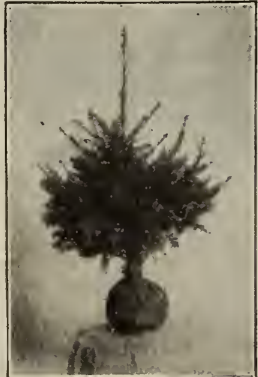

Douglas Fir. the best and safest of our large specimen Evergreens to plant. The medium sized trees are very desirable for wind-break planting. IVe always advise planting the Douglas Fir mixed with other varieties for wind-breaks. Norway Spruce, Douglas Fir and White Spruce make a good combination.

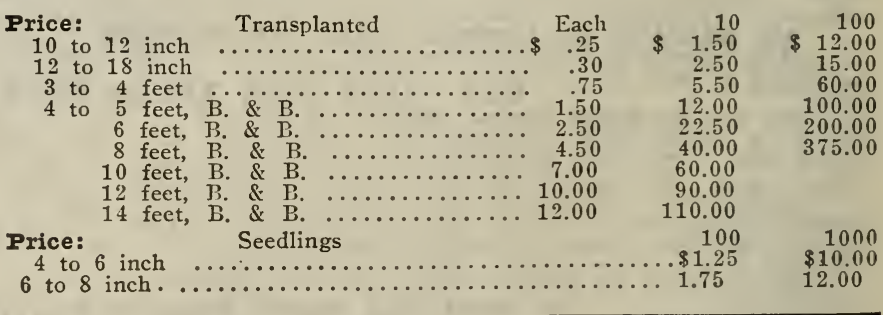




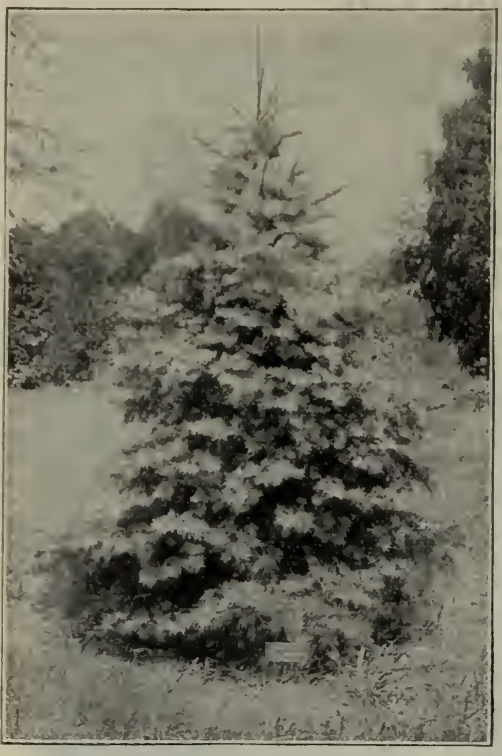

Concolor.

NORDMAN'S FIR.

\section{CONCOLOR.}

Another beautiful Evergreen from the Rocky Mountains. Its long, soft foliage varies in color from a delicate light green to a soft shade of blue.

Price: Transplanted Each 10

2 to 3 feet, B. \& B. . . . . . . \$ 2.00 \$ 17.50

3 feet, B. \& B. $\ldots \ldots \ldots \ldots \ldots .3 .00 \quad 27.50$

6 feet, B. \& B. $\cdots \cdots \cdots \cdots \cdots+5.00 \quad 45.00$

8 feet, B. \& B. $\ldots \ldots \ldots \ldots \ldots 10.00 \quad 95.00$

9 feet, B. \& B. ......... $11.00 \quad 100.00$

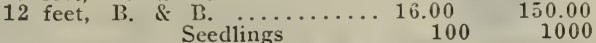

4 to 6 inch $\ldots \ldots \ldots \ldots \ldots \ldots \ldots \ldots 2.25 \quad \$ 17.00$

$\$$ to 10 inch $\ldots \ldots \ldots \ldots \ldots \ldots \ldots \ldots \ldots+3.50 \quad \$ 30.00$

10 to 12 inch $\ldots \ldots \ldots \ldots \ldots \ldots \ldots \ldots \ldots \ldots \ldots \ldots \ldots \ldots \ldots+4.50 \quad 40.00$

\section{"Novelty," the New Cork Bark Fir.}

One of the new Firs in cultivation, and when old is perhaps the most attractive of all, having bark of pure white color and is real cork.

OUR OFFER: Six 2-year seedlings for

$25 c$.

A rare and magnificent tree of remarkably symmetrical habit, naturally forming a perfect pyramid, clothed with a dense mass of dark green foliage. Considered one of our finest Firs and one of the choicest Evergreens for lawn specimens.

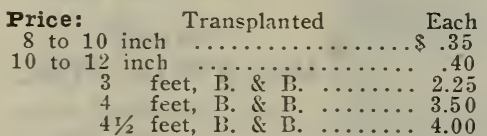

10
$\$ 3.00$
3.50
22.50
32.50
37.50

\section{RED CEDAR.}

A tall growing tree of great beauty and hardiness. One of the old reliable tested varieties. Its dense habit of growth makes it valuable as a wind-break tree; for north and western planting the common Red Cedar cannot be surpassed.

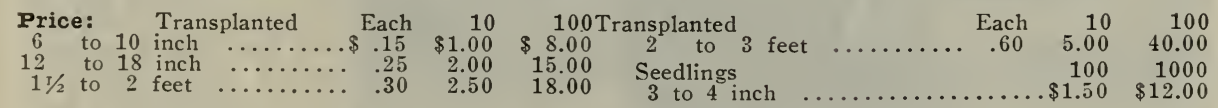

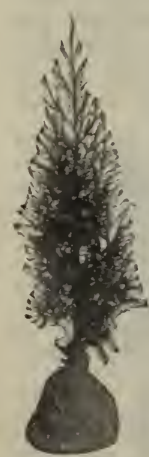

Often used for Cemetery planting. Tall and straight growing. Always neat and attractive and its formal habit of growth makes it desirable for many locations.
Price: Transplanted Each
10100 Transplanted

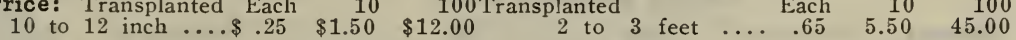
100

\section{TRAILING JUNIPER.}

The most useful of trailing or creeping Evergreens. It often covers an area of ground twelve feet in diameter adding beauty and attractiveness to its surroundings.

Price: Transplanted Each 10Seedlings 100 8 to 12 inch $\ldots \ldots \ldots \ldots \ldots \$ .25 \$ 2.00$ to 8 inch $\ldots \ldots \ldots \ldots \ldots \ldots 4.00$

\section{SAVIN JUNIPER.}

Another hardy Evergreen of prostrate habit. It is very beautiful with dark somber green foliage, useful and ornamental in many ways.
Price:
Transplanted
Each
6 to 8 inch
T.....................
$\$ .20$
$\$ 1.50$
10
1.50 $\quad \$ 10.00$

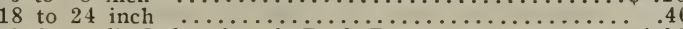
9.00

Red Cedar. 


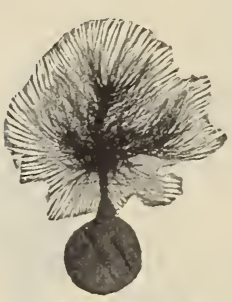

Austrian Pine.

\section{AUSTRIAN PINE.}

Plant Austrian Pine for wind-breaks, screens and shelters. They are fast growing and very hardy, withstanding any climate. SPECIAL: Our strong, heavy seedlings are suitable for wind-break planting right now. Plow the ground and plant one foot apart, cultivating thoroughly the first two years.

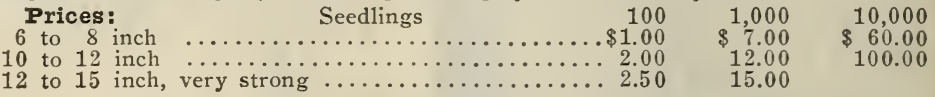

\section{JACK PINE.}

Grows and thrives on barren, sandy soils where other trees could not live. It is especially valuable for the western States. Rapid in growth and attains great size.

\begin{tabular}{|c|c|c|c|c|c|c|}
\hline $\begin{array}{l}\text { Prices: } \\
4 \text { to } 6 \text { inch } \\
8 \text { to } 10 \text { inch }\end{array}$ & 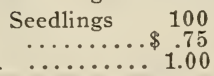 & $\begin{array}{r}1,000 \\
\$ 4.00 \\
8.00\end{array}$ & $\begin{array}{r}10,000 \\
\$ 35.00 \\
70.00\end{array}$ & $\begin{array}{l}12 \text { to } 15 \text { in., } \\
15 \text { to } 18 \text { in., }\end{array}$ & $\begin{array}{l}\text { Seedlings } \quad 100 \\
\text { strong ....\$1.75 } \\
\text { extra strong } 2.50\end{array}$ & $\begin{array}{r}1,000 \\
\$ 12.00 \\
15.00\end{array}$ \\
\hline
\end{tabular}

\section{PONDEROSA PINE.}

One of the most reliable, fast growing kinds we offer. Will do well on poor soil, but when planted on good, soft soil, its rapid growth is surprising. It has been the leading wind-break Evergreen for over fifty years. Ponderosa Pine, Austrian Pine and Norway Spruce planted in three rows ten feet apart breaking joints, make a most satisfactory wind-break.

$\begin{array}{llllllll}\text { Prices: } & \text { Transplanted Each } & 10 & 100 & \text { Seedlings } & 100 & 1,000 & 10,000\end{array}$ 8 to 10 inch $\ldots \ldots \ldots \ldots \ldots \$ .10 \quad \$ .75 \quad \$ 3.00 \quad 6$ to 8 inch $\ldots \ldots \ldots \ldots \ldots 1.00 \quad \$ 7.00 \quad \$ 60.00$ 10 to 12 inch $\ldots \ldots \ldots \ldots \ldots .15 \quad 1.50 \quad 4.00 \quad 10$ to 12 inch ............... $150 \quad 10.00 \quad 80.00$ 12 to 18 inch $\ldots \ldots \ldots \ldots \ldots .20 \quad 1.75 \quad 5.00 \quad 12$ to 18 inch $\ldots \ldots \ldots \ldots .25 \quad 12.00 \quad 100.00$

The special seedling offers below are strong, healthy trees.

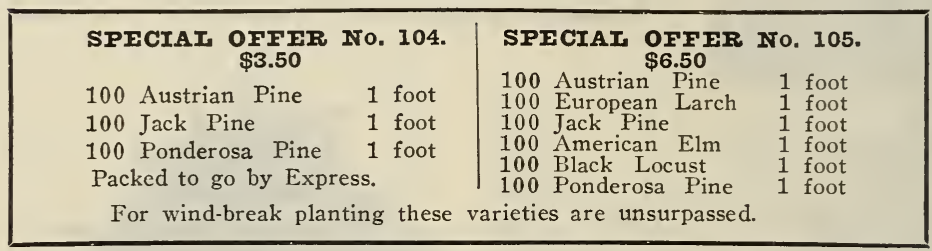

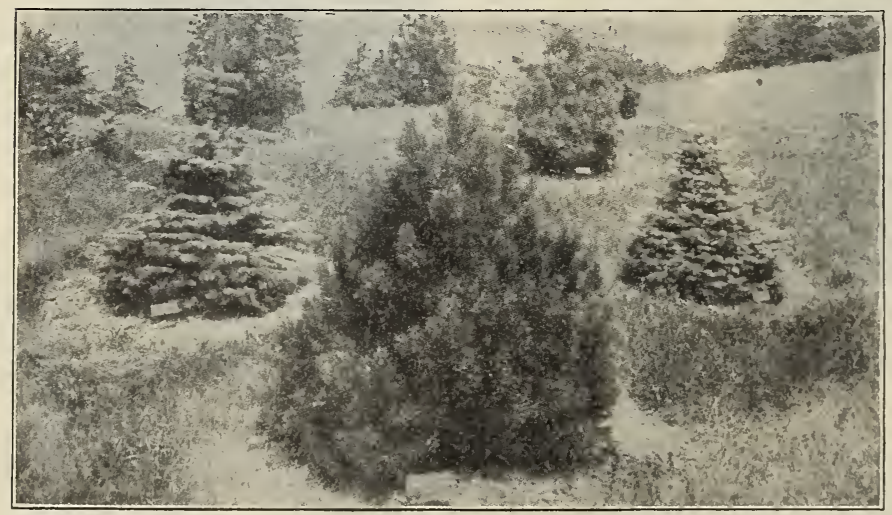

Dwarf IMountain Pine.

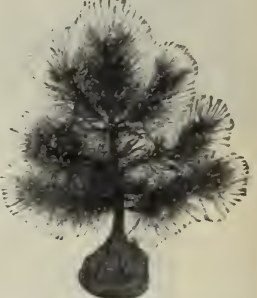

Ponderosa Pine.

\section{DWARF} MOUNTAIN PINE.

This beautiful, hardy little Fine is not excelled by any other tree when adaptability and usefulness is considered. Charming results are obtained from arranging Evergreens in ornamental groups, not alone for their individual attractiveness, but that the contrast of form and outline may create a charming aspect. How bright and cheery Evergreens look in the winter, when other trees and shrubs have lost their leaves and color. The Dwarf Mountain Pine grows to a height of ten feet and equally as broad.

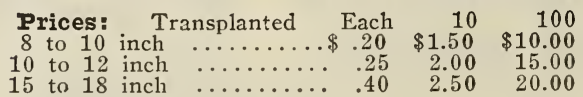

$\begin{array}{ccrr}\text { Transplanted } & \text { Each } & 10 & 100 \\ 11 / 2 \text { feet, select, 13. \& B. } \$ .60 & \$ 5.00 & \$ 40.00 \\ \text { Seedlings } & 100 & 1,000 & 10,000 \\ 3 \text { to } 5 \text { inch } \ldots \ldots \ldots \ldots+\$ 1.00 & \$ 8.00 & \$ 70.00\end{array}$

\section{DIRECTIONS FOR PLANTING WIND-BREAKS.}

In planting a wind-break, success depends to a great extent, upon the manner in which the ground is prepared to receive them. It should be carefully plowed or spaded as deeply as possible, and some rich compost or fertilizer added. If Seedlings are used plant them from one to three feet apart in the row and the rows ten feet apart, and thin out when they begin to crowd. If Transplanted trees are used, five feet apart in the row, and the rows ten feet apart, is a good distance.

Three rows ten feet apart, breaking joints, makes a very satisfactory wind-break. Plant the extra tall, fast growing varieties (Pines, Elm, Locust, Larch) in the row forming the outside, medium tall growers (Spruce) in the middle row, with the low growing trees (Arbor Vitæ, Cedars and Firs) to form the inside row. Hoe or cultivate thoroughly the first few summers after planting, especially during July, August and September.

I received the trees Saturday. They were in fine condition.-W. H. Wilson, North Branch, Mich. 


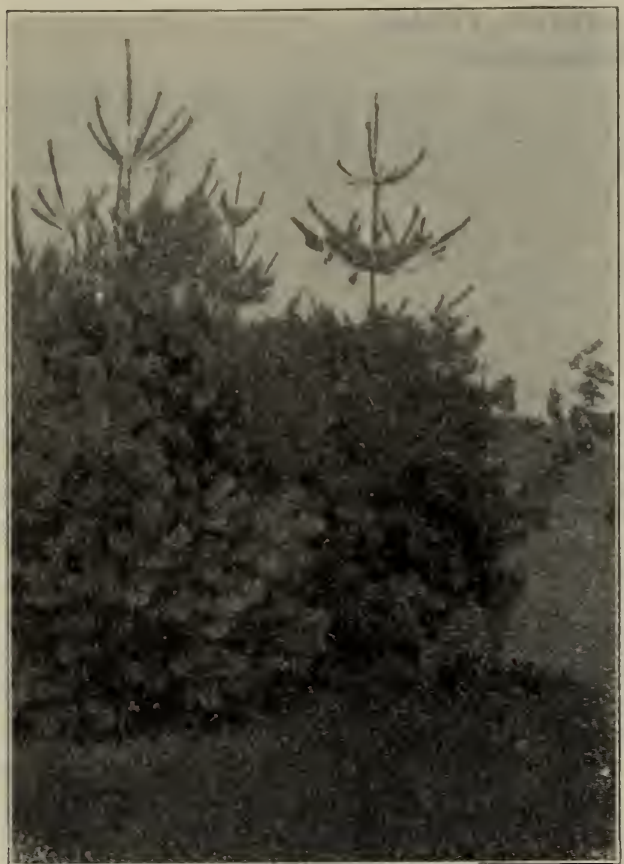

White Pine.

Prices: Transplanted Each $10,100 \quad 1,000$ 6 to 10 inch $\ldots \ldots . \$ .10 \$ .75 \$ 3.00 \$ 25.00$ 10 to 12 inch $\ldots \ldots \ldots . .15 \quad 1.00 \$ 4.00 \$ 35.00$

15 to 18 inch $\ldots \ldots \ldots .20 \quad 1.25 \quad 8.00 \quad 75.00$

18 to 24 inch $\ldots \ldots \ldots .25 \quad 2.00 \quad 15.00 \quad 155.00$
2 to 3 feet $\ldots \ldots \ldots . .35 \quad 3.00 \quad 20.00 \quad 175.00$

WHITE PINE.

The beauty of the White Pine is unsurpassed by any other Evergreen. Foliage long and soft; green, with a delicate tint of blue upon the under side of its needles. Its long, graceful, stately appearance places it at the top of the list. It can be planted in rows or arranged in formal groups, and if given plenty of room will grow and develop into handsome specimens. Sometimes they are planted close together to form a solid mass, and the effect is beautiful. White Pines are often used in planting an ornamental windbreak. In plantings of this nature the trees are arranged in informal groups or irregular rows, with plenty of space between each tree to develop and the most pleasing effects are thus obtained. Our White Pines after leaving seed beds are frequently transplanted from place to place in the Nursery, which of course produces well formed trees with an abundance of long fibrous roots, such trees as will live and grow to your entire satisfaction. The Dundee Nurseries specialize in White Pine, the seed beds of this variety alone cover an area of many acres. We grow them in all sizes from 4 to 6 inches up to 10 feet and can furnish them in any quantity, up to ten million plants.

WINDBREAT PIANTING. Mix White Pine with any of the other Evergreens for shelters, screens and wind-break plantings. They are such rapid growers, soon giving protection to the others. White Pines are extremely hardv, thriving in the cold climate of the far north. It adapts itself to all conditions and locations. Grows well on a poor soil and thrives in good ground. At maturity the White Pines are 100 feet tall, four feet in diameter. Grows so rapidly that several feet per season is ordinary, four feet is not unusual for a year's growth.

3 to 4 Transplanted feet $^{\text {Each }}$ \&......... $10.50 \$ 4.50 \$ 35.00$

5 to 6 feet, B. $\&$ B......... 1.25 11.00 100.00

6 to 7 feet, B. \& B......... $1.75 \quad 15.00 \quad 125.00$

7 to 8 feet, B. \& B.......

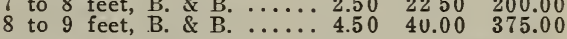

$\$ 1.00$ each; $\$ 8.00$ per $10 ; \$ 75.00$ per 100 .

Second Grade, for Mass Planting, 8 to 10 feet, $\$ 1.25$ each; $\$ 10.00$ per $10 ; \$ 90.00$ per 100 .

Seedlings
3 .

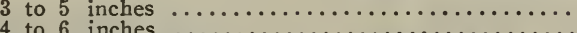

SCOTCH PINE. The old reliable Scotch Pine can be used for all purposes. Planted for ornament or wind-break and screens. It is a large tree with horizontal branches. Scotch Pines are hardy in any climate and one of the fastest growing of all Evergreens. Let us ship you some of our thrifty young plants.

Prices: Transplanted Eacli $10 \quad 100 \quad 1,000$

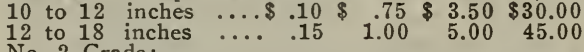

12 to 18 inch

$\begin{array}{cccc}\text { Seedlings } & 100 & 1,000 & 10,000\end{array}$

4 to 6 inches ..........\$1.00 \$5.00 \$45.00

6 to 8 inches $\ldots \ldots \ldots \ldots \ldots 1.25 \$ 8.00 \quad \$ 5.00$

8 to 10 inches $\ldots \ldots \ldots \ldots .1 .50 \quad 10.00 \quad 85.00$

FIEXIIIS PINE. A tree of medium size with stout horizontal branches; much used for lawn and ornamental planting.

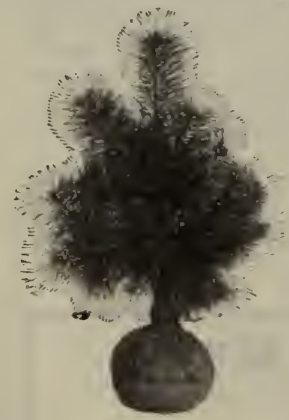

Flexilis Pine.

$\begin{array}{lrrrr}\text { Prices: } \quad \text { Seedlings } \quad 100 & 1,000 & 10,000 \\ 3 \text { to } 5 \text { inches } \ldots \ldots \ldots \ldots & \$ 1.50 & \$ 12.00 & \$ 110.00 \\ 4 \text { to } 6 \text { inches } \ldots \ldots \ldots \ldots & 2.00 & 15.00 & 140.00\end{array}$

EXCFISA PINE. A magnificent tree. The long, soft slender foliage is a most delicate tint of blue and stands out thickly from every branch. As a specimen plant on a nice lawn or park it is superb.

$\begin{array}{rccrr}\text { Prices: } & \text { Transplanted } & \text { Each } & 10 & 100 \\ 8 \text { to } 10 \text { inches } \ldots \ldots \ldots \ldots \ldots & .35 & \$ 2.00 & \$ 12.00 \\ 10 \text { to } 12 \text { inches } \ldots \ldots \ldots \ldots & .30 & 2.50 & 15.00 \\ 12 \text { to } 18 \text { inches } \ldots \ldots \ldots \ldots & .40 & 3.00 & 20.00\end{array}$

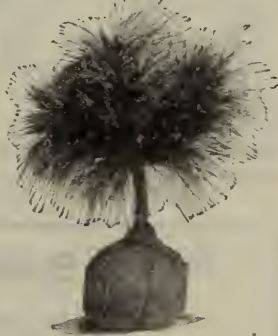

Excelsa Pine. 


\section{AMERICAN ARBOR VITAE. \\ (Thuya Occidentalis.)}

One of the bcst Evergreens for gcneral use. There is no Evergreen, either native or introduced, which will endure as much hardship, and grow on as great a variety of soils, under even adverse conditions, as the Arbor Vitæ. Owing to its regular habik of growth and ease with which it can be pruned and sheared, the Arbor Vitæ has become the most popular of all hedge plants, for which purpose it has no superior. (Hardy Hedge Plant Department, pages 37 to 39.)

\section{PEICE:}

$\begin{array}{rrrrrr}\text { Transplanted } & \text { Each } & 10 & 100 & 1,00 \\ 10 \text { to } 12 \text { inch } & \ldots \$ .10 & \$ 75 & \$ 4.00 & \$ 35.0 \\ 12 \text { to } 18 \text { inch } & \ldots & .15 & 1.00 & 5.50 & 50.0 \\ 18 \text { to } 24 \text { inch } & \cdots & .25 & 2.00 & 12.00 & 100.0 \\ 3 \text { to } 4 \text { feet } & \cdots & .50 & 3.50 & 30.00 & \\ 4 \text { to } 5 \text { feet } & \cdots & 75 & 6.00 & 50.00 & \end{array}$
Transplanted
Each
5 to 6 feet, B.\& B. $\$ 150$ \& 1250
8 to 10 feet, B. \& B. $\$ 5.00 \quad 45.00$

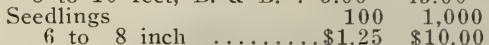
6 to 8 inch $\ldots \ldots \ldots \ldots 1.25 \quad \$ 10.00$

100

$\$ 120.00$ 50.00

4 to 5 feet $\quad .75-6.00-50.00$

\section{SIBERIAN ARBOR VITAE.}

\section{(Thuya Siberica.)}

The Siberian Arbor Vitæ has a dense foliage of a darker shade of green than that of the Americar, and in form the tree is also conical, but wider at the base. 1 t retains its color well throughout the winter, and is an elegant specimen tree of the greatest hardiness.

\section{PRICY:}

Transplanted

8 to 12 inch

$\begin{array}{rrr}\text { Each } & 10 & 100 \\ \ldots . . . \$ .20 & \$ 1.50 & \$ 12.00\end{array}$

Transplanted

12 to 15 inch

$\begin{array}{rr}\text { Each } & 10 \\ \$ .25 & \$ 2.00\end{array}$

100

10,000

$\$ 90.00$

\section{PYRAMIDAL ARBOR VITAE. \\ (Thuya Pyramidalis.)}

Forms an elegant and very slender shaft of dark green. This variety is one of the hardiest and can be used in the formation of a very handsome ornamental hedge or screen. Cannot be too highly recommended for lawn and garden planting.

\section{PRICE :}

Transplanted

10 to 12 inch $\ldots \$ .15 \quad \$ 1.25 \quad \$ 9.00$

12 to 15 inch $\ldots \quad .25 \quad 2.00 \quad 12.00$

1,000

Transplanted

Each $\quad 10 \quad 100$

B. $\ldots 1.00 \quad \$ 9.00 \quad \$ 85.00$

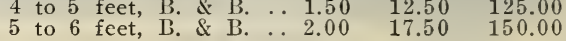
100.00

R VITAE.

\section{CHINESE ARBOR VITA}

The Chinese Arbor Vitæ are an important group of elegant Evergreens in which are embodied a great diversity of color and texture in foliage as well as variety in type and outline of tree. In their numerous shades of green and gold they afford some of the finest material for the formation of groups and bods of Evergreens and are unexcelled as specimen trees in the South and Western States where the winters are less severe than in the Northern States.

\section{PRICE:}

Seedlings

4 to 6 inch

$\begin{array}{rrr}100 & 1,000 & 10,000 \\ \ldots . . . \% \$ 1.00 & \$ 7.00 & \$ 60.00\end{array}$

\section{0}

Seedlings

8 to 10 inch

10 to 12 inch
1,000 $\$ 10.00 \$ 80.00$ $\$ 10.00 \$ 80.00$

\section{PLANTING AND CARE OF EVERGREENS.}

The best results are sccured by transplanting Evergreens in the Spring, especially is this true of the smaller sizes. However, Fall planting, if properly done, is attended with small loss. Do not let the roots become dry or be exposed to the wind and sun, and if the wcathcr is dry, dip the roots in water before planting. The size of the hole will depend upon the size of the tree to be planted, and it should be large enough to hold the clump of roots without crowding. If it occurs in digging that the surface soil is of better quality than that found further down, as frequently happens, put a small quantity of this to one side and replace it in the hole before the tree is inserted. After adjusting the roots in the hole as nearly as possible in the position which they formerly occupied, fill the earth in gently and thoroughly around them, packing the soil firmly with the ball of your foot. As a finishing process, after filling the hole and firming the soil well about the tree, apply as a mulch, several inches of rotted straw, coarse manure or grass. Too much emphasis can scarcely be laid upon the importance of this last step. With shade, fruit, and ornamental trees it is possiblc to preserve a bance bctween top and roots by cutting back the former if the latter be injured, but this is not practical in dealing with Evergreens. To protect the roots against drying by exposure to sun and wind they must be carefully wrapped in a wet sack, piece of burlap or old cloth, even if moved for only a short distance. If the soil is poor the trees will be benefited by having thoroughly rotted manurc spaded into the carth about them, but this must not come into dircct contact witl the roots. mand fresh manure ought never to be used. Evergreens should be watered well during the months of July and August, as at that time they make new roots, and consequently need lots of moisture. When dug with ball of carth and burlapped the loss should not excced onc per cent.

\section{Special Offer No. 106}




\section{SAVE MONEY BY PLANTING TREES.}

Evergrecns are of great value both for slelter and ornanicnt. At all times they furnish a barrier to wind and cold, and the remarkably picturesque forms assumed by mature specimens of many species add much to the attractiveness of a country home, especially when their boughs gracefully bend beneath a load of snow. In winter when other trees are destitute of foliage, these majestic trees lend to the scene an air of animation, which moderates in a large measure the sevcrity and dcsolation of the season. If tastefully intermingled with other trees and shrubs about the home they give warmth of verdure and variety of outline unattainable without their use. That many of the Evergreens can be successfully grown upon poor, barren or sandy soils is an additional argument in their favor.

WIND-BREAKS, SHFLTER-BEITS AND SCREENS. Every country lome should have its shelter belt of Evergrcens. Wind-breaks are not meant for the sole use of extensive orchardists as was once thought, but should be so commonly planted as to protect cvery home exposcd in the least to the ravages of wind and storm. The saving in fuel alone will defray the cost of planting material in a few years' time; nor need one wait a dozcn years or cven lialf so long for Evergreens to grow large enough to afford a protection against piercing winds. Results may be secured in a comparatively short time by planting quite thickly, the superfluous trees to be removed from time to time as they encroach upon those which it is designed to leave for permanent shelter. Many an cxposed barnyard, poultry run or apiary might be transformed into a place of genuine comfort for its inmates on wintry days, by planting along its Northern and Western sides a row of White Pine, Norway Spruce or Arbor Vitæ.

A MIXED PLANTING. Often a wind-break can be worked into general landscape cffect to break up the monotony. This is done by informal groupings and combining different shades of color. Then an irregular shelter belt of Evergreens becomes, with Maples, Birches, and other trees, a charming addition to the landscape.

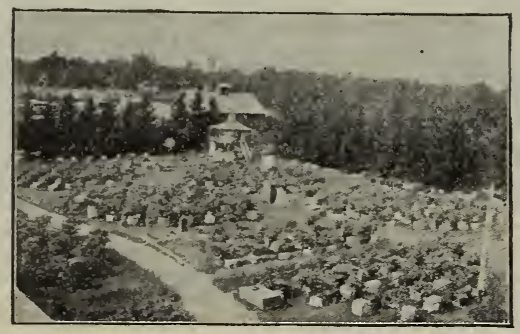

This is a partial view of the apiary of the A. I. Root Company, Medina, Ohio. These Evergreens were planted in 1879 as a wind-break, all around the apiary. They are very thrifty. Now they average 40 feet in height. Says Mr. Root, "In a few years more their branches will be tightly interwoven; a more solid and lasting phalanx could hardly be desired as a wind-break."

\section{PLANT CHRISTMAS TREES. PROFIT \$839.00 PER ACRE.}

Every farmer has an acre of ground somewhere on his farm that isn't bringing him in a cent; perhaps it is a cut-over wood-lot, or a little corner somewhere hard to get at, or ground that is worn out for corn and farm crops. This land will grow Christmas trees. This is a great opportunity to make big profits. You can easily dispose of all the Christmas trees you raise either to your surrounding towns or by shipping to the large cities. The demand is now far in excess of the supply. You won't have to look for buyers-the buyers will look for you. Christmas trees in 500 to 1,000 lots sell for the following prices, in smaller quantities just about double. 3 feet ligh, 20 cents each. 4 feet high, 30 cents. 5 feet high, 45 cents. 6 feet high, 65 cents. 7 feet high, 75 cents to $\$ 1.00$

ONIY TWO DAYS' WORK TO PLANT AN ACRE OF CHRISTMAS TREFS. Plow the ground in the Fall and again in the Spring after it has become warm and mellow. Stretch a linc across the field and plant in straight rows. To plant the trees simply press the spade into the ground and work it back and forth until the opening is large enough to admit the roots of the tree. Place the roots in the opening and press the soil firmly about same with ball of the foot. Plant the trees three feet apart in rows and the rows three feet apart. Cultivate the ground with corn cultivator several times during the season for two years. After the first year these Spruces will grow from six to eighteen inches for two years, after that the average growth per year will be from one to two feet. Cut away every other tree when three or four feet in height. Planting the above distance apart an acre will hold 4,840 trees.

One man and two boys can plant the trees in two days. The first trees will be ready to cut in five years, when they will be an average height of 3 to 4 feet. Figure a ten per cent loss, which will give you 3,356 salable trees at $\$ 250.00$ per 1,000 or a total return if sold the first year of $\$ 839.00$ for just one acre. If kept one or two years longer their increased growth would just about double the returns. This is not a special case, but a very low, conservative estimate of what any ordinary man on ordinary land, with very little work or expense, could do. We are growing for this year's shipments alone, 2,000,000 Norway Spruce.

\section{Special Xmas Tree Offer No. 107}

4,900 Norway Spruce select seedlings, 10 to 12 inch, for Christmas tree planting.

\section{Price $\$ 53.90$.}

\section{Special Windbreak Offer No. 108}

100 Ponderosa Pine, 1 foot

100 Austrian Pine, 1 foot

100 Norway Spruce, 1 foot

All fine, heavy TRANSPLANTED trees.
50 Black Locust, $11 / 2$ to 2 feet

50 American Elm, 2 to 2 f 2 feet feet Price $\$ 13.50$.

To reliable parties we will furnish fifty to one hundred thousand Spruces to plant on shares for Christmas trees. 


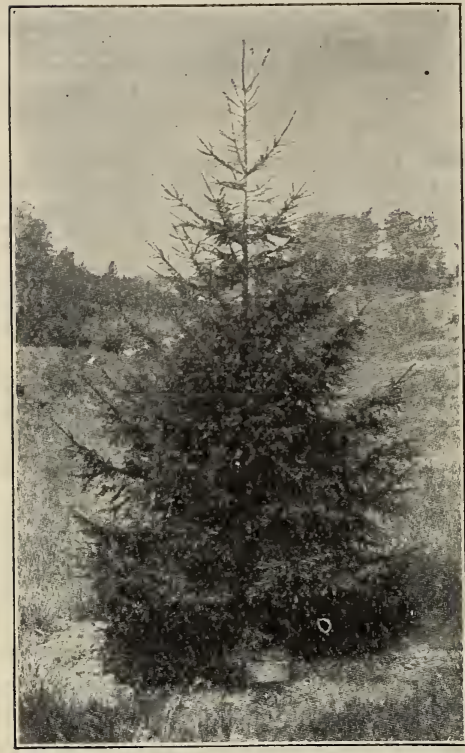

Norway Spruce.

Prices:

$\begin{array}{rrrrr}\text { Transplanted } & \text { Each } & 10 & 100 & 1,000 \\ 10 \text { to } 12 \text { inch } \ldots \$ .20 & \$ 1.00 & \$ 5.00 & \$ 45.00 \\ 12 \text { to } 15 \text { inch } \ldots .25 & 2.00 & 7.00 & 65.00 \\ 18 \text { to } 24 \text { inch } \ldots .40 & 3.00 & 15.00 & 125.00 \\ 2 \text { to } 3 \text { feet } \ldots .50 & 3.50 & 25.00 & 200.00 \\ 3 \text { to } 4 \text { feet } \ldots .65 & 5.00 & 40.00 & \\ 4 \text { to } 5 \text { ft., B. \& B. } 1.25 & 10.00 & 90.00 & \\ 4 \text { Seedlings } & 100 & 1,000 & 10,000 \\ 4 \text { to } 6 \text { inch } \ldots \ldots \ldots \ldots . \$ 1.25 & \$ 12.00 & \$ 100.00 \\ 6 \text { to } 8 \text { inch } \ldots \ldots \ldots \ldots .2 .00 & 15.00 & \end{array}$

BIACK FIII SPRUCE. No Evergreen is more beautiful than the round, compact, evenly-branched Black Hill Spruce, with attractive foliage at all seasons. No tree adapts itself more readily to conditions than this one. A tree unsurpassed in beauty and at the same time one with a most rugged constitution. Is absolutely the hardiest of all Spruces. IVe recommend this variety very highly and know that you will be delighted with this beautiful bushy, compact Evergreen; every one a specimen. Even the little fellows are stocky and compact. The larger sizes are dug with ball of earth and burlapped, and when handled in this manner they never show the effects of replanting, but put on a good growth the first year.

\begin{tabular}{|c|c|c|c|c|c|c|}
\hline \multicolumn{2}{|c|}{ Prices: } & Transplanted & Each & 10 & 100 & 1,000 \\
\hline & to $12 \mathrm{inch}$ & ............ & & $\$ 1.50$ & $\$ 8.00$ & $\$ 70.00$ \\
\hline 15 & to 18 inch & & .30 & 2.00 & 12.00 & \\
\hline 18 & to 24 inch & & .40 & 3.50 & 20.00 & \\
\hline & to 3 feet & & .75 & 6.00 & 50.00 & \\
\hline & to 4 feet, & $B \& B$ & 1.00 & 9.00 & 80.00 & \\
\hline & to 5 feet, & $B \& B$ & .2 .00 & 17.50 & & \\
\hline
\end{tabular}
growth.

NORWAY SPRUCE. In describing the Norway Spruce which has been so abundantly and widely planted with the fact that it readily adapts itself to almost any soil, this variety has become a general favorite. There is cannot be found in abundance. It is valuable for planting in parks, cemeteries and lawns, while its extremely rapid habit of growth recommend it as especially valuable where speedy results are desired. Plant this anywhere in the growth forms an almost impenetrable barrier to the sharp winds and frosts that cause great damage to fruit and

10 to 12 inch $\ldots \ldots \ldots \ldots \$ .12 \quad \$ 1.00 \quad \$ 4.00 \quad \$ 30.00$

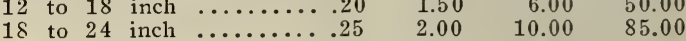

2 to 3 feet $\ldots \ldots \ldots \ldots .35 \quad 3.00 \quad 20.00$.

Seedlings $\quad 100 \quad 1,000$

4 to 6 inch $\ldots \ldots \ldots \ldots \ldots \ldots \ldots 1.00$ \$ 4.50 \$ 40.00

6
0 to 12 inch $\ldots \ldots \ldots \ldots \ldots \ldots \ldots \ldots \ldots \ldots \ldots$

WHITE SPRUCE. Another of the true native Amerfor wind-break and ornamental planting. We recommend northern portions of the United States and all over Canada. It is hardy in any climate. Of all the spruces native of America, White Spruce is one of the most attractive, on 
Many of the most beautiful Evergreens cannot be grown from seed. Some come from distant foreign lands, and their seeds cannot be obtained, others give no seeds. The demand for these beautiful fancy sorts has grown each year, until it takes our best efforts to grow enough of this stock to go around. These choice varieties are all grown from grafts, under glass. We have our own expert conifer specialists, who do this delicate work. The plants are carefully grown, always under the watchful eye of the graftsman, who cuts and trims and trains each tree into proper form. Hill's Grafted Evergreens are choice, not alone in form, but in quality. Some are decked in gorgeous colors, some have a peculiar delicate shade, while others have a graceful and drooping habit. Our stock consists of over one hundred varieties and we desire to call your attention to the fact that all are hardy. After they come from the grafting houses they are planted to the open ground, here again they receive special care and attention that each tree may form a perfect specimen.

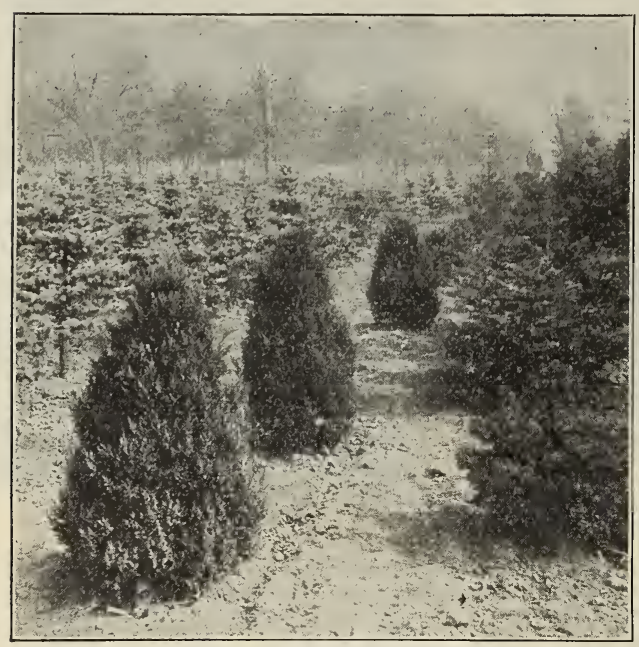

White Tipped Juniper.

JUNIPFRUS PFITZERIANA. This is the latest of the new Junipers added to our list and is entirely different from all the other forms. It is a peculiar form having thread or whip-like branches. Matures into a bushy tree from which stiffness and formality are wholly lacking. Vigorous growing and hardy.

Prices: Transplanted Each

2 feet, B. \& B. ............... \$2.50

10

$\$ 22.50$

JUNIPERUS GIAUCA. This is the attractive and showy Silver Blue Cedar. A grafted tree of the most beautiful type. This is perhaps the best known of all fancy Junipers, being now widely planted throughout the United States, in all ornamental, lawn and garden plantings. Too many good things cannot be said of its beauty and sterling qualities. This beautiful silver blue shade comes only in the grafted trees, and do not forget that in buying these choice grafted varieties, you are certain to obtain uniformity in color and form. What a source of satisfaction it is to purchase a dozen choice Junipers and receive trees of a uniform type, each and every one having the same delicate silvery blue foliage growing to the same clean upright form.

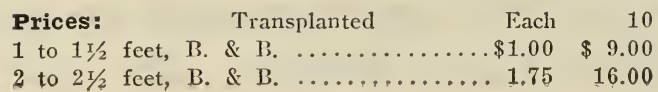

WHITE TIPPED JUNIPER. A most beautiful upright growing variety. Matures at 12 to 15 feet in height always retaining its pyramidal form. Derse dark green foliage, tipped with pure white tips, which gives the plant a most attractive appcarance.

Prices: Transplanted Each 10 $21 / 2$ to 3 feet, B. \& B. ..... \$2.00 $\$ 19.00$ 1 foot, B. \& B. ..... $1.00 \quad 9.00$

JUIIPERUS SINERSIS. A hardy robust Juniper from Japan. Grown to pyramidal form, foliage of a bright fresh green.

Frices: Transplanted Each 10 1 foot, B. \& B. ..... \$.90 \$ 7.50 $21 / 2$ to 3 feet, B. \& B. ..... $2.00 \quad 19.00$

JUNIPERUS SCHOTTY. A beautiful columnar tree first discovered and propagated in German nurseries. Always of pyramidal growth, presenting a most charming aspect.

Prices: Transplanted Each 10 1 to $11 / 2$ feet, B. \& B. . . . . $\$ 1.00 \$ 9.00$ 2 to $2 \frac{1}{2}$ feet, B. \& B. ...... $1.50 \quad 14.00$

JUNIPERUS EIEGANTISSIMA IEE.

A beautiful dark green pyramidal Cedar with bright golden tips. We recommend it as excellent for lawn planting.

Prices: Transplanted Each 10 1 to $1 \frac{1}{2}$ feet, B. \& B. .... $\$ 1.00 \$ 9.00$ 2 to $2 \frac{1}{2}$ feet, B. \& B. ..... $1.75 \quad 16.00$

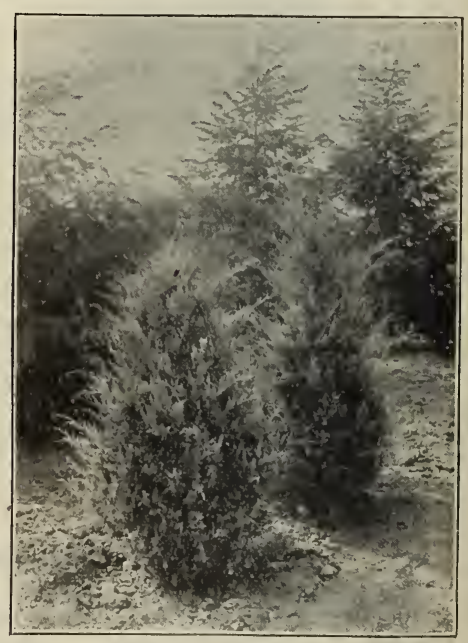

Juniperus Glauca, 


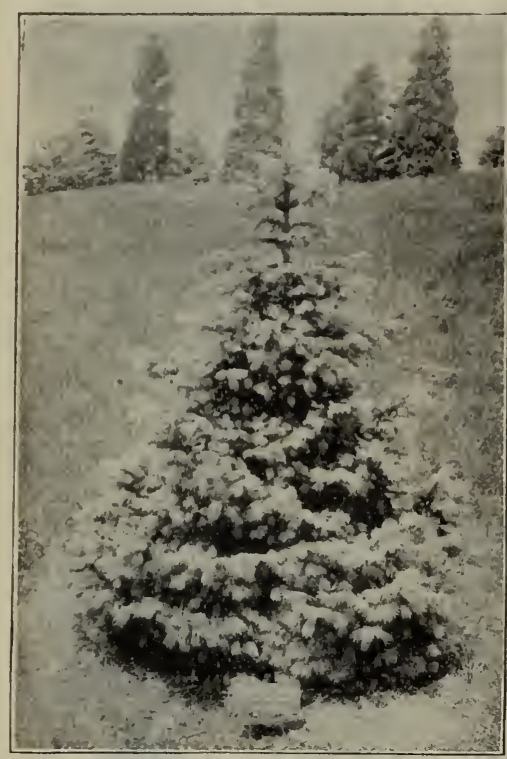

Engleman Spruce (Glauca).
JUNIPERUS PROCUMBENS. A remarkably beautiful dwarf Evergreen growing always close to the ground. A most valuable Evergreen for ornamental planting. This is the best of all dwarf or prostrate growing Evergreens. We recommend it as being especially well adapted for cemetery planting.

Prices: Transplanted Each 10 1 foot, B. \& B. ................. \$1.50 \$14.00 2 feet, B. \& B. ................. $2.50 \quad 23.00$

JUNIPERUS JAPONICA AUREA. The pretty little bright golden dwarf Juniper, creeping over the ground, pushing forward its delicate golden branches in every direction, finally covering an area four feet wide. Hardy and immensely attractive.

Prices: Transplanted Each 10 1 foot, B. \& B. ................... \$1.00 \$ 9.00

FNGIFMAN SPRUCE (Glauca). A fine new grafted Spruce, and one of the most beautiful grown in our Nurseries. A place should be made for one upon every lawn. Is entirely hardy and grows to large size. Engleman's Glaucas are all grafted plants, with foliage of pronounced glauca green. This is the most symmetrical grower of all Spruces, always straight and evenly branched, and where a single specimen is desired, planted for its beauty alone, we cannot recommend a more perfect tree than this.

Prices: Transplanted Each 10 $1 \mathrm{r} / 2$ to 2 feet, B. \& B. ............. \$2.50 $\$ 23.00$

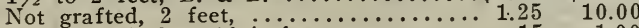

Not grafted, 6 to 10 inches, ............ $15 \quad 1.00$

AICOCK'S SPRUCE. Sir Alcock's Spruce. A rare and beautiful Spruce from the mountains of Japan. Fine compact growing tree of rare beauty on account of its peculiar foliage, which is pale green above and bright blue beneath. Alcock's Spruce develops into fine specimens.
Prices:
Transplanted
Eacl
$\vdots 0$
$\vdots$
Transplanted
$\begin{array}{rr}\text { Each } & 10 \\ \$ 3.00 & \$ 27.50\end{array}$

PICEA OMORIKA. Sometimes called Servian Spruce. A remarkably distinct and ornamental tree of dense and narrow outline.

Prices:

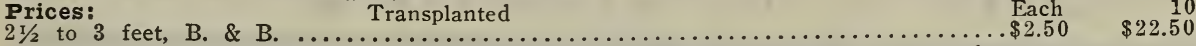

ORIENTAI SPRUCE. A fine large growing Spruce. Foliage dark green, hardy and of rapid growth, growing round and bushy.

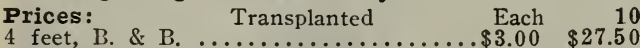

WEEPING NORWAY SPRUCE. A most striking and useful Evergreen tree, growing to large size while the branches grow always in a drooping position, growing straight down and finally spread out gracefully upon the ground around the base of the tree. This is always a popular tree. We sell them in quantities every
year, and it is much used for cemetery planting for which purpose it is well adapted; always growing pyramidal in form and requires little space. The Weeping Norway Spruce is robust and hardy, not affected by the most severe winter weather, adapting itself to soils and conditions very readily. WVe are continually talking quality; Hill's Evergreens have half a century's record built upon the strong foundation of QUALITY. No other firm will furnish trees of equal quality at lower prices. No other Nurserymen can furnisl better quality at any price.

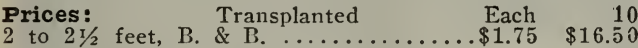

\section{Hill's Tri-Color Collection}

\section{Price $\$ 4.00$}

All select transplanted trees.

1 Juniperus Sinensis, ......1 foot

1 White Tipped Juniper, $\ldots 1$ foot

1 Juniperus Glauca, .......1 foot

1 Juniperus Elegants Lee, ..1 foot

2 Engleman Spruce, ......10 inches

1 Grafted Blue Spruce, ....1 foot

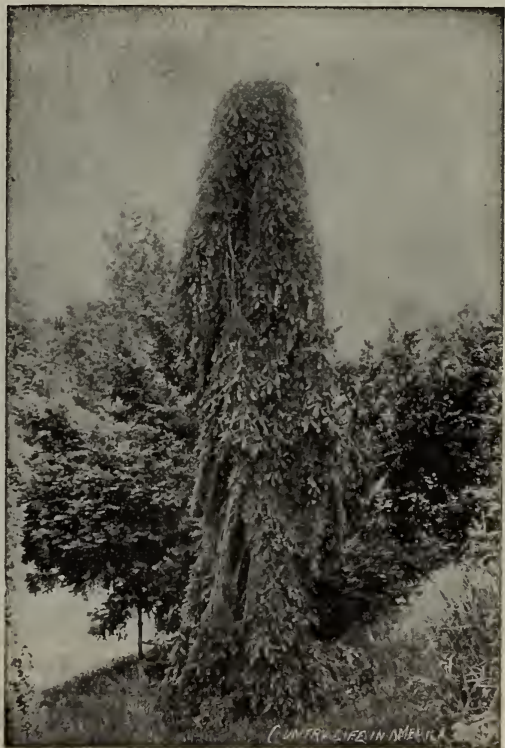

Weeping INorway Spruce. 
ABIFS VEITHCI GIAUCA. A rare and magnificent tree of remarkably symmetrical habit, naturally forming a perfect pyramid. This beautiful tree is native of the mountains of Japan, where it develops into grand specimens. It is impossible to describe the beauties of this most beautiful of all Firs. People are simply amazed at its grandeur. Foliage of pale green above and most vivid sparkling blue beneath. The needles stand straight out from the branches and flashes of blue are always to be seen.

Prices: Transplanted $\quad$ Each 10

2 to $21 / 2$ feet, B. \& B. ......... \$2.00 $\$ 10.00$

1 foot, B. \& B......... Each $\begin{array}{rr}\text { Transplanted } & 10 \\ 1.00 & \$ 9.00\end{array}$

ABIFS PINSAPO GIAUCA. A Fir in blue. A beautiful soft shade, almost as blue as the Blue Spruce. Its needles are short and grow straight out from the wood on all sides. This tree grows only to medium size, maturing at 16 to 20 feet. Tapering in form, growing always round and pyramidal. We have some extra fine Pinsapo Glaucas, which we ship with ball of earth about their roots.

Prices: Transplanted Each 10

Transplanted Each 10

$1 / 2$ to 3 feet, B. \& B. ......... $\$ 2.00 \$ 17.50$

PEABODY'S GOLDIN ARBOR VITF Few Evergreens are more attractive for lawn and ornamental planting than this beautiful Golden Arbor Vitæ. Grows to neat pyramidal form, thrives upon any soil and is perfectly hardy.

$\begin{array}{llr}\text { Prices: } & \text { Transplanted } \quad \text { Each } & 10 \\ 2 \text { to } 3 & \text { feet, B. \& B. ........... } \$ 1.75 & \$ 15.00\end{array}$

3 to $31 / 2$ feet, B. \& B. .......... 2.25 20.00

EIEGANTS ARBOR VITE. Bright green with golden tips, growing pyramidal in form and always neat and attractive.

Prices: Transplanted Each 10 2 to $2 \frac{1}{2}$ feet, B. \& B. .........\$1.25 \$10.00

GOIDEN STBERIAN ARBOR VITAE. is another of the beautiful golden trees, but of a soft, golden hue, retaining its perfect color throughout the entire year.

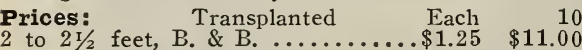

TOM THUMB. An exceedingly attractive Evergreen growing to fine globe form. Can be sheared into any desired shape.

Prices:

2 to $21 / 2$ feet, B. \& B. ......... $\$ .75 \quad \$ 7.00$

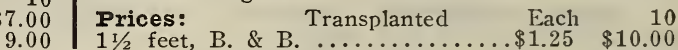

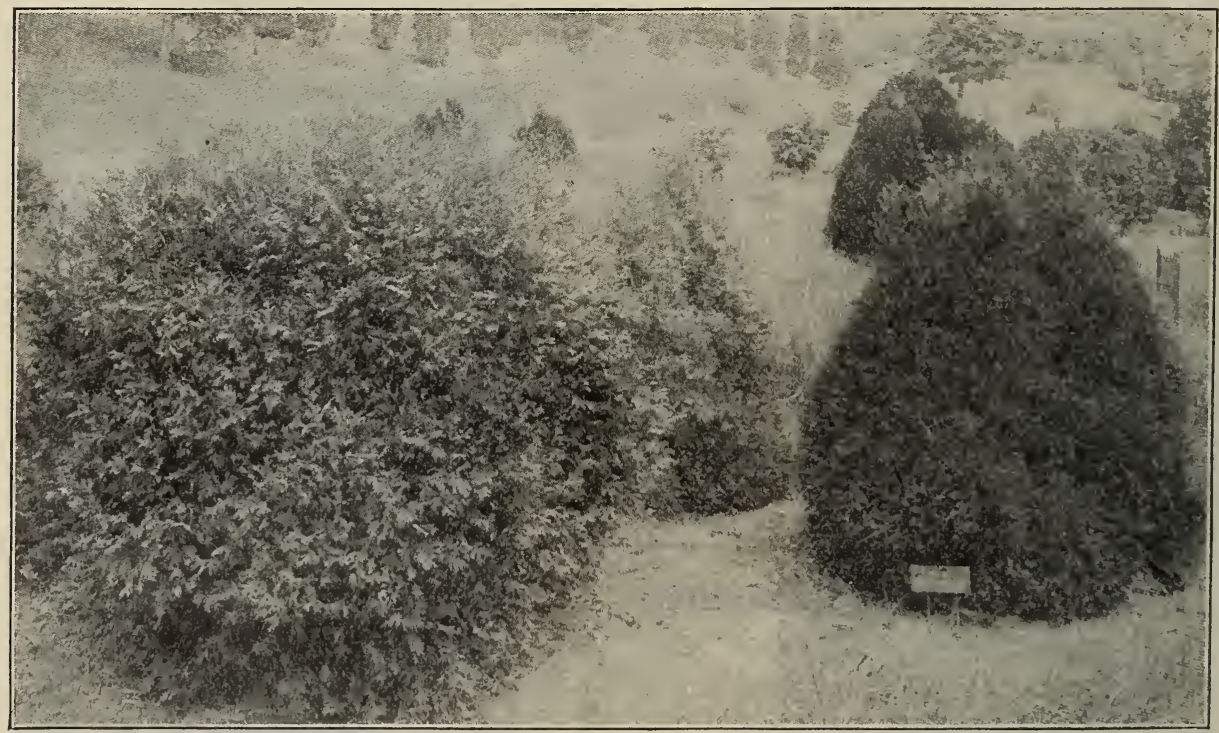

Hoovey's Golden Arbor vitæ.

Tom Thumb.
HOOVEY'S GOLDEN. Fine dwarf golden

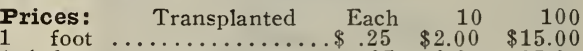

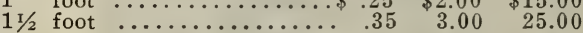

CANADIAN YEW. A rare and useful little evergreen, growing dwarf or sheared to any desired form. This hardy little tree. Grows best in partial shade. Covered in summer with bright red ber-

Prices: Transplanted

10 to 12 inch $\$ .35 \quad \$ 3.0 \mathrm{U}$ to 18 inch .75

B \& B

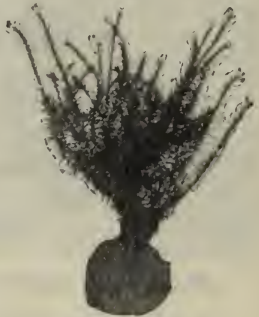

Canadian Yew.

JAPANBSE YrW. A beautiful variety from Japan, having strong upright habit of growth. Thrives in either sun or shade, covered in sumTher with bright scarlet fruit berries.

$1 / 2$ feet, B. \& B. ............ \$1.25 $\$ 10.00$ yew is a most valuable

\section{Special Offer No. 110, $\$ 1.00$, Postpaid.}

2 Blue Spruce, 6 inches

2 Peabody's Golden Arbor Vitx, 2 years
3 Engleman Spruce, 6 inches

3 Dwarf Mountain Pine, 6 inches 


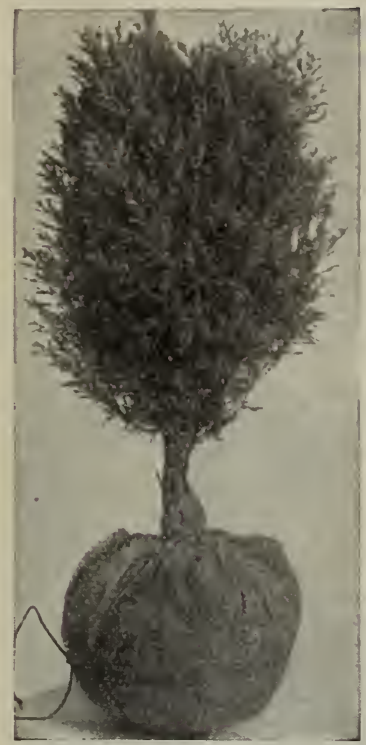

Rosedale Hybrid.
ROSEDAIE HYBRID. This is one of the most attractive Evergreens we offer. It is thought to have originated from a cross between the Tom Thumb Arbor l'itx and the Japanese Cypress. Recommended for the southern and southwestern States.

Prices: $\quad$ Transplanted Each 10

1 to $11 / 2$ feet, B. \& B. . . . . . . . . . . . . . . \$ .50 \$4.00

2 feet, B. \& B. ................... .75 7.00

RETINOSPORA PIUMOSA. Sometimes called Japanese Cypress, is the beautiful green variety growing to elegant form, much branched and very bushy. The foliage is delicate, feathery and fern-like. Responds very readily to shearing and can be grown to any desired shape, but the most attractive form is a natural globe shape, wide at the base, tapering at the top. No Evergreen is more beautiful for the lawn and ornamental planting, also much used for growing in tubs. We have fine plants all of which have been carefully grown to perfect form.

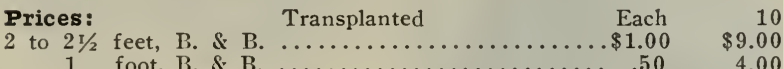

GOIDEN RETINOSPORA PIUMOSA. Grows to the same attractive form as the Green Retinospora, but clothed in a mass of gorgeous golden foliage, so dainty and attractive that it adds beauty and splendor to its entire surroundings. We advise planting the green and golden varieties side by side, to produce the most inspiring effect. Plant them in rich soil, they thrive best in fertile ground.

Prices: $\quad$ Transplanted $\quad$ Each 10

2 to $21 / 2$ feet, B. \& B. .......................... $\$ 1.25 \quad \$ 11.00$

1 foot, B. \& B. .................. .70 6.00

SWISS STONE PINE. The Swiss Stone Pine is a medium growing specie, originally found upon the mountains of Central Europe. Specimens attain twenty-five feet in height. It is a beautiful pine with compact habit, which together with its dense dark green foliage and assured hardiness make it a tree of great service in ornamental planting. It is especially attractive when planted as a single specimen. It is also an especially hardy Evergreen and thrives on any soil, and is without question one of the most beautiful and attractive of all pines.

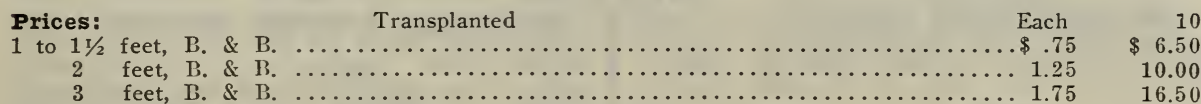

THE BEAUTIFUI ChINESE ARBOR VITF. These grand specimens are the true pyramidal type, growing clean, straight and.upright in form. This variety is one of the best for the formation of a very handsome ornamental group or screen. We do not recommend planting this tree north of southern Illinois.

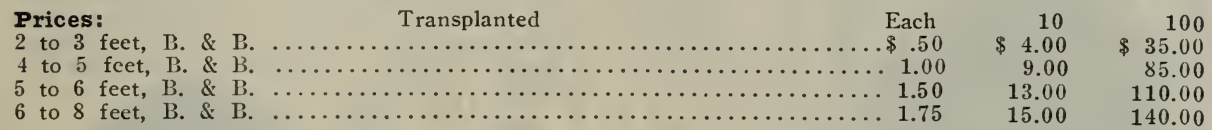

Plant beautiful Evergreens because of their enduring foliage. They should be more extensively planted about town, city and country homes, whether used in straight rows, wind-breaks or mingled informally with other trees on the lawn.

\section{Special Offer No. 111 $\$ 4.55$.}

12 Norway Spruce, fine transplanted, 1 foot.

12 White Pine, select transplanted, 1 foot.

3 Dwarf Mountain Pine, fine transplanted, 1 foot.

2 Engleman Spruce, fine transplanted, 10 inches.

1 Abies Veitchi, fine transplanted, 1 foot.

1 Golden Retinospora, fine transplanted, 1 foot.

6 Beautiful Hardy Flowering Shrubs, (our selection), for lawn planting, 3 varieties, 1 to 2 feet.
Our big specimen Evergreens are all carefully grown and can be planted for immediate effect. Hill's Beauamong planters. Wig ship several thousand each year, ranging from 6 to 12 feet tall, all big, round, bushy specimens. These trees are all several times transplanted and grown to perfection in every respect. We have had unlimited experience in handling big Evergree.1s, shipping in large quantities, and often not a single tree has failed out of an entire lot. All big trees are dug with good balls of earth and securely tied in burlap.

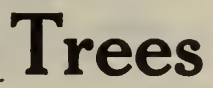




\section{Shade and Ornamental Tree Department.}

This departmcnt includes trees of varieties which drop thcir leaves in winter. We have always given this department of our business particular attention. The wide range in selection afforded the planter in choosing from the ranks of deciduous trees constitutes one of the charms of this very important group. No garden or landscape is complete without them. Hlant a few of these on the lawn, door yard or tree bank and you will be surprised how they will increase the value and beautify your home. "These trees arc select straight specimens and fully, uphold the reputation of all "Dundee Grown" stock. We are enabled to sell "GOOD TREES" cheap because we grow them in such large quantities.

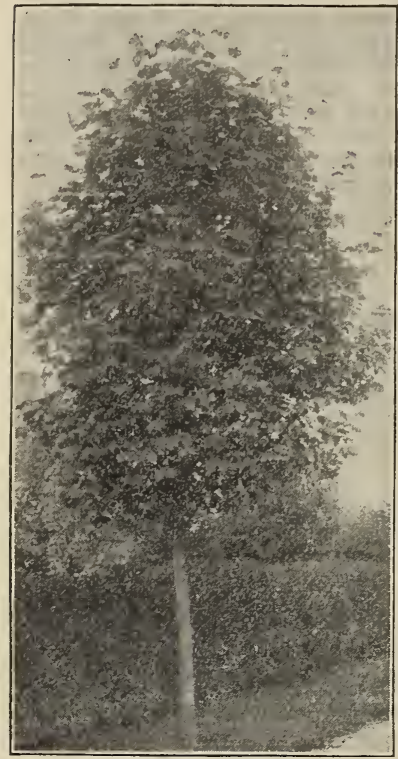

Norway Iraple.

\section{MAPLES.}

One of the most widely known class of trees and the most valuable. We offer four varieties of Maples. For grace of form, beauty of foliagc, and grateful shade no tree can excel the Maple, and the purple-leaved varieties are simply superb. in all cases where diameter is given the tree is measured one foot above ground. Value for money received is our watchword.

NORWAY IMAPIE. Handsome round headed trees, and excellent for lawn, tree banks, etc., where a spreading tree is wanted. Medium fast growers with broad green leaves which

turn pale yellow in Autumn. (See illustration.) 10$$
4 \text { to } 5 \text { feet }
$$
$\$ .15$

5 to 6 feet .120

1 inch diameter

1 to $11 / 2$ inch diameter ............. 75

$11 / 2$ inch diameter up

1.25

$\$ \begin{array}{r}10 \\ 1.25 \\ 1.50\end{array}$

$\$ 10.00$ 12.00

$5.00 \quad 45.00$

7.00
1.00 60

Slow in growth, but becoming one of the grandest of shade trees. Foliage turns bright yellow and scarlet in Fall. It is the sap of this tree which makes the well-known Maple Sugar. Prices: Each $10 \quad 100$ 6 to 8 feet $\ldots \ldots \ldots \ldots \ldots \ldots \ldots \ldots .50 \quad \$ 4.00 \quad \$ 30.00$

1 inch diameter, …… SCHWIDIER'S PURPIE IEAF MAPIE. One of
he grandest of the Maples. Foliage bright crimson in early Spring, changing to purplish green in the Fall. A beautiful tree for the lawn. Its foliage contrasts strikingly against the Norway or Hard iraple.

\begin{tabular}{|c|c|}
\hline Prices: & Each \\
\hline 6 to 7 feet high & \\
\hline
\end{tabular}

RITTENBACF'S MAFII. A beautiful variety of the Maple family. Grows strong and upright. Its foliage is bright green in Spring, but turns a rich purple towards Autumn.

Frice: 2 inch diameter, each, ............... $\$ 2.50$

\section{WILLOWS.}

GOIDEN BARIED WIIIOW. The bright golden bark of this variety makes it strikingly attractive, especially in the winter. It makes a very pretty tree with its graceful, drooping branches.

6 to 8 feet $\ldots \ldots \ldots \ldots \ldots \ldots \ldots \$ .65$

8 to 10 feet

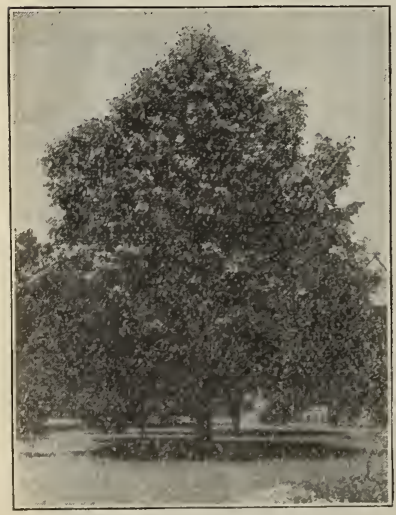

American Iinden

WISCONSIN WEEPING WIIIOW. This variety grows rather low with flat head and very crooked trunk. The leaves are bluish underneath. It is easy to grow and sure to give satis Prices:
6 to feet $\ldots \ldots \ldots \ldots \ldots \ldots \$ .75 \quad \$ 7.00$

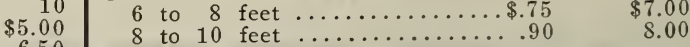
TEA'S WEEPING MULBERRY.

The most beautiful weeping tree of recent introduction. The slender branches grow downward parallel with the stem, forming an umbrella-like shape and a dense canopy which can be used as a playhouse for the children. The foliagc of this attractive tree is both graceful and beautiful. The most popular arrangement for planting is to place one on each side of the walk leading to the house. You cannot afford to leave this beautiful tree off your order. Prices: Each 10 $1 \mathrm{yr}$. head, $5-6 \mathrm{ft}$. stems $\$ 1.00 \$ 9.00$ $4 \mathrm{yr}$. head, $6-7 \mathrm{ft}$. stems $1.50 \quad 12.00$

\section{AMERICAN LINDEN.}

We make a specialty of this marvelous trec, as it is one of the hand. somest native trees we have. Its large leaves and beautiful blossoms, together with its dense, spreading habit of growth, make it valuable as a lawn tree as well as for wind-breaks, shelter belts, shade for stock, etc. Thousands of farmers, landowners and stockmen in general are planting this variety around their barns and in their variety around the

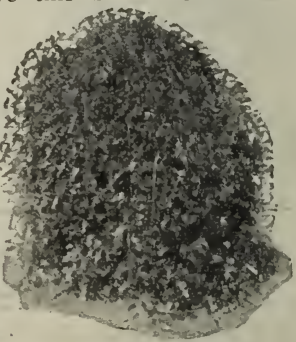

Weeping Irulberry.

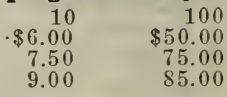

$\begin{array}{rrr}\text { Each } & 10 & 100 \\ \$ .65 & \$ 6.00 & \$ 50.00 \\ .90 & 7.50 & 75.00 \\ 1.00 & 9.00 & 85.00\end{array}$

1 to $11 / 2$ inches diameter

Note: Write for prices on larger sizes, up to 9 inches in diameter. 


\section{Trees--"Ideal Collection"--Price $\$ 2.00$}

This is our home beautificr collection. Sucli splendid value as this collection offers is really rare to find. If you follow directions in planting and care, the trees in this collection will soon develop and provide all the shade and protection your place will need. These varicties will all grow vigorously and quickly into handsome, noble trees. A valuable collection for suburlanitcs as well as for farm homc planting. The low price at which this "Ideal Collcction" is offered will place " $\boldsymbol{\text { Iill's }}$ Iardy Dundee Grown " trees in thousands of lomes througliout the country.

3 Horse Chestnut, 3 feet 3 Norway Maple, 3 feet These 21 Beautiful Shade Trees3 American Elm, 3 feet 3 . Hard Maple, 3 feet packed and $\quad$ only \$2.00 3 White Oak, $\quad 2$ feet 3 Black Waliut 3 feet j carshere for

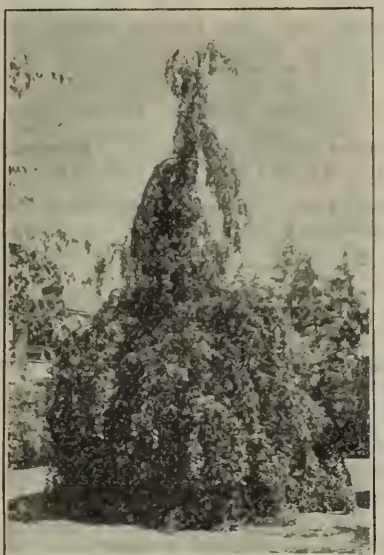

Young's Weeping Birch.

\section{WALNUTS.}

BIACK WAINUT. This majestic tree grows to great size, lias rough, dark bark, and bcautiful foliage. One of the noblest trees of the American forcst. Its timber has been at a higli premium for years, and its delicious oily nuts bring up visions of brown-stained hands of boyhood.

\begin{tabular}{|c|c|c|c|c|c|c|}
\hline \multicolumn{3}{|c|}{ Prices: } & & Each & 10 & 100 \\
\hline $11 / 2 \mathrm{t}$ & to 2 & feet & $\ldots \$$ & .05 & .40 & 3.00 \\
\hline 2 & to & fect & $\ldots \ldots \ldots \ldots \ldots \ldots$ & .08 & .65 & 5.00 \\
\hline 3 & to & feet & & .10 & .75 & 7.00 \\
\hline 4 & to 6 & feet & 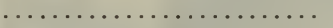 & .15 & 1.25 & 10.00 \\
\hline 6 & to 8 & feet & $\ldots \ldots \ldots \ldots \ldots \ldots \ldots \ldots$ & .25 & 2.00 & 15.00 \\
\hline t & to 10 & feet & 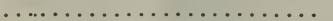 & .35 & 3.00 & 25.00 \\
\hline
\end{tabular}

\section{BIRCH.}

WFITE RIRCE. This tree is a rapid grower with beautiful spray-like branclies. The white, paper-like bark of this tree is especialiy striking when planted among evcroreens. It grouvs to be a large tree, 60 feet high. Prices: 2 tot 3 feet, 5 cents each; per 10,10 cents; per $100, \$ 3.00$. 3 to 4 feet, 15 cents each; per 10, $\$ 1.00$; per $100, \$ 10.00$.

CUT-IEAVED WERPING BIRCE. This is the favorite of all trees for lawn and cemetery planting. Its gracefully drooping branches and delicate lcaves, together with the silvery white bark so characteristic of the birches, all combine to make it the most popular tree grown. It should be on every lawn. Prices: 6 feet, $\$ 1.00$ each; per $10, \$ 8.50 .8$ feet, select, $\$ 1.50$ each; per $10, \$ 12.50$.

YOUNG'S WEEFING RIRCF. 'This is a new production and is a worthy member of the Birch family. Its habits are dwarfish and its leaves as well as its branches bend toward the ground. That this tree may become better known we are offering it low this season. Prices: 2 to 3 feet, 50 cents each: per $10, \$ 4.50$. 3 to 4 feet, 75 cents each; per $10, \$ 6.00$.

\section{ELM.}

AMERICAN WHITE FIM. This is the native American White Elm and is doubtless so well known that a lengthy description is needless. This tree is adapted for every purpose. It is used for street, park, boulevard and lawn planting, and also for forestry and commercial purposes. Illustration shows a block of our Elms as grown for ornamental purposes.

\begin{tabular}{|c|c|c|c|c|}
\hline Price & & Each & 10 & \\
\hline to & 3 feet & $\ldots \ldots \$ .1$ & $\$$ & 4.00 \\
\hline & 4 fee & $\ldots \ldots \ldots \quad .1$ & 1.00 & 6.00 \\
\hline 5 & & .28 & & 12.0 \\
\hline to 10 & 0 feet & .75 & 6.5 & 50. \\
\hline $\begin{array}{ll}0 & 3 \\
\end{array}$ & 3 inch & $\cdots \cdots=250$ & 20.00 & 180.00 \\
\hline & 4 inch & diameter .. & 30.00 & \\
\hline
\end{tabular}

\section{ASH.}

EUROPEAN MHOTNTEIN ASE. A very pretty small sized trce with abundant clusters of large orange berries in autumn. It is already well known and highly esteemed as one of the most beautiful trees that grow. $A$ vigorous grower and will add much to the beauty of your home. Very hardy and grow's well in all States. Prices: 5 to 6 feet, 30 cents each; per $10, \$ 2.50$. 6 to 8 feet, 50 cents each; per $10, \$ 4.50$.

OAK-IEAYED MOUNTAIN ASH. An extremely pretty little tree and at once a favorite wherever seen. It is of pyramidal habit of growth, and has deeply lobed oaklike leaves, green above and wooly underneath. The demand for this beautiful tree has more than doubled during the last few years. It is entirelv hardy and when orce planted will take care of itself. Prices: 4 to 5 feet, 50 cents each; per $10, \$ 4.50$. 5 to 6 feet, 75 cents each; per $10, \$ 7.00$.

Special Offer

No. 112

One each of Black Walnut, Norway Maple, Linden, American White Elm, European Mountain Ash, all 5 feet high, for $\$ 1.00$. These are all first-class shade trees of Hill's Highest Quality.
WE CAN FURNISE most of the varicties listed on this page in Seedling sizes in large quantities for Forestry or Woodlot planting. See pages 21 and 22.

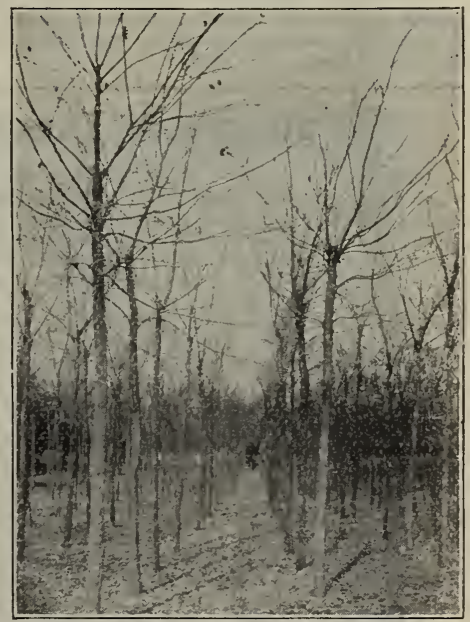
Nurseries.
Block of American Elms in Dundee 


\section{OAKS.}

The Oaks are known from the Atlantic to the Pacific, and as a practical tree for all purposes they are unsurpassed. Our soil and climate here is especially adapted to the culture of Oaks-in fact the native timber in the beautiful Fox River Valley in which our Nurseries are situated, consisted, at an early date, almost entirely of Oak. We plant annually many hundreds of bushels of f.corns to supply the immense demand. For price on Seedlings see page 22.

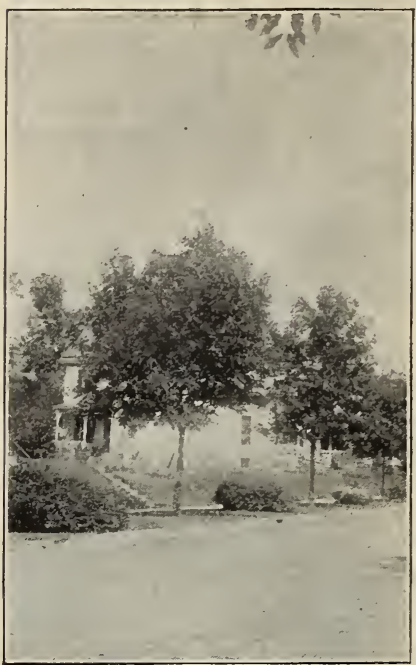

American Red Oak.

Note: On your tree bank do not plant trees closer than 20 to 30 feet apart.

\section{Special Offer No. 113 \\ 1 Red Oak, 5 to 6 feet 1 Pin Oak, 5 to 6 feet 2 White Oak, 2 feet Packed to go by Express}

AMFRICAN RID OAK. The king of Oaks for commercial as well as ornamental purposes. It is a distinct native American variety. A rapid grower with large foliage which turns a purplish scarlet hue in the Fall. For ornamental purposes it is unsurpassed. From the illustration you can see what a beautiful street tree it makes, and so strong, sturdy and upright looking. From a commercial standpoint the Red Oak is extremely valuable, as the virgin oak timber stands are rapidly passing away, and the timber commands almost any price. An acre alone planted to this variety would, in the years to come, prove a valuable investment for your children. But even if you do not want to plant so many, you should plant a few on your grounds around your house or barns-they grow into such magnificent, noble specimens, and live to be centuries and centuries old. Prices: 5 to 6 feet, 50 cents each; per $10, \$ 4.00$; per $100, \$ 35.00$.

PIN OAK. An ideal street tree. It is distinguished by its elegant growth and the drooping tendency of its limbs, and fine, deeply-cut foliage, which, in the Fall, colors brilliantly. This variety planted on your tree bank will add an air of distinction to your home and grounds that nothing else will give. Prices: 5 to 6 feet, 75 cents each; per 10, $\$ 7.00$; per $100, \$ 65.00$.

Please tell me what varieties I ought to plant on my lawn, how far apart for a bedge, etc., what is the best variety for my tree bank, the varieties best suited for a windbreak, or information with regard to Catalpa, or the housewife wishes information about roses, shrubbery, etc. IVe get thousands of such letters every year asking for information on every conceivable subject pertaining to horticulture.

we want to help,you all we can and our "over half a century's experience" and expert knowledge prepares us to answer all questions conscientiously and in a thoroughly practical manner. Ask us often. It is a pleasure for us to help you and this service is given without charge.

WHITE OAK. The White Oak is a broad spreading massive tree and is next to the Red Oak in point of practical value. It has same general characteristics of the Oak family. It is entirely hardy-no trouble to grow and does well anywhere. Prices: $1 \mathrm{~T} / 2$ to 2 feet, 10 cents each; per 10,60 cents; per $100, \$ 5.00$.
Dear Sir: The trees arrived May oth in good shape and accept thanks for your generous count. $I$ shall recommend you to my friends.-W. $K$. Krauter, Bucyrus, Ohio.
Dear Sir: I want to say that I am well pleased with the trees you shipped me. I think they are fine. I will want more next year. $-S$. J. Warren, Hopkins, Mo.

\section{EUROPEAN LARCH.}

This is the most valuable timber tree we have. A very rapid grower. A small area planted to European Larch, will, in a few years, furnish you all the firewood you can use. This is the tree for the farmer. Plant a grove, and in five years you can begin to cut out and thin. You will have wood to sell to your neighbors. See Illustration, page 22. This tree is much used for planting along fence lines, because it quickly grows up into a living fence post and lasts a lifetime, and forming at the same time a valuable wind-break which will increase the value of your land, hold the moisture in your soil, and increase your crops. In planting a grove, to get the best results the trees should be planted from 4 to 8 . feet apart each way. An acre of European Larch in from 5 to 8 years will pay for itself many times over, and then you have only thinned out the trees here and there. For price in Seedlings see page 22 .

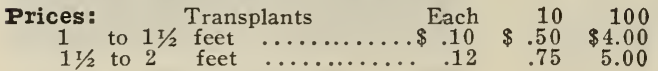

Number of Trees Required Per Acre.

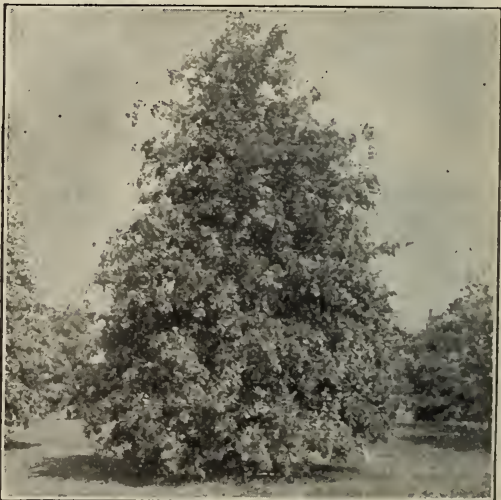

Pin Oak.
At 4 feet apart each way, $\ldots \ldots \ldots .2,729$

At 5 feet apart each way, ........1,742
At 6 feet apart each way, $\ldots \ldots \ldots \ldots 1,200$

At 8 feet apart each way, ........... 680 


\section{CHESTNUTS.}

HORSE CHESTNUT. In May it is covered with magnificent erect spikes or pyramids of white flowers. As a single lawn tree it has no equal. The foliage is large and dense, and it bears large brown nuts. Our trees are stocky and strong and will soon develop into beautiful large specimens.

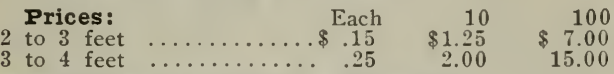

AMERICAN SWEET CHESTNUT. This fine native tree is a rapid grower and its nuts are sweeter than any variety grown. It should be closely pruned when planted.

Prices:

5 to 6 feet Each
100 $\$ 35.00$

\section{CATALPAS.}

We offer two varieties of the Catalpa family-the Hardy Catalpa Speciosa and the Catalpa Bungei. The Catalpa Speciosa is mostly valuable because of its popularity along commercial lines, although when planted on lawns it makes a very ornamental tree. The Catalpa Bungei is useful for ornamental purposes only.

CATAIPA SPECIOSA. This valuable tree is a rapid grower. The foliage is of a light green color with flowers two inches or more broad. It flowers in June. Its seed pods are from ten to eighteen inches long. It is getting more popular each season as a lawn tree because it has such pretty leaves and flowers.

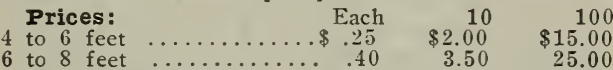

6 to 8 feet

CATAIPA BUNGEI. The illustration gives a better idea of what this wonderful tree is than any description we could give. The tops are grafted on straight stems, forming a pretty dome-shaped head of great, soft, heavy leaves. To get best effect, plant along both sides of a driveway. The demand for these trees has been growing by leaps and bounds, and they are now planted all over the country, except in some of the extremely cold parts. It does not grow scraggy but keeps its round-headed, straight-bodied appearance always. Single specimens planted on lawns attract great attention. If you really want something out of the ordinary, and different from anything your neighbor has, you ought to have the Catalpa Bungei.

\section{Prices:} Each
$\$ 1.25$

6 feet stems

$\$ 11.00$

Write for prices on larger quantities.

Read what Mr. Younghans, of Gothenburg, Nebr., says about our Trees.

We get thousands of such letters every year, and most of them are even more enthusiastic in their praise of our stock, our methods of doing business, and our special service. Our interest does not stop after we have placed trees on board cars for shipment. We want to know what success you have when they are planted out. Every customer satisfied, or your money back, has been our motto for over half a century. It is because of the reputation we have gained for fair and square dealings that has built up this immense business, and made " Hill's Hardy Trees" known all over the world.

\section{POPLAR.}

CAROIINA POPLAR. A good tree for allaround use. It is unequaled for screen purposes and equally valuable for street tree. Rapid grower, and desirable when quick shade is wanted. It seemingly thrives just as well on poor soil as it does in rich, and grows into a fine shaped spreading tree. The demand for this tree during the last few years has been enormous, and it well merits its popularity. This tree is much used for planting to hide unsightly objects.
Prices:
6 to 8 feet Each 10
8 to 10 feet

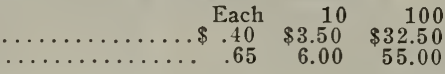

Planting directions for shade trees-see page 20.

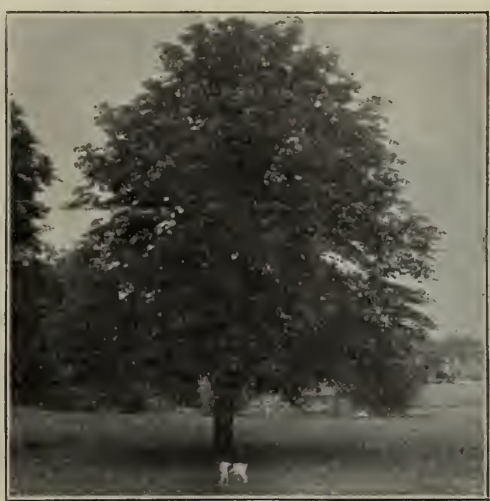

Horse Chestnut.

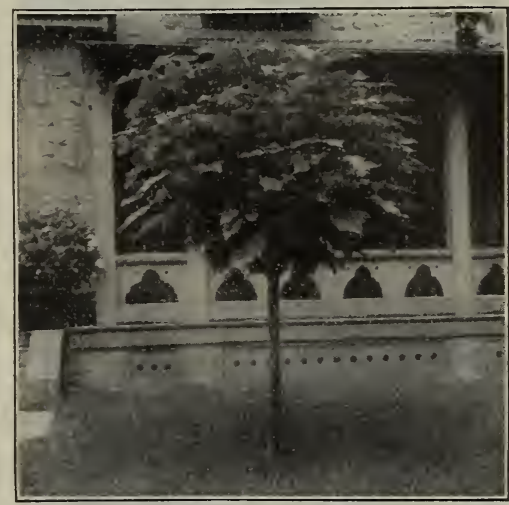

Catalpa Bungei.

Dear Sir: I received the trees last week, and an well pleased with them. They were in fine condition when they arrived. Yours iruly.-Wm. Young. hans, Gothenburg, Nebr.

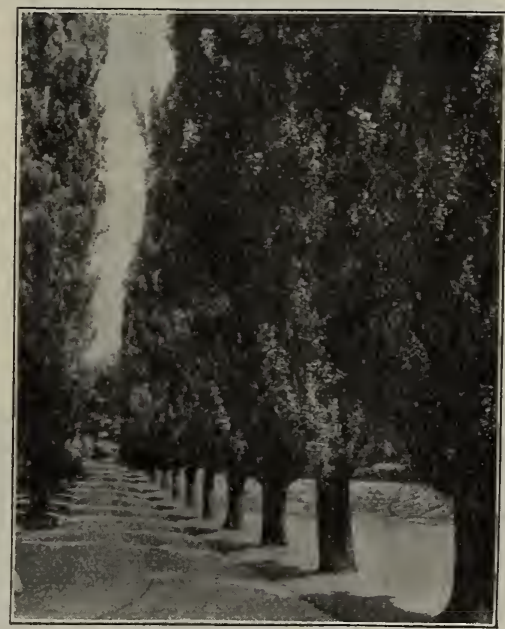

Poplars Along Drive. 


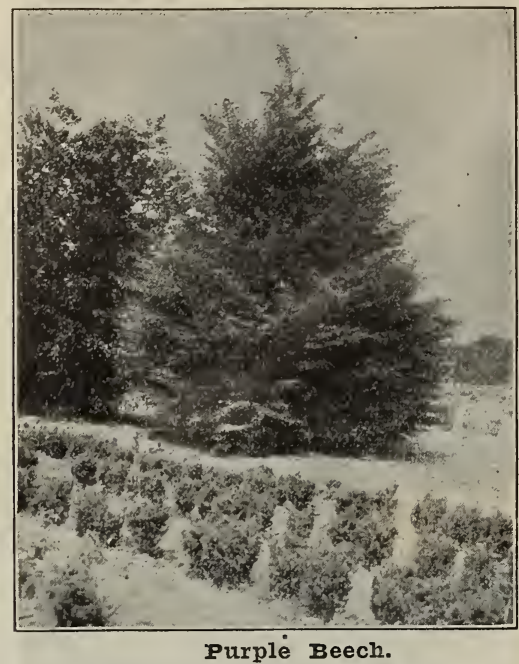

SPECIAI OFFER No. 114.

1 River's Purple Leaf Beech 4 feet

1 Flowering Cheiry 2 feet

Packed and delivered on cars for express shipment.

Price $\$ 1.00$.

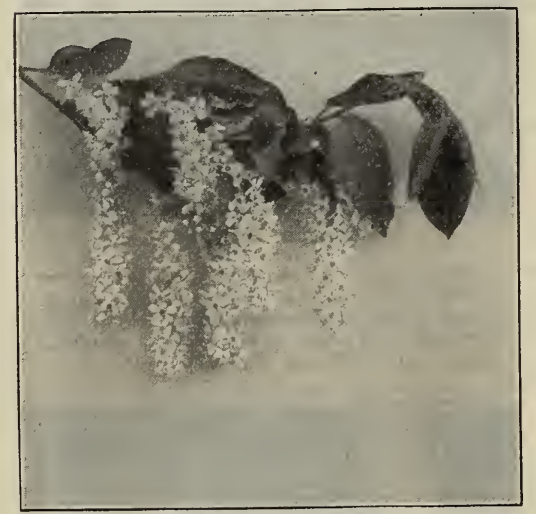

Flowering Cherry.

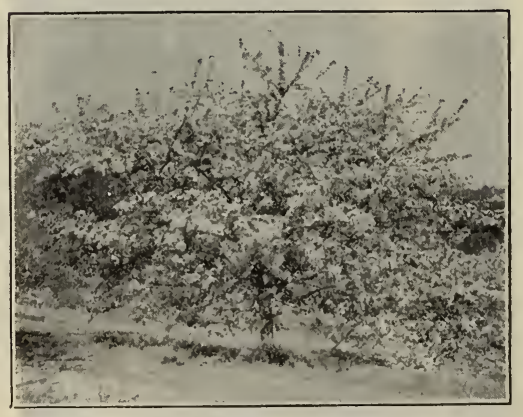

Flowering Crab.

\section{HILL'S EXTRA FANCY ORNAMENTALS.}

THE BEAUTIFUI GRAFTED RIVER'S PURPLE IEAF BEFCH. Sometimes called Riv. er's Blood Leaf Beech. A wonderfully beautiful tree and comparatively new, and without doubt one of the most valuable additions to our ornamental department that has been added for many years. They grow into large noble specimens, and the leaves or foliage which has made the tree famous are a deep rich purple blood color. It is marvelously beautiful and every one wants it at sight. It grows into a dense, compact, perfectly formed tree. Prices: 4 to 5 feet, $\$ 1.25$ each; per ten, $\$ 11.00$.

EUROPEAN FIOWFRING CHERRY. An elegant new variety and a distinct ornamental tree. It grows rapidly, has glossy foliage, and long bunches of milk-white fragrant flowers in May, and succeeded by clusters of fruit which resemble Black Currants. Any one who enjoys beautiful trees will immediately fall in love with this one. You could plant nothing on your grounds which would attract more attention than this charming Flowering Cherry. Prices: 11/2 to 2 feet, 20 cents each; per ten, $\$ 1.80$. 2 to 3 feet, 25 cents each; per ten $\$ 2.00$.

BECHTEL'S SUPERB DOUBLE FLOWERED CRAB. This charming little tree, in early Spring is one mass of bloom. Its large fragrant flowers, of a white pinkish color are a sight to behold. From a distance the flowers have the appearance of small roses. From illustration you can see how beautiful this tree is when in bloom. Prices: 3 to 4 feet, 75 cents each; per ten, $\$ 7.00$. 4 to 5 feet, $\$ 1.00$ each; per ten, $\$ 9.00$.

SPECIAT OTFER No. 115.

1 each of above three varieties, first size, \$1.95.

2 each of above three varieties, large size, $\$ 4.45$.

GENERAI DIRECTIONS FOR PLAINTING.

Dig holes, in the first place, large enough to adinit the roots of the tree to spread out in their natural position; then, as before directed, let one person hold it in an upright position, and the other shovel in the earth, carefully putting in the finest and the best from the surface among the roots, filling every interstice, and bringing every root in contact with the soil. WWhen the earth is nearly filled in, a pail of water may be thrown on to settle and wash in the earth around the roots; then fill in the remainder and tread gently with the foot. The use of water is seldom necessary, except in dry weather, early in Fall or late in Spring. Guard against planting too deep; the trees, after the ground settles, should stand in this respect as they did in the Nursery. In very dry, gravelly ground the holes should be dug twice the usual size and depth, and filled in with good loamy soil.

Dear Sir: The trees came all right, and am well pleased. Many thanks for the extras.-A. M. White, Coronna, Ind., April II, Igo8.

TRERS TREE. Send the names of 24 of your friends and neighbors (landowners) whom you tilink would purchase Kill's Hardy Trees, and we will send you, postpaid, 25 Norway Spruce seedlings, 6 to 8 inches high, for your trouble.

PURPIE IEAVED PIUM. (Prunus Pissardi). The finest purple-leaved small tree or shrub. The foliage is a dark, rich purple. Grows 25 feet tall. Prices: Strong 3 -feet trees, 35 cents eacli; per ten, $\$ 3.00$. 


\title{
A Word on the Subject of Forestry.
}

\author{
TREE PLANTING FOR PROFIT.
}

THE DUNDEE NURSERIES lave been closely allied with Forestry interests in the United States during the past quartcr of a century because we have furnished the United States Government with a large part of the trees which they have used in their planting projects, and we liave therefore made a close study of the subject in a thorouglily practical way, and feel that we can, with authority speak on especially the growing and rcproducing part, in their relation to the Farmer, who, perhaps wishes a woodlot, or the individual who wishes to invest his surplus savings in a Catalpa or Black Locust plantation, or, the large Railroad Corporation, or Manufacturing Company who wishes to plant out large tracts into trees that will be suitable for Railway ties, woodpulp, timber, etc.

\section{WHY THE FARMER SHOULD PLANT TREES FOR PROFIT.}

The importance of establishing woodlots or shelterbelts on farms that lack them is no less obvious than the necessity of raising staple crops. Thic provident farmer cannot afford to buy fire-wood, fence-posts, or building timber any more than he can afford to buy corn and wheat. A part, if not all, of the wood-material used on the farm can and should be grown there.

Tree planting for profit is just as much a matter of interest to the farmer who wishes to plant a wind-break or a grove as it is to the large paper mill concern or railroad which wishes to reforest hundreds of acres of land. Happy will be the farmer who decides to set aside a small portion of his land for tree-planting. He not only adds riches to his farm, but he confers a blessing upon every luman being that lives near any stream which flows througl his farm or lias its source on his ground. Solid is the foundation that the farmer builds who looks years aliead and provides for himself and children ample woodlands for timber and other wood supplies. Take, for instance, the one single item of fence-posts. Like many other farming States, Iowa has a lack of fence-post material and it is estimated that in that State alone the farmers spend $\$ 1.250,000$ for fence-posts annually.

A properly managed forest plantation will produce, when the trees have reached post size, 3,500 posts three to five inches in diameter per acre.

Progressive farmers all over the country are meeting this question fairly and squarely by setting aside an acre or two to plant for timber purposes.

\section{CATALPA GROWING FOR PROFIT.}

The Catalpa Speciosa tree is the fastest growing American tree known that has a high value as timber. Catalpa trees, if planted on good soil and well tended while small will grow nearly one inch in thickness each year of their growth. At ten years of age they will average to make two good fence posts to each tree; at fifteen they will make light telephone poles, and at twenty years, heavy 30 -foot telephone poles. On fairly good soil, from four to six feet, or from five feet by eight feet, or one thousand to two thousand trees to the acre, is about the proper distance apart to set them. When they are large enough to make two posts to the tree, thin out one half the trees.

A progressive Ohio farmer wlien asked why he had planted fifty acies to Catalpa said: "Why $\operatorname{did} I$ do it? Because I know it will pay me-pay me much more than ordinary farming.

\section{REFORESTING CUT OVER LANDS.}

There is a large amount of land in the East, which, though practically worthless for other purposes, has very favorable conditions for reproducing the Native White Pine. The expense of planting these lands is comparatively low, because two-year-old seedlings can be used. Following the lead of the State and National Governments, individuals and corporations are rapidly replanting woodlots and cut-over timber lands at the rate of hundreds of acres a year. We are now past the experimental stage, the planting expense can now be ascertained almost to the fraction of a cent per acre. The up-keep per year-the number of years before you can look for returns, and how big the returns will be, are facts which you can know before you plant a tree. IVe are pleased to say that we number among our customers the National Government, most of the State Forestry Departments, and practically all of the large private concerns, and furnish them trees in large quantities for the extension of their forest interests.

\section{OUR SERVICES FREE OF CHARGE.}

If you have any questions to ask concerning the above or wish any further information do not be backward about writing us. We want to help you in any way we can. Tell us how much land you wish to plant to trees, the nature of the soil, etc., and for what purpose you want to grow the trees (railway ties, fence posts, fire-wood, lumber, shelter belt, etc.), and we will give you a complete planting plan, telling what varieties to plant, how many plants to acre, season to plant, best method planting plan, telling what varieties to plant, how many delivered on cars here. Growing these trees in such immense quantitięs we are enabled to make extremely low prices. For complete price list in such immense quantitiess

Tres. - In connection with our Forestry Department is our Tree Seeds Department. Reing the in all the most important collecting districts in this country and Europe, we are able to furnish our customers with the highest quality Tree and Shrub Seeds at lowest prices. No seeds leave our ware custo unless they test up to the same high degree of germination which we demand for our own plantings. Write for prices on seeds.

Note: We will undertake to grow seedlings under contract for parties wishing a certain number each season. Write for further particulars.

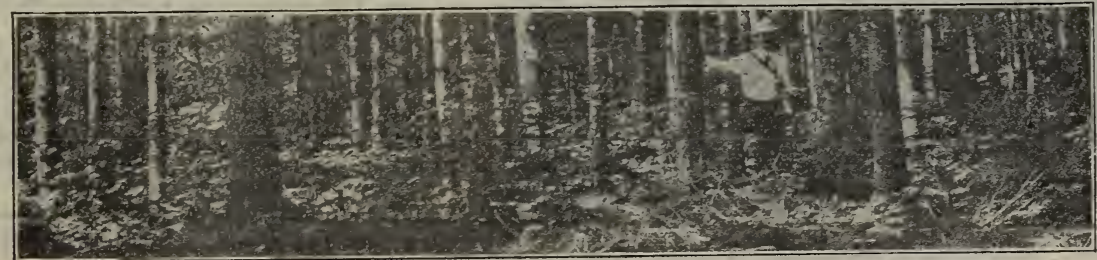




\section{Seedlings for Forestry Planting}

Plant hardy, fast growing trees for timber and forests, firewood, stock shelters, etc. The United States Department of Agriculture, Bureau of Forestry, will give you, free of charge, valuable information regarding the planting of young trees for all practical purposes. It means money in your pocket. Don't delay. Order the stock and plant it at once. The following varieties are all money makers and will surorise you with their rapid growth. We grow these strong healthy seedlings by the millions, and sell them all over the United States, Canada and Mexico. All seedlings are carefully dug and sorted to size and tied 50 and 100 per bunch. We use plenty of damp moss in packing. Write for further information on any of the seedlings we offer.

AMERICAN EIM. This is one of the hardiest trees for prairie planting, and a rapid grower. The wood is extremely valuable tor the manufacture of Agricultural implements, etc.

Prices: 1 year seedlings 12 to 18 inches per $100 \$ .75$, per $1,000 \$ 4.50$

MARD OR SUGAR MAPIE. Very hardy tree, the wood being heavy, compact and strong. Maple Sugar is almost the exclusive product of this tree.

Prices: 1 year seedlings 6 to 8 inches per $100 \$ 1.00$, per $1,000 \$ 7.00$, per $10,000 \$ 65.00$
10.00 ,
90.00

CATAIPA SPECIOSA. We have never been able to grow enough of this wonderful tree. Nearly every year the greater part of our stock in sold early in season. See pages 19 and 21.

Prices: 1 year seedlings 18 to 24 inches per $100 \$ .75$, per $1,000 \$ 6.00$, per $10,000 \$ 55.00$
1 “ “6 $\quad 6$ to 12
.50 ,
3.50 ,
25.00

EUROPEAN IARCH. Extremely fast grower. Wood is valuable for posts, telephone poles, fuel, etc. Does well in all parts of the country except in extreme western mountainous States. Very profitable for prairie planting. Grows to 75 feet in height. See illustration.

Prices: 2 year seedlings 12 to 18 inches per $100 \$ 2.00$, per $1,000 \$ 12.00$

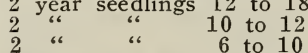
1.50
0.00
7.00

\section{DO YOU WANT TO INCREASE THE VALUE of your farm $\$ 1,000$ ? Then read this. Special Forestry Offer No. 116.}

This will be more valuable in a few years' time, and more safe and sure than a life insurance policy. We are making it because we want every farmer, stockman, and landowner in the United States to become acquainted with " Fill's Fardy Trees." These trees will increase the value of your farm $\$ 1,000$ in a very few years. Plant five feet apart each way.

1,000 American Elm, seedlings, 10 to 12 inches

1,000 Catalpa Speciosa, seedlings, 6 to 12 inches

1,000 European Larch, seedlings, 8 to 10 inches

\section{Price, $\$ 10.00$ \\ Freight Prepaid.}

SWFET CHESTNUT, Chestnut is adapted to Eastern soil, where it grows naturally. Its timber is valuable, and there are large profits in growing them for the production of nuts for market. Prices: 1 year seedlings. 8 to 12 inches, per $100 \$ 2.00$; per $1,000 \$ 15.00$. 6 to 8 inches, per 100 $\$ 1.50$; per $1,000 \$ 12.00$. 4 to 6 inches, per $100 \$ 1.00$; per $1,000 \$ 9.00$.

RED OAK. This is the variety to plant for railroad ties. We furnish annually several hundred thousand Red Oak seedlings to Railroad Companies to be grown for Railroad ties. It is the most valuable variety of the Oak family for that purpose. Prices: 1 year seedlings, 8 to 15 inches, per $100 \$ 1.50 ;$ per $1,000 \$ 10.00$. 1 year seedlings, 6 to 8 inches, per $100 \$ 1.00 ;$ per $1,000 \$ 7.00$.

BIACK IOCUST. This tree is a fast grower and excellent for fuel. Prices: 1 year seedlings, 2 to 3 feet, per $100 \$ 1.25 ;$ per $1,000 \$ 8.00 ;$ per $10,000 \$ 70.00$. 18 to 24 inches, per 100 , 75 cents: per $1,000 \$ 5.00$; per $10,000 \$ 45.00$. 12 to 18 inches, per 10075 cents; per 1,000 ; $\$ 3.50$; per

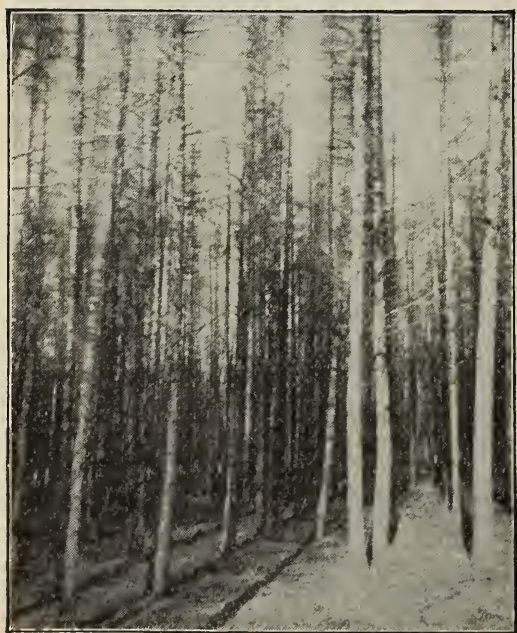

European Iarch Grove in Illinois.

\section{$1,000 \$ 2.50$; per $10,000 \$ 20.00$.}

AMERICAN BEECH. One of the most valuable of all our native American trees. Grows to large size and the wood is used for numerous purposes.

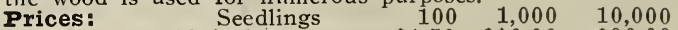
2 year, 12 to 18 inches .......\$1.50 $\$ 10.00 \quad \$ 90.00$

BIACK WAINUT. Grows rapidly and is one of the most valuable woods found in America, being used largely for interior finishing, etc. This timber is now very scarce. The nuts are much sought for and find ready sale.

Prices: $100 \quad 1,000$ 2 year, 18 to 24 inches ..........\$1.75 $\$ 12.00$ 2 year, 12 to 18 inches $\ldots \ldots \ldots \ldots \ldots \ldots 1.50 \quad \$ \ldots .00$ CFISTNUT OAK. Prices: 1 year seedlings, 4 to 6 inches, per $100, \$ 1.25$; per $1,000, \$ 10.00$.

AMFRTCAN IINDEN OR BASSWOOD. Wood mus con lumber and is much used for paper pulp. makes good lumber and is mitch used for paper pulp.
Seedlings 1 year, 15 to 20 inches ...........\$2.50 $\$ 20.00$ 1 year, 8 to 12 inches ............... $2.00 \quad 15.00$ NORWAY MAPLE. Prices: 1 year seedlings, 12 to 15 inches, per $100 \$ 1.75$; per $1,000 \$ 12.00$; per $10,000 \$ 100,00,1$ year seedlings, 6 to 12 inches, per $100 \$ 1.25$; per $1,000 \$ 10.00$; per $10,000 \$ 90.00$

HONEY IOCUST. Prices: 1 year seedlings, 4 to 6 inches, per $100 \$ .50$; per $1,000 \$ 2.50$. 1 year seedlings, 6 to 10 inches, per $100 \$ .75$; per $1,000 \$ 3.50$. WHITE BIRCH. Prices: 1 year seedlings, 10 to 15 inches, per $100 \$ 1.00$; per $1,000 \$ 8.00$; per 10,000 $\$ 70.00$. 


\section{Ornamental and Flowering Shrubs.}

Nothing adds more to the beauty of a place than to have the sides and background well filled with groups of shrubbery. Whether you have a lawn of many acres or a humble door-yard we commend this class of plants as indispensable to the real beauty of your home. If you select with care you can have a succession of blooms from April to snow, to say nothing of the beautiful color, form and shadow effects of flowers, foliage and bright berries. It is our aim to produce everything in flowering shrubbery that is useful, hardy and worthy of cultivation in all climates. To no department do we give more attention than to our shrubbery department. Only by growing them in such immcnse quantities are we enabled to sell our "High Grade Dundee Grown" shrubs at such low prices. In planting shrubbery prepare the ground and maintain it as if for a crop of potatoes. Plant in the Fall or Spring about 4 feet apart and mulch with straw or leaves. The time of bloom and height at maturity will be found under each varicty.

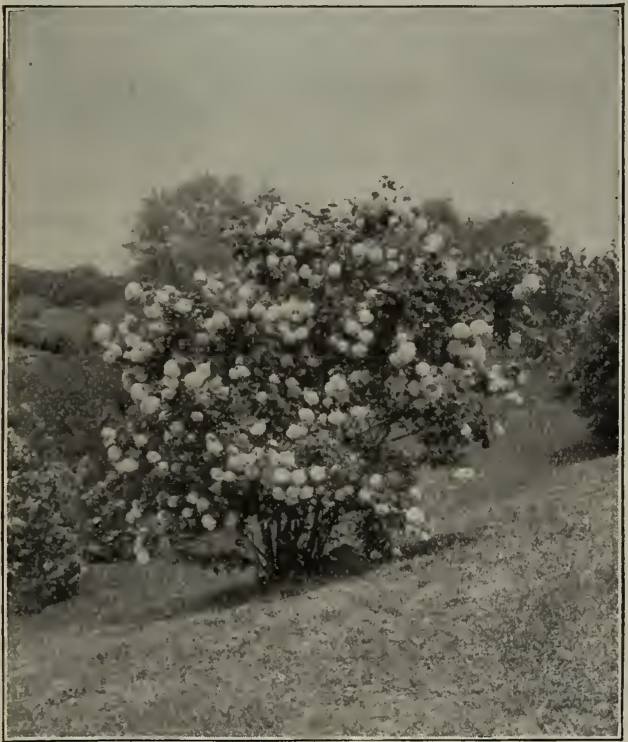

Beautiful White Double Flowering Snowball. What a Gorgeous Display of Blossoms.
BEAUTIFUI WHITE DOUBIE FIOWERING SNOWBAII (Viburnum Opulus Sterlis). One of the most charming hardy flowering shrubs in existence. Bears great clusters of pure white globulous flowers, like real balls of snow. Covered with bloom for weeks in the Spring. Grows five to seven feet tall-entirely hardy, needs no protection, splendid for door-yard, lawn and cemetery planting. Has rich dark green foliage crinkled and not subject to insects or diseases; does well anywhere and is always sure to bloom. Blooms in May. Prices: Good strong 2 year plants, 20 cents each; 3 for 50 cents; per $10 \$ 1.30$; per $100, \$ 12.00$.

HIGHBUSH CRANBFRRY (viburnum Opulus). A large growing shrub with beautiful white flowers which hang in clusters in late Spring and early Summer, followed by bright scarlet berries persisting all winter. A very showy shrub and should be on every lawn. Prices: Strong 2 year plants, 20 cents each; 3 for 45 cents; 10 for $\$ 1.30$; $\$ 12.00$ per 100 .

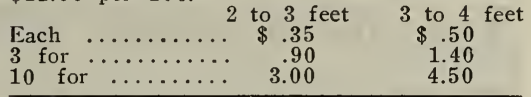

SPECIAI OFFER NO. 117.

Four Plants each of above varieties, strong 2 year old plants.

$$
\text { Price \$1.20. }
$$

WAYFARING TREE (Viburnum Iantana). A valuable species with beautiful white flowers, followed by berries that become pink, red and black in turn as they ripen. Prices: Strong 2 year plants, 20 cents each; 3 for 45 cents.

ARROW WOOD (Viburnum Dentatum). 6 to 8 feet. May, June. A bushy shrub with upright branches especially admired for the abundance of its scarlet fruits that cling to the branches a long time. It has beautiful creamy white flowers. Prices: 2 year Plants, 20 cents each; 3 for 50 cents; $\$ 1.40$ per 10 .

SPECIAI $\left\{\begin{array}{l}2 \\ 2 \\ \text { Spirea Van Houtti, Spirea }\end{array}\right.$

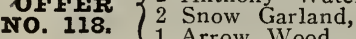

Price $\$ 1.05$ Prices: plant. Each 10 100

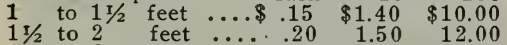
$2^{1 / 2}$ to 3 feet $\ldots . .25 \quad 25 \quad 2.00 \quad 15.00$ 3 to 4 feet $\cdots . .40$... $3.50 \cdot 30.00$ PERPETUAI BTOOMING RED SPIREA (Anthony waterer). A fine hardy pcrpetual blooming shrub particularly desirable for the door-yard and lawn, makes nice shapely bushes 2 to 3 feet high; begins to bear its large flat clusters of rich rosy red flowers almost as soon as planted, and continues blooming at short intervals all through the Summer and Fall. Prices: Strong 2 year plants, 20 cents each; 3 for 45 cents: 140 per 10 . cents each; 3 for JAPANESE SNOW GARIAND SPIREA (Spirea Thumbergii). 3 to 4 feet. June. A beautiful shrub with numerous slender branches, forming a dense feathery bush, 3 to 4 feet tall. Native of China and Japan. Extremely brilliant foliage, bright green, fading in Autumn with brilliant tones of orange and scarlet. The beautiful pure white flowers, which appear in great orofusion in early Spring, cover the plant $a_{2}$ with a mantle of snow. Prices: Strong 2 year plants, 25 cents each; 3 for 65 cents; $\$ 1.50$ per $10 ; \$ 14.00$ per 100 .

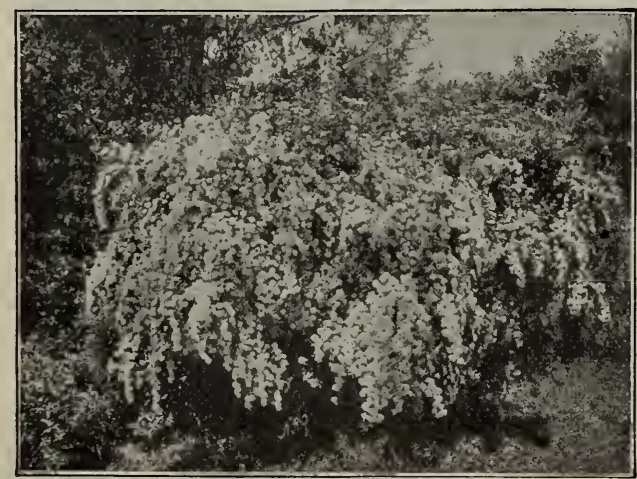

Spirea Van Houti.

OUR CHOICE IAWN COIIECTION, SPECIAT OFFER NO. 119

One each of above seven varieties in extra selected 2 year plants for \$1.25. 


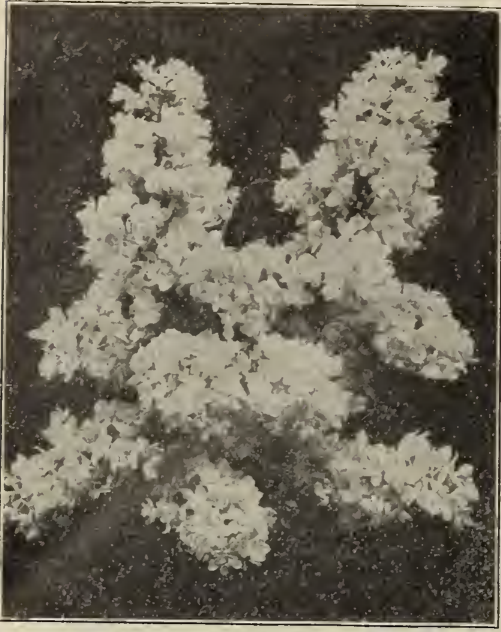

The Deliciously Fragrant Iilac.

\section{Lilacs (Syringa).}

Nearly every one is fond of Lilac blossoms. Their sweet fragrance comes with the first breath of Spring and their delicate colors of blue and white seem like a legacy from our grandmother's garden. They bloom in May and grow eight to ten feet in height.

OID IASHIONED PURPIE IIIAC (Syringa Vulgaris). Strong, vigorous, upright growth with rich dark green foliage and large panicles of fragrant purple flowers.

STANDARD WHITE IIIAC (Syringa Vulgaris Alba). Same habit of growtl as the Purple Lilac, but with pure white fragrant flowers.

Frices: Purple and White, 15 cents each; 3 for 40 cents; $\$ 1.25$ per $10 ; \$ 12.00$ per 100 .

BEAUTIFUI NEW GRAFTED IIIACS. DUring the last few years many ncw varieties of Lilacs have been produced. We offer only those which have proven to be exceptionally valuable. The following are a distinct improvement on the old sorts and a trial will make you more enthusiastic over them even than we are As they can be produceed only by the long and careful process of grafting they are a trifle more expensive than the common sorts, but they more than makc up for it in their wonderful bloom.

SYRINGA-CKAS. X. A wonderful plant. Color, dark lilac red.

SYRINGA-MARIE IEGRAY. Its blossoms are creamy white.

SYRINGA-IMME. C. PERIER. A beautiful double white variety, vcry large.

SYRINGA-SOUV. DE SPATH. Large light purple blossoms.

SYRINGA-PRES. GREVEY. Beautiful pale blue Lilac.

Prices: For all above Grafted Lilacs, selected bushes, 3 feet high, extra strong, 75 cents each; $\$ 2.10$ for 3

HOITY-TEAVED MAFONTA (Mahonia Aquifolium). A valuable Evergreen shrub which retains its green appearance all winter. It grows to medium size with purplish shining prickly leaves and showy bright yellow flowers in May succeeded by bluish berries. Prices: Strong 2 year plants, 25 cents each; 3 for 60 cents; $\$ 1.50$ per 10 .
JAPANESE MAFONIA (Mahonia Japonica). A new Evergreen slirub recently introduced from Japan. It lias large distinct leaves and in the month of May it is covered with delicate yellow flowers which gives it a striking appearance. Frices: Strong 2 year plants, 25 cents each; 3 for 60 cents.

\section{Weigelias.}

The Weigelias occupy an eminent place in the shrub family. They produce in June large superb trumpet-shaped flowers of all shades and colors from pure white to red. They make a broad vigorous growth. Five to eight feet in height. They flower after the Lilacs in June.

THE BEA UTIFUI POSE COIORED WEIGgIIA (Weigelia Rosea). An elegant shrub with fine rose colored flowers. This was introduced from China some years ago and sprang into instant favor. Include this in your order.

WEIGEIIA EVA RATHIF. A splendid new variety and perhaps the handsomest yet pro. duced. Purplish red flowers with creamy whitc markings.

Prices: On Weigelias, 2-year, strong healthy plants, 25 cents each; 60 cents per $3 ; \$ 1.50$ per $10 ; \$ 13.50$ per 100 .

WHITE FRINGE (Chionanthus Virginica). 8 to 10 feet. An extremely odd and beautiful shrub. In June the graceful lace-like white flowers hang in drooping panicles between the rich dark leaves.

Prices: Strong 2-year plants, 20 cents each; 3 for 60 cents; $\$ 1.50$ per 10 .

PURPIE FRINGE (Rhus Cottinus). 8 to 9 feet. An old-time shrub or small tree of irregular habit. In Summer it is enveloped with a mass of fleecy purple bloom resembling smoke or mist.

Prices: Strong 2-year plants, 25 cents each; 3 for 60 cents; $\$ 1.50$ per $j 0$.

WITCF HAZEI BUSF (Hamamelis Virginiana). 8 to 9 feet. Grows very large and is much admired for its beautiful foliage and its massive, wonderful blooms.

Prices: Nice 2-year plants, 25 cents each; 3 for 60 cents; $\$ 1.50$ per 10 .

HILL'S HARDY SHRLE COLLECTION No. 120.

2 Spirea Van Houtti, ........2 year Ten best

2 Purple Lilac, ............. 2 year hardy shrubs.

2 White Lilac, ............ year $\begin{aligned} & \text { tion wlll be } \\ & \text { sent by ex- }\end{aligned}$

1 Grafted Lilac (our selection), .3 feet press at buy-

2 Rosea Weigelia, ........... year $\begin{aligned} & \text { er's ex } \\ & \text { Price }\end{aligned}$

1 Highbush Cranberry, ........2 year $\$ \$ 2.10$

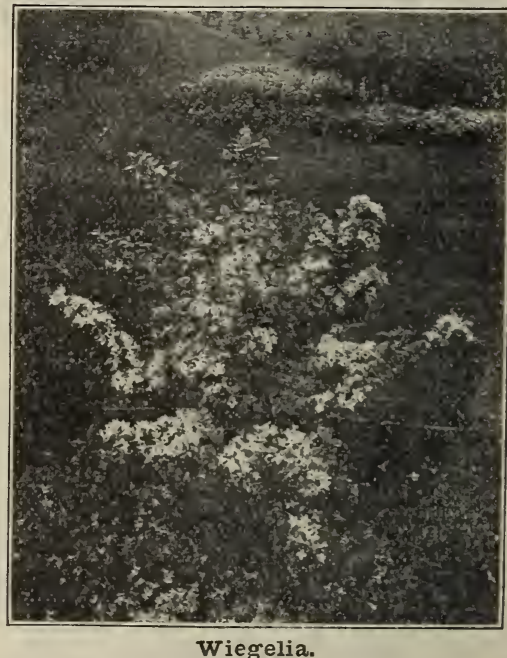

HOME FLORICUITURE. By Eben E. Rexford. A practical guide to the treatment of Flowering and other Ornamental shrubs. Illustrated, 300 pages, $5 \times 7$ inches. Cloth $\$ 1.00$. 


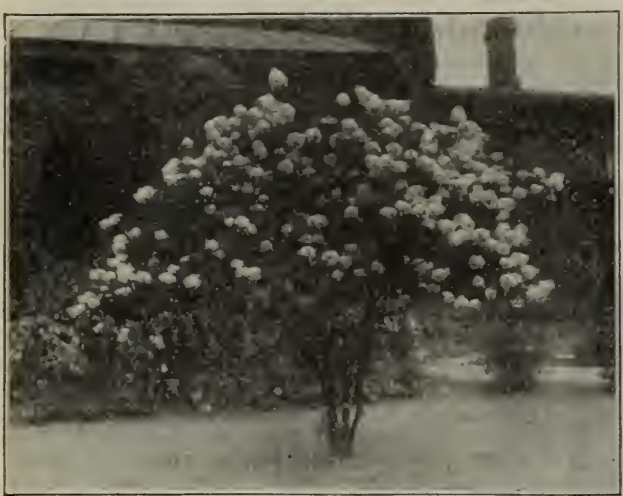

The Blooms of the Fydrangea Often Measure a Boot Iong.

PHILADFIPHUS OR SYRINGA (MOCK Orange). Ile offer six varieties of the Mock Orange family, knowing that each one is valuable and worthy of extensive planting, in fact, the Mock Orange has become indispensable in all lawn planting

GARIAND MOCK ORANGE (Philadelphus Coronarius). Has pure white, highly scented flowers. Grows large. One of the first to flower. Prices: 2-year plants 20 cents each; 3 for $t 0$ cents; $\$ 1.35$ per $10 ; \$ 12.50$ per 100

GOIDEN MOCK ORÁNGE (Philadelphus Foliis Aurea). A very pretty plant of medium size with yellow golden foliage-dwarfish habit. Prices: 2-year plants 30 cents each; 3 for 75 cents; $\$ 2.00$ per 10 . Extra select clumps 40 cents each: 3 for $\$ 1.00$

HYBRID IROCK ORANGE (Philadelphus Iemoinei Pleno). A variety with partially double very fragrant flowers. Prices: 2-year plants 25 cents each; 3 for 65 cents; $\$ 2.00$ per 10 . IFMOINE'S ERECT MOCK ORANGE (Ph. Iemoinei Erectus). A charming variety of upright growth, flowers small, yellowish white. Prices: 2-year plants 25 cents each; 3 for 65 cents; $\$ 2.00$ per 10 .

GORDON'S MOCK ORANGE (Ph. Gordonarius). A vigorous grower; blooms late, very valuable. Prices: 2 -year plants 25 cents very valuable. 5 Prices: 2 -year plan

PA VIIIION B I A N C I I O C K ORANGE (Ph. Pav. Blanc). An extremely valuable variety; a profuse bloomer. Prices: 2-year plants 50 cents each; 3 for $\$ 1.00$

CUT-TFAF SUMACH (Rhus Glabra Iaciziata). A very striking plant of moderate size, with deeply cut leaves, resembling fern leaves. Turns rich red in Autumn. Very scarce and rare. 7 feet. June. Prices: 2-year plants 25 cents each: 3 for 60 cents; $\$ 1.50$ per 10 . 3-year plants 30 cents each; 3 for 75 cents; $\$ 2.00$ per 10 .

EUROFIAN BIADDER NUT (Staphylla Pinnata). A handsome shrub with large clusters of cream colored foliage. Frices: 2-year plants 20 cents each; 3 for 45 cents; $\$ 1.20$ per 10 .

\section{SPECIAI OFFER NO. 121.} Hill's Garden Collection.

Extra large shrubs-to go by freiglit.

Hill's best eight shrubs, large size.

1 Highbush Cranberry

1 Spirea Yan Houtt

Hydrangea P. G.

...... 3 to $t$ feet

1 Golden Elder .............. $2_{2}^{21 / 2}$ feet

1 Flowering Cherry ........... to 3 to 3 feet Price, $\$ 2.45$.

Above shrubs in 2-year plants $\$ 1.50$
HYDRANGEA PANICUIATA GRANDIFIORA. This is undoubtedly the grandest and most beautiful of all the liardy fowcring shrubs, for the door-yard and lawn. Ihe illustration herewith gives some idea of its magnificeent beauty. We guarantee our IIydrangeas to give an abundance of bloom the first season. The flowers are rich creamy white, changing to pink, and borne in immense clusters. It blooms in August, the first and every succceding year, and continues to bloon for montlis. It is entirely hardy, no trouble to grow, and does well anywhere.

Frices: Strong plants that will bloom this season.

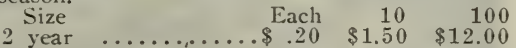

to 3 feet $\ldots \ldots \ldots \ldots .35 \quad 3.00 \quad 20.00$

Note: An annual shortening of branches tends to increase the size of the flowers.

THE BEAUTIFUI JAPAN OUINCE (Cydonia Japonica). An introduction from Japan. Their large brilliant flowers are among the first blossoms in Spring, and they appear in great profusion, covering every branch and branchlet. Superb for ornamental hedges. Prices: Strong 2 year plants, 20 cents each; 3 for 45 cents; $\$ 1.30$ per 10 .

DROOPING GOTDEN BEII (Forsythia Suspensa). A very pretty shrub of medium height; a native of China, and perfectly hardy iil this country. The plants are covered with beauti ful drooping bell-shaped yellow flowers, blooming very early in the Spring with the Lilacs. Prices: 2 year plants, 20 cents cach; 3 for 45 cents; $\$ 1.35$ per 10.

BYBRID GOIDEN BEII (Forsythia Intermedia). A wonderful new Hybrid production of the Golden Bell. If you want something out of the ordinary, order this. Prices: 2 year plants, 20 cents each: 3 for $t 5$ cents; $\$ 1.30$ per 10 .

FORTUNE'S FORSYTHIA (Forsythia Fortunii). One of the best of the Forsythias. Growth upright, foliage deep green and covered with beautiful bright yellow flowers. Prices: 4 year plants, 2 to 3 feet, 35 cents each; 3 for 75 t

GOIDEN EIDER (Sambucus Aurea). A handsome variety with yellow golden foliage, very striking. We have a few large specimens t to 6 feet high at 75 cents each. Prices: 2-year plants 20 cents each; 3 for 50 cents; $\$ 1.25$ per 10 . 3 year plants 30 cents each; 3 for 75 cents; $\$ 2.00$ per 10.

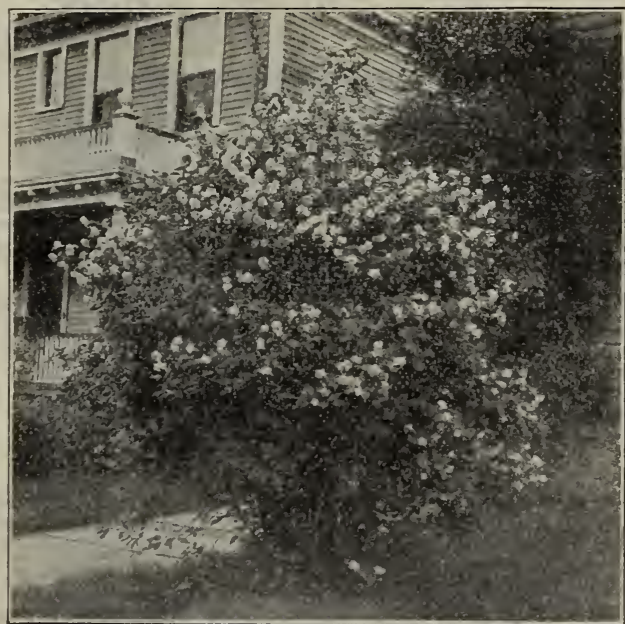

Garland Mock Orange.

FREE: 2 strong plants of Hydrangea P. G., 2-year plants, by mail postpaid, for names and addresses of 35 lome-owners. 


\section{A New American "Everblooming Hydrangea."}

This new American Hydrangea is believed to be the most beautiful hardy flowering shrub introduced during the last twenty years. It was found growing wild in the rocky hills of Western Pennsylvania several years ago, and finally was introduced into Central Ohio. From this introduction numerous plants have been grown and planted, so that many plants are now growing, three to five years old, and blooming profusely from early June till toward Autumn frosts. The illustration is from a photograph of a three-year old plant, taken June $18,1908$.

The plant, which attains a height of five or six feet, with nearly the same breadth, is of far more graceful habit than the old form; with large trusses of beautifully formed flowers of dazzling whiteness, rendering this a plant of peerless beauty. The profusion of bloom of this new Hydrangea is very

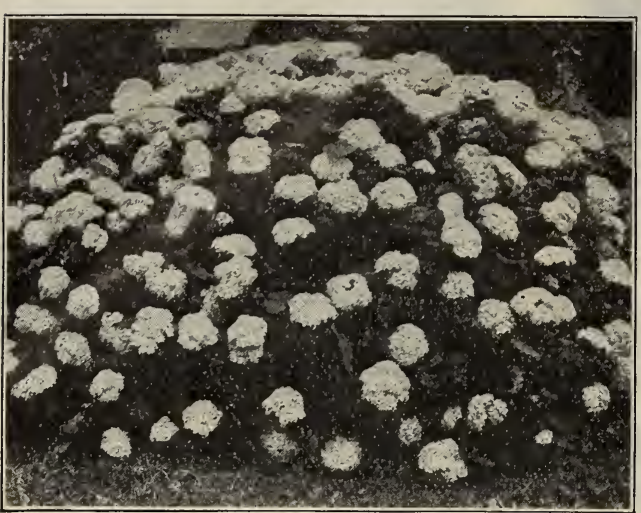

New Everblooming Hydrangea.

(Hydrangea Arborescens Sterilis.) unusual. There have been counted 100 good trusses on one plant-trusses $71 / 2$ inches in diameter and under. The flowers are um. beled instead of spiked, and bloom from June till September, or frost, thus coming nearly six weeks earlier than Hydrangea $P$. G. and lasting until after that has passed. The demand will be enormous and for that reason we do not wish to sell over 10 plants to each person. Prices: $1 \frac{1 / 2}{2}$ to 2 feet plants, 50 cents each; 3 for $\$ 1.40 ; \$ 3.75$ per 10.2 to 3 feet plants 75 cents each; 3 for $\$ 2.10 ; \$ 6.00$ per 10 .

THE BEAUTIFUI “ SNOWBERRY " (Symphoricarpus Rlba). This beautiful shrub is literally covered with pure white berries in the late Summer and Fall. Grows 4 to 6 feet in height, blooming in July and August. See illustration. Prices: Strong 2-year plants 15 cents each; 3 for 35 cents; $\$ 1.20$ per $10 ; \$ 8.00$ per 100 . $1 \mathrm{r} / 2$ to 2 feet plants 20 cents each; 3 for 45 cents; $\$ 1.50$ per $10 ; \$ 12.00$ per 100 .

CORAI BERRY OR INDIAN CURRANT (Symphoricarpus Rubra). A shrub of very pretty habit, and makes a delightful contrast with the snowberry. The berries are a dark rich red and are borne

in great profusion all over the bush. Prices: Strong 2-year plants 20 cents each; 3 for 40 cents; $\$ 1.25$ per $10 ; \$ 10.00$ per 100 . $11 / 2$ to 2 feet plants 25 cents each; 3 for 60 cents; $\$ 1.50$ per $10 ; \$ 12.00$ per 100 .

UPRIGHT HONEYSUCKLES (Lonicera).

The following species are of erect shrubby habit. The climbing sorts will be found under the head of climbing vines.

JAPANESE BUSH HONEYSUCKIE (Ionicera Morrowi). A fine variety from Janan and valuable for its wonderful foliage and handsome red fruit. Admirably adapted for ornamenting small or large grounds.

TARTARIAN HONEYSUCKIE (Ionicera Tartarica). Has pink flowers which contrast beautifully with the foliage. This and the Japanese Bush Honeysuckle appear to fine advantage when planted together. Prices: Two above varieties 20 cents each; 3 for 50 cents; $\$ 1.50$ per $10 ; \$ 12.00$ per 100 .

\section{RED BARKED SIBERIAN DOGWOOD. (Cornus Siberica.)}

A rare and remarkable variety with bright red bark in Winter. Very attractive. In the Spring it is covered with a very small delicate pure white flower. The popularity of this shrub is universal as it does well all over the country. Prices: Strong 2-year plants 20 cents each; 3 for 45 cents; $\$ 1.30$ per $10 ; \$ 10.00$ per 100 . $11 / 2$ to 2 feet 25 cents each; 3 for 60 cents; $\$ 1.75$ per $10 ; \$ 12.00$ per 100 . 2 to 3 feet 30 cents each; 3 for 75 cents; $\$ 2.00$ per $10 ; \$ 15.00$ per 100

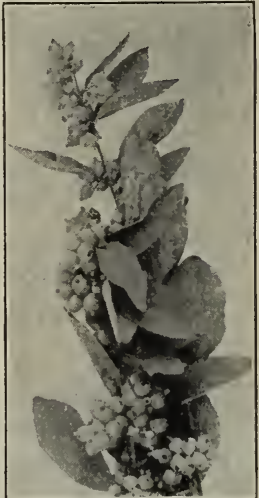

Snowberries.

BERBFRIS (Barberry). For Hedge Department see page 37.

\begin{tabular}{|c|c|}
\hline PANESE BARBERRY & PURPIE \\
\hline eris Thumbergi). One & Equally remarkable for its bril- \\
\hline shrubs & liant purple foliage and fruit. \\
\hline edging or & $\begin{array}{l}\text { Valuable as a border, hedge, or } \\
\text { as single specimens. }\end{array}$ \\
\hline in the $\mathrm{Fa}$ & Prices: Each \\
\hline & 2 in. \\
\hline$\$ 1.00$ & $1 \mathrm{x} / 2-2^{2} \mathrm{ft}$ \\
\hline$-1 \mathrm{1} / 2 \mathrm{ft} . \quad 1.75 \quad 15.00$ & 2.00 \\
\hline$/ 2-2 \quad \mathrm{ft} . \quad .25 \quad 2.00$ & 2.50 \\
\hline
\end{tabular}

STRAWBERRY TREE (Calycanthus Floridus). $\Lambda$ desirable shrub. The wood is fragrant, flowers of a rare chocolate color.

June. Prices: Strong 2-year plants 20 cents each; 3 for 50 cents; $\$ 1.40$ per 10 .

BURNING BUSF (Euonymus Atripurpurens). Foliage bright red, flowers deep purple. Prices: Strong 2-year plants 20 cents each; 3 for 50 cents; $\$ 1.45$ per 10 .

PEARI BUSH (Exochorda Grandiflora). Flowers pure white and have a delightful fragrance. 6 feet. Prices: 2-year strong plants 25 cents each; 3 for 60 cents; $\$ 1.30$ per 10 .
GRFFN BARBERRY $\Lambda$ handsome shrub suitable for lawn or hedge, with yellow flowers in May, followed by orange scarlet fruit. Prices: $1-1 \mathrm{x} / 2$ feet 20 cents each; 3 for 45 cents; $\$ 1.25$ per 10 .

SPECIAI OFFER No. 122

44 best shrubs

all strong 2-year plants.

10 Japanese Barberry

10 Purple Barberry

10 Snowberry

10 Red Dogwood

2 Hydrangea

2 Coral Berry

To go by Express, purchaser paying charges.

Price, $\$ 5.00$ 


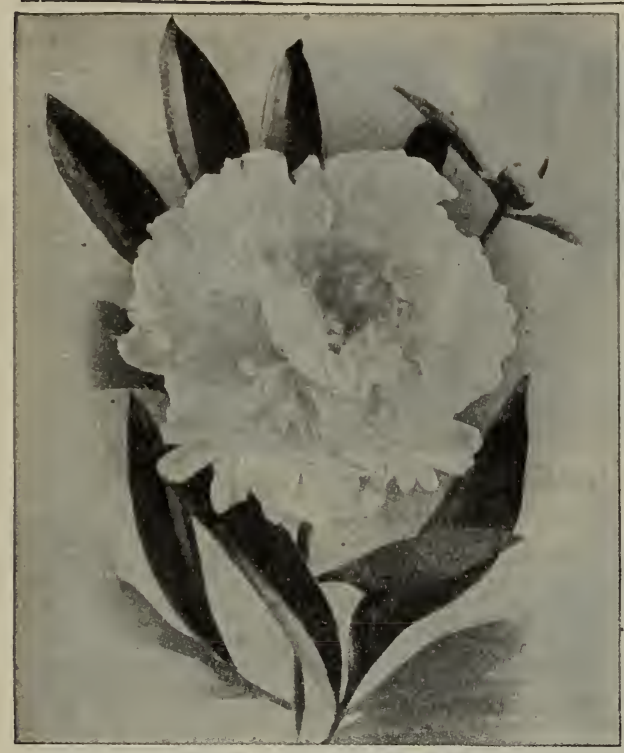

Peonies Rival the Rose.
CHOICE HERBACEOUS

\section{PEONIES.}

The Peony is today without a rival as a hardy garden favorite and is quite naturally so, as no other hardy garden plant probably thrives as well with as little special care and produces so fine a display of gorgeous blooms. The great diversity of color ranging from pure white to dark red very much increases their value. Our strong hardy plants if planted in mellow rich soil will give a fine display of blossoms the first season. The Peony is unquestionably the finest herbaceous perennial in the world. It rivals the Rose and when you look at a good big double one it is hard to see much difference. The three varieties which we offer give a wide range of color and are absolutely the hardiest and most popular varieties in cultivation today. Plant 3 feet apart.

FESTIVA MAXIMA. This is acknowledged to be the best white Peony in existence both in color and form. Of the purest white, splashed with a few streaks of crimson in the center. Prices: Large strong roots, 50 cents each; 3 for $\$ 1.40 ; \$ 4.50$ per 10 .

RUBRA SUPRRBA. Large, late, vigorous, sometimes called the red Festiva Maxima. Its bright red double blooms are gorgeous and make a delightful contrast to the pure white of the Festiva Maxima. Prices: Large roots, 75 cents each; 3 for $\$ 2.10$; $\$ 7.00$ per 10 .

COURONNE D'OR. The blooms are a beautiful sulphur yellow or golden color, with center petals bordered red. A strong vigor-
oots, 75 cents each; 3 for $\$ 2.00 ; \$ 6.50$ per 10 .

$\frac{\text { ous grower with large double blossoms. Prices: Strong roots, } 75 \text { cents each; } 3 \text { f }}{\text { BEAUTIFUL }}$

Flower lovers and gardeners know how indispensable are vines and climbers for beautifying one's place, especially near the louse. Plant Clematis, climbing roses and honeysuckles about the front porches, with perhaps a vine or two of the Chinese Wisteria to climb as high as the roof. Stone or brick walls are always prettier when ivy clad. Then going around to the rear of the house; if you have a trellis to cover, or want a screen for certain buildings, get more honeysuckles, and if you need something to cover a large space quickly, try the Kudzu vine. Below we give the best climbers for arbors, arches, trellises, porches, etc. Remember how pretty an arbor can be.

CIEMATIS PANICUIATA. This is by far the most popular climbing vine we have. It is of very rapid growth, quickly covering trellises and arbors with handsome clean glossy foliage, which is of that healthy green color that so few of this class of plants possess. The flowers are pure white, borne in immense sheets, almost completely hiding the foliage, and of a most delicious fragrance. It flowers in September when few other vines are in bloom. Prices: 2 $\$ 3.35$ per 10 . 35 cents each; 3 for $\$ 1.00$;

CIEMATIS JACKMANNI. This variety, with its strong healthy growth, hardy nature and rich deep velvety-purple flowers, is extremely popular. Prices: 2 year plants, 40 cents each; 3 for $\$ 1.10 ; \$ 3.75$ per 10 .

THE JAPAN OR BOSTON IVY (AMpelopsis Veitchii). The grandest hardy climbing vine in existence, for covering houses, churches, schools, etc. Its glossy ivy leaves overlap each other, and its long delicate young shoots stretch up the walls with free and rapid growth. Prices: $\delta$ year plants, 30 cents each; 3 for 75 cents; $\$ 2.75$ per 10.

PURPIE CHMNESE WISTERIA. A rapid growing, tall vine with handsome foliage and flowers. The purplish pea-shaped flowers are profusely borne in immense drooping clusters 7 to 12 inches long. Prices: 2 years, 35 cents each; 3 for $\$ 1.00$.

WHITE CHINESE WISTERIA. Same form and habit of growth as the above, with pure white flowers. Prices: 50 cents each; 3 for $\$ 1.40$.

HAII'S JAPAN HONEYSUCKIE. One of the best climbing vines in the list. It is nearly evergreen, its foliage retaining its green color nearly all winter. Its main feature is its beautiful yellowish-white flowers, which are so deliciously fragrant as to be noticed for miles. Grand for porches, trellises, arbors and fences, also ground cover. Prices: 2 year plants, 25 cents each; 3 for \begin{tabular}{l}
70 cents; $\$ 2.25$ per 10 . \\
\hline
\end{tabular}

\section{OTHFR CIIMBING VINIS.} Am. Trumpet Vine. $4 \mathrm{ft}$., $15 \mathrm{c}$ each, 3 for $40 \mathrm{c}$ Dutchman's Pipe. 2 yr., $50 \mathrm{c}$ each, 3 for $\$ 1.25$. Matrimony vine. Strong, $30 \mathrm{c}$ each, 3 for $75 \mathrm{c}$ Kudzu Vine. Strong roots, 35c each, 3 for $\$ 1.00$.

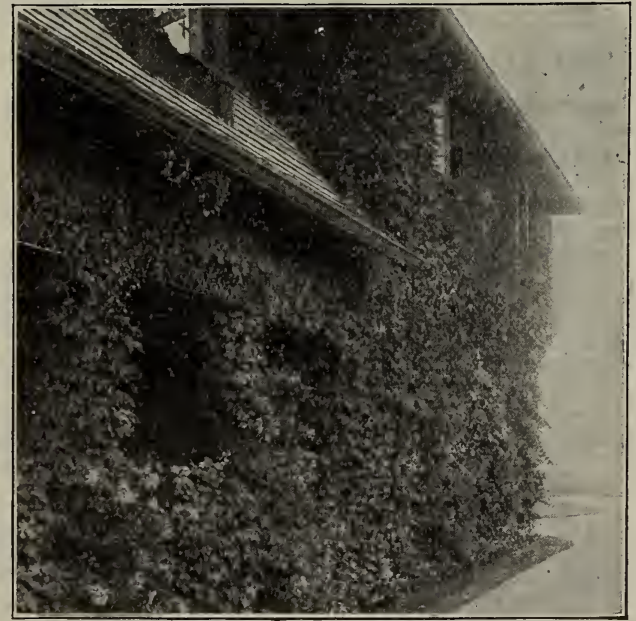

A Cool Place on a Hot Summer Day. 


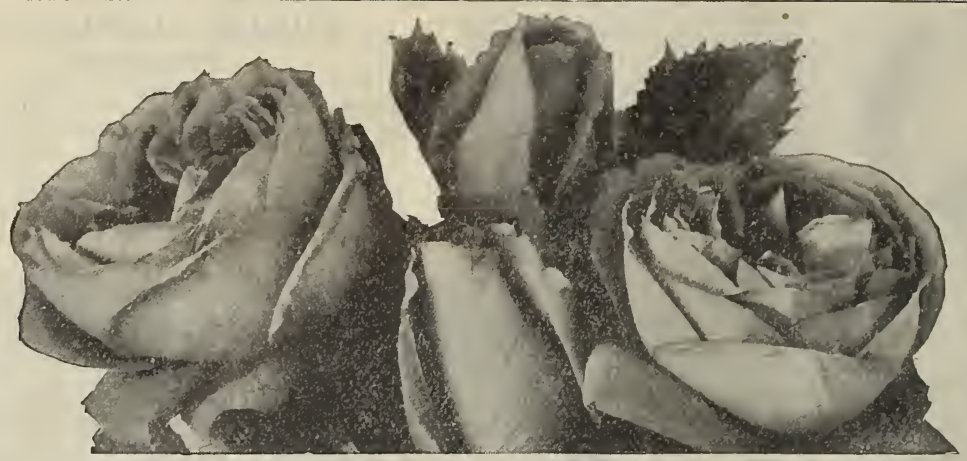

Hill's "High Quality" Roses.

In order to supply the incrcasing demand for Roses, we have enlarged our facilities and are now propagating plants on a more extensive scale than ever. Roses arc the most important flowering shrubs we have-the mere name is an inspiration to garden lovers. No home or garden is complete without them, no arrangements satisfactory that neglect them; in fact they are indispensable. Our immensc stock and great variety of hardy roses enable us to furnish assortments adapted to various purposes, and intending purchasers are invited to examine our lists and whenever we can be of any assistance in making selections our services will be cheerfully given. Our plants are all strong, field grown bushes, and arc absolutely guaranteed to make a sturdy growth and produce a profusion of bloom the first season. It is the quality of our roses alone which makes this guarantee possible. The fact that we ship our plants to ncarly all the large estates throughout the country is proof positive of the quality of our stock.

Dear Sir: The shipment of rose bushes arrived yesterday and I wish to take this opportunity of expressing to you my appreciation, not only of the extremely high grade of stock furnished, but also of the excellence with which the package was prepared and the business-like way in which you handled the entire order. I have purchased a great many plants from different concerns in the past, but these a'ere positively the finest I have ever received.-Hugh Munro, St. Paul, Minn.

\section{Garden Hybrid Roses-Strictly Hardy.}

This class of roses blooms profusely in June and at intervals throughout the Summer and Fall. The popular hardy garden roses mostly belong to this class and are always satisfactory. Do not allow roscs to suffer for want of plenty of fertilizer, as they are gross feeders, and only when they have plenty to fced on can they be expected to produce the best results. Prices of Roses except where noted, 35 cents each; \$3.00 per 10; \$27.50 per 100 .

ANNE DE DIESBACF. Raised from La Reine. Color, bright carmine. A beautiful shade, very large.

ALFRED COIOMB. A brilliant carmine crimson, very large, full and of fine globular form.

AMIERICAN BEAUTY. Well known as one of the grandest and most beautiful roses in cultivation. Immense buds and flowcrs of rich glowing crimson color. Prices: 40 cents each; $\$ 3.75$ per 10 .

BARONESS ROTHSCFIID. An exquisite shade of rich satiny pink. Very symmetrical, distinct and beautiful.

CIIO. Flowers large, of fine globular form, flesh color,

GENTRAI WASHINGTON. Color bright crimson, fading in the sun; very large and full.

IMARGARET DICISON. Very large, bcautiful, white.

FISHER HOIMES. A very beautiful and valuable rose, decp crimson.

FRAU KARI DRUSCAKI. This magnificent variety has takcn first prizes at all the great flower shows of Europe, and is undoubtedly one of the grandest hardy pure white roses ever introduced. Prĩces: Fine plants, 40 cents each; $\$ 3.50$ pcr 10 .

GENERAI JACQUEMINOT. Famous the world over as one of the most magnificent hardy crimson roses ever introduced. Large, vcry fragrant, soft red.

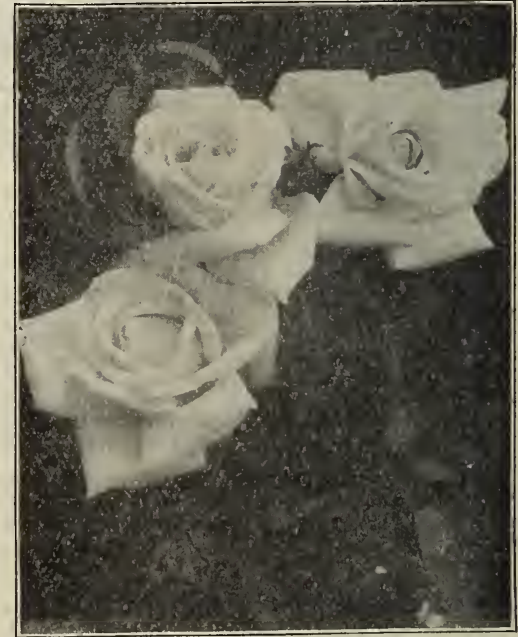

Frau Karl Druschki.

\section{Special Offer No. 123}

1 Anne De Diesbach

1 Alfred Colomb

1 Fisher Holmes

2 General Jacqueminot

1 Frau Karl Druschki
$\$ 2.00$ for the six.
PARSONS ON THE ROSE.

By Samuel B. Parsons.

$A$ treatise on the propagation, culture and history of the rose. Ncw and revised cdition. $5 \times 7$ inches. Cloth.

Price $\ldots \ldots \ldots \ldots \ldots \ldots \ldots \ldots \ldots . . \ldots$ 


\section{Superior Garden Hybrid Roses}

The Cream of This Splendid Class.

1 GENRRAT JACQUEMINOT, Crimson. Very fragrant. Extra large.

1 FRAU KARI DRUSCHKI. White. 'The very best white rose.

1 AMERICAN BEAUTY. Red. Mlost popular rose grown.

1 PAUI NEYRON. Pink. Has largest blooms of any rose in cultivation.

Special Offer No. $124 \begin{aligned} & \text { Above four superior roses. Strong. field-grown. } \$ 1.25 \\ & \text { Guaranteed to bloom the first year. BY EXPRESS } \$ 1.25\end{aligned}$

\section{Garden Hybrids (Con.).}

PAUT NEYRON. A magnificent rose; one of the largest and finest of all; clcar, shining pink; very double, full and fragrant.

IMAGNA CEARTA. In old favorite.

Large doublc flowers. Rosy red flushed crimson.

MRS. JOHN IAING. Soft pink, of beautiful form, exceedingly fragrant and a remarkable bloomer. JUIES MARGOT.

TIN. Cherry red. Splendid form.

J O H N HOP-

PER. An excellent rose; hardy and an abundant bloomer: solid and regular flowers, perfectly double, clear bright rosy pink, very fragrant.

IM D A I I G A B R I I I IUIZET. rose suffused with lavender and pearl. Superb. (Budded.)

IMAD. PI. A N TIER. Pure white, large and double. Extremely hardy and strong growing.

MARCIONESS OF IORNE. Free-flowering. Large sweet and full. Rich rosy color. Center carmine.

IV A R IA I I P. WITDER. Large, well-formed; color, cherry carmine.

PRINCE CAMIIIE DE ROHAN.

Rich crimson-maroon, almost black.

Large and full.

UIRICF BRUNNGR. Rich glow

ing crimson, flamed scarlet. Large, full, long stemmed. Hardy.

VICK'S CAPRICE. Full and deep. Color satiny pink, striped and dashed with white and bright carmine. Splendid.

\section{Make a Beauty Bed of} Choice Everblooming Roses.

Think of the joy of having a beautiful bouquet of roses on your table, fresh ones almost every day throughout the summer. These are the kind of roses you want.

FIII'S "BEAUTY BED" COTIECTION.

12 above roses, two each of six varieties, our selection. Enough to fill a bed $6 \times 10$ feet. Plant three feet apart. Pig sized bushes, to go by Express. Price \$2.95.

\section{Hybrid Tea Roses.}

Very free bloomers; hardy with slight protection. These delightful, delicately formed and fragrant roses are very popular as they bloom profusely all the growing scason, and are ideal in form, color, fragrance and foliage.

BABY RAMBIFR. The rose hybridists certainly made a remarkably happy combination when they succeeded in creating this wonderful new rose. Imagine a bushy rose just right for the flower garden or a pot plant as to size, with all the beauty ters of the Crimson Rambler, and add to this that it will bloom constantly all summer. Perfect in form and color. CTOTRIIDE SOUPERT. Medium size: very double and beautifully imbricated, produced in clusters; pearly white.

TAISFRIN AU G U S TA $\mathbf{A}$ A TORIA. An exquisite white variety faintly blended with cream color; very large, full and double, almost perfect in form. 35 cents each; per $\$ 3.00$.

KILIARNEY. A charm. ing rose of robust habit; blooms large, buds long and pointed. Color pink.

IA FRAINCE. Delicate silvery rose, changing to silvery pink; very large, full, of fine globular form; a most constant bloomer.

IMME. ABEI CHATENAY. Superb; frce-blooming; the best of its color; rosy carmine, shaded darker. A grand grower. Hardy. 35 cents each; per $10, \$ 3.00$.

\section{Price of Hybrid Tea Roses.} (Except where noted.)

Very strong field grown. Each, 30 cents; per $10, \$ 2.75$; per $100, \$ 25.00$.

\section{Special Offer No. 125}

2 each of three varieties from above, our selection, 6 big strong bushes. Price, $\$ \mathbf{1 . 5 0}$.

OUR SFIFCTION. Where the purchaser desires to leavc the selection to us, we will take special care in selecting the finest sorts, including a wide diversity of color, and will send kinds we would prefer were we buying. 


\section{The Beautiful New Rugosa Rose}

\section{Nova Zembla. White.}

This beautiful new Rose is a sport of the Conrad Ferdinand Meyer. It is absolutely liardy. Makes a fine bush and flowers as early as its parent. The wellshaped double flowers are pure white and very sweet scented. Bright shining green leavcs elegantly veined. Although dwarf it is a healthy, vigorous grower, entirely hardy and a constant and abundant bloomer. It has been highly spoken of by the leading Rose growers of this country and Europe as the most beautiful and satisfactory Snow White Rugosa Rose ever produced. Orders will be filled strictly in rotation until stock is exhausted. Prices: Strong field-growin plants, each 50 cents; per 4 , $\$ 1.90$; per dozen, $\$ 4.50$.

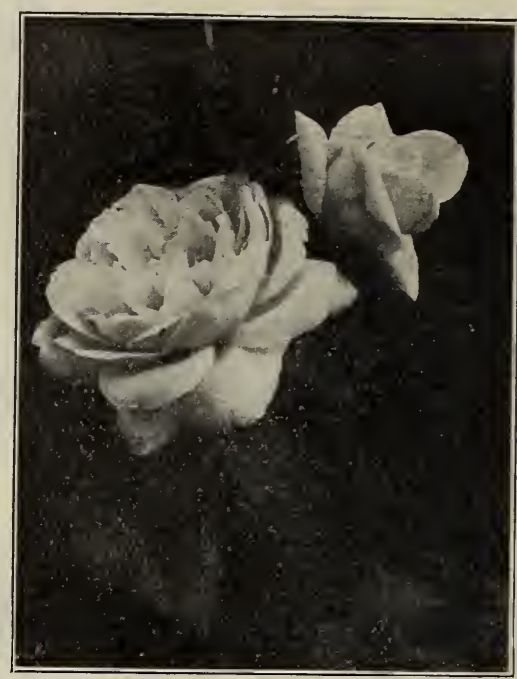

New Rose-Nova Zembla.

\section{Beautiful Everblooming Climbing Roses.}

We make a specialty of Climbing Roses-because their remarkable merits entitle them to a place in every garden. The rose-loving public is gradually awakening to the fact that this class is almost indispensable for homc planting. All bloom with the greatest freedom, and there is scarcely a day during the growing season that they are not blooming. And such flowers! They are simply exquisite and it is difficult to say which is the prettiest. Ccrtain it is that of all roses, Climbing Roses are among the cheapest, best and most satisfactory for general planting. Here are offered the best now in cultivation PRICES ON AII CIIMBING ROSES unless otherwise specified are 30 cents each; per 10 ,
$\$ 2.75 ;$ per $100, \$ 25.00$.

CRIMSON RAMBTER. The most popular Rose in cultivation. One of the greatest Climbing Roses of its color in existence, the plants making a growth of 10 to 20 feet in a single season, producing in wonderful profusion large trusses of deep glowing crimson flowers. When in full bloom it is a vivid mass of crimson beauty. Perfectly hardy everywhere.

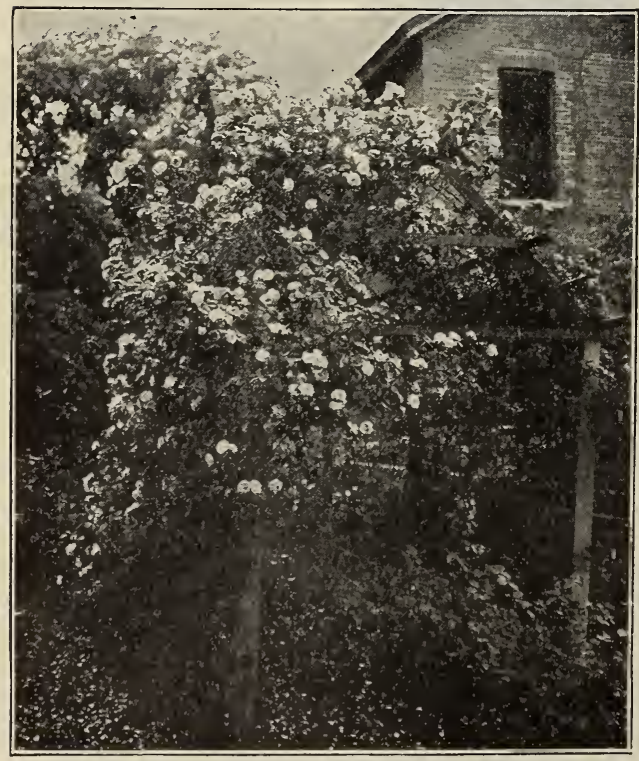

DOROTHY PERKINS. This is a grand new variety so hardy as to withstand the most severe winters with impunity. Grows 10 to 15 feet in a season. Flowers are perfectly double with petals crinkled and are borne in clusters of ten to twenty that cover the bush for several weeks in the Spring. Blooms just in time for June weddings, and because of its abundance of bloom is a most valuable Rose for cutting and decorating.

QUEEN OF THE PRAIRIE. Bright rosy red frequently striped with white. Very large, compact and beautiful. Will thrive in any part of the United States and should be in every collection.

BAITIMORE BELIE. A rapid growing dark leaved prairie Rose. Blooms in large clusters of pale blush and white flowers late in the season. It is an exceedingly beautiful Rose and perfectly hardy.

IMPRESS OF CHINA. A hardy rapid growing Rose of graceful twining habit and few thorns. Bears fragrant flowers of soft rich red, shading to cherry pink. Very pretty.

\section{Special Offer No. 126}

2 Crimson Rambler

1 Dorothy Perkins

1 Baltimore Belle

STRONG PUANTS PRICE

$\$ 1.10$ 


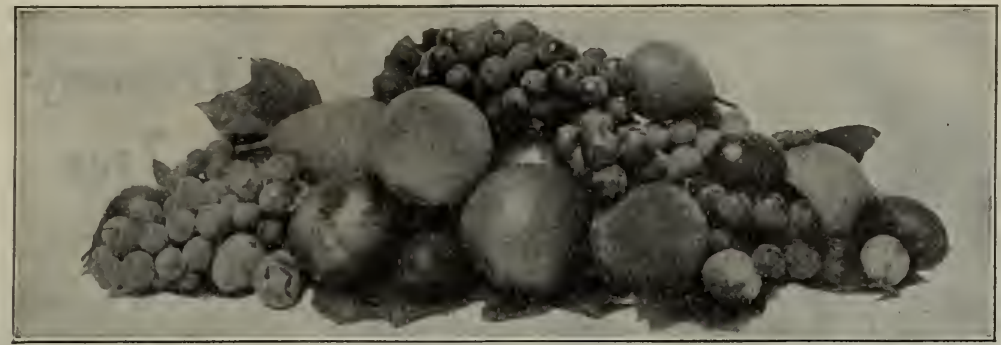

\section{Apples.}

Do you want to know the secret of growing big crops of large luscious apples? To successfully grow them you must, above all things, start right. Get large, strong, healthy, standard size trees, 5 to 7 feet tall. This applies to Cherries, Plum, Peach, Pears, etc., just as much as it does to Apple trees. The following hints will prove valuable whether you are planting large commercial orchards, or a few trees for home fruit garden.

\section{HINTS ON TRANSPLANTING, ETC.}

We cannot attempt to give complete directions on all points connected with Tree Planting, but simply a few hints on the more important operations. Every man who purchases a bill of trees should put himself in possession of "Successful Fruit Culture" (see page 32), or some other treatise on tree culture, that will furnish him with full and reliable instructions on the routine of management. Transplanting is to be considered under the following heads:

1st. The Preparation of the Soil. For fruit trees the soil should be dry, either natural or made so by thorough drainage, as they will not live or thrive on a soil constantly saturated with stagnant moisture. It should also be well prepared. On new, fresh lands, manuring will be unnecessary; but on lands exhausted by cropping, fertilizers must be applied, either by turning in heavy crops of clover, or well decomposed manure or compost. To ensure a good growth of fruit trees, land should be in as yood condition as for a crop of wheat, corn, or potatoes.

2nd. The Preparation of the Trees. In regard to this important operation, there are more fatal errors committed than in any other. As a general thing, trees are planted in the ground precisely as they are sent from the Nursery. In removing a tree, no matter how carefully it may be done, a portion of the roots are broken and destroyed, and consequently the balance that existed in the structure of the tree is deranged. This must be restored by a proper pruning, adapted to the size, form, and condition of the tree, as follows:

STANDARD ORCEARD TREES. These, as sent from the Nursery, vary from five to seven feet in height, with naked stems or trunks, and a number of branches at the top forming a head. These branches should all be cut back to within three or four buds of their base. This lessens the demand upon the roots, and enables the remaining buds to push with vigor. Cut off smoothly all bruised or broken roots up to the sound wood. In case of older trees, of extra size, the pruning must be in proportion; as a general thing it will be safe to shorten all the previous year's shoots to three or four buds at their base, and where the branches are very numerous some may be cut out entirely.

3rd. Staking. If trees are tall and much exposed to winds, a stake should be planted with the tree, to which it should be tied in such a manner as to avoid chafing. A piece of matting or cloth may be put between the tree and the stake.

4th. Mulching. When the tree is planted throw around it as far as the roots extend, and a foot beyond, five or six inches deep of rough manure or litter. This is particularly necessary in dry ground, and is highly advantageous everywhere both in spring and fall planting. It prevents the ground from baking or cracking, and maintains an equal temperature about the roots.

5th. After-culture. 'The grass should not be allowed to grow around young trees after being planted, as it stunts their growth. The ground should be kept clean and loose around them, until, at least, they are of bearing size.

\section{Select Apples.}

Our principal stock of Apples consists of the following varieties, and can be recommended as the best now in cultivation.

PRICES OF APPIE TREES (also Crab): 5 to 7 feet, 35 cents each; $\$ 2.50$ per $10 ; \$ 18.00$ per 100.4 to 6 feet, 25 cents each; $\$ 2.00$ per $10 ; \$ 15.00$ per 100 .

\section{SUMMER APPLES.}

RED ASTRACHAN. Large, roundish, nearly covered with deep crimson, over-spread with a thick bloom, very handsome, juicy, good though rather acid. The tree is very hardy, a free grower, with large foliage, and a good bearer; highly esteemed on account of its fine appearance, earliness and hardiness. August.

DUCHESS OF OIDENBURG. A large, beautiful Russian apple; roundish, streaked red and yellow; tender, juicy and pleasant. A kitchen apple of best quality, and esteemed by many for the dessert. Very hardy; succeeds well in the Northwest, where most varieties fail. August and September.

YEIIOW TRANSPARENT. Supposed to be of German origin. It is the earliest summer apple, medium size, pale yellow, very tender flesh, and of good quality. A free grower. Early August. 

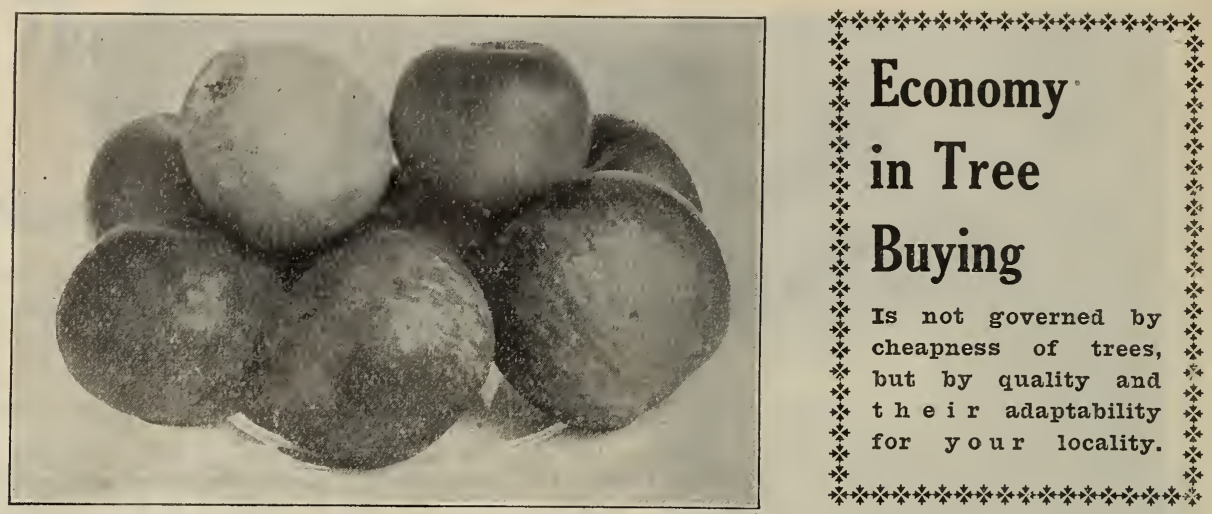

FALL APPLES.

For Prices on Apples, కee Page 31.

WIAITHY. A very valuable variety for general planting. Will succeed anywhere because exceptionally hardy. Fruit large, red, fine and juicy. From three to four years from planting will bear from one-half to two bushels per tree. One of the best. Tree very thrifty. A free grower and productive. A variety of much value on account of its great hardiness and good quality.

FAMEUSE (SINOW APPLE). Medium size-deep crimson. Flesh, snowy white, tender, melt ing and delicious. Tree vigorous with dark wood. Succeeds well anywhere, but particularly in the north.

MAIDENS BIUSIE. Large, flat, pale yellow with red cheek; beautiful, tender and pleasant A good bearer.

FAII PIPPIN. Very large, roundish, oblong, yellow, rich and delicious. Tree a free grower, spreading and fine bearer. An admirable baking apple.

\section{WINTER APPLES.}

BAT,DWIX. Large, bright red, crisp, juicy and rich. Tree vigorous, upright and productive in New England, New York, Ontario and Michigan. Popular for table or market.

BEN DAVIS. A large, handsome, striped apple of good quality. Tree very hardy, vigorous and productive. A late keeper. Fighly esteemed in the west and southwest.

GOIDEN RUSSET. Medium size, dull russet with a tinge of red on the exposed side. Flesh, greenish, crisp, juicy and highly flavored. Tree a vigorous grower.

GRIMISS GOIDEN. Medium to large size. Skin, golden yellow. Flesh, crisp, tender and juicy. Very good. Tree hardy and vigorous.

JONATIAN. Medium size, red and yello'v. Flesh, tender, juicy and rich. A moderate grower. Very productive. One of the best varieties either for table or market.

NORTHFRN SPY. Large, red striped. Flesh, juicy, rich, retaining its freshness of appearance and flavor til! July. The tree is a remarkably rapid, erect grower and a great bearer. One of the finest late keeping apples.

PFWAUKEF. Fruit medium to large. Skin, bright yellow, striped and splashed with red. Esteemed especially for cold climate on account of its hardiness.

TOrMAN'S SWErT. Medium size. Pale whitish yellow, slightly tinged with red. Flesh, firm, rich and very sweet. Excellent for cooking. Tree a free grower, upright and very productive.

WINE SAF. Large. Roundish. Deep red. Medium quality. Keeps well. Tree a moderate grower and good bearer. Succeeds well in the west and is there valuable and popular.

YORK IIMPERIAI. Medium, whitish shaded with crimson in the sun. Firm, crisp, juicy, pleasant mild sub-acid. Tree moderately vigorous and productive.

NORTHWESTERN GREENING. Fruit large, round, conical. Color, greenish yellow. Flesh, white. Tree splendid grower and hardy as Wealthy.

GANO. Good size and smooth. Deep red. Very attractive. Fine grained and tender flesh with mild sub-acid flavor. Good shipper and keeper. Tree healthy, vigorous and hardy.

\section{CRAB APPLES.}

\section{Price Same as Other Apples.}

The improvements in the varieties of crab apples have kept pace with other kinds of fruit. A few years ago it was thought fit only for cider, preserves and jelly, but there are varieties now that command a good price on the market for dessert purposes. Especially is this the case with the Whitney. Ornamental when in bloom and when loaded with highly colored fruits. They are entirely hardy and do mental when in bloom and the most exposed situations. They come into bearing very early, generally the second year and bear every year. They are unequalled for jelly and can be dried, cooked, canned and preserved with the skin on thus saving work.

WHITNEX, NO. 20. Large, averaging $1 \mathrm{~T} / 2$ to 2 inches in diameter. Smooth, glossy green splashed with carmen. Flesh, firm, juicy and rich. $\Lambda$ great bearer and hardy. Hardy.

HYSIOP. Large size. Dark crimson with bloom very showy and most beautiful of all the class.

SUCCESSFUI FRUIT CUITURE $\Lambda$ practical guide to the cultivation and propagation of fruits, By Samuel T. Maynard. Illustrated, 274 pages, $5 \times 7$ inches. Cloth, $\$ 1.00$, 


\section{Pears.}

The following list includes most of those which have bcen wcll tcsted and proven valuable.

GATHERING PEARS. Une of the most important points in the management of Pears is to gather then at the proper time.

Summer Pears should be gathered at least ten days before they are ripe, and Autumn Pears, at least a fortnight. II inter varieties, if they will hang so long, may be left until the leaves begin to fall.

Thin the fruit. We cannot urge too strongly the following suggestion; when pear trees are heavily laden the fruit should be thinned when about one-third grown; else the fruit will be poor and the trees injured.

Price of Pears: Standard size, 5 to 7 feet, 50 cents each; $\$ 3.75$ per $10 ; \$ 25.00$ per 100 .

\section{SUMMER PEARS.}

BARTIETI. One of the best and most popular. Large; yellow and red; juicy, buttery, ripening in September.

CLAFP'S FAVORIT工E. A splendid Pear, resembling the Bartlett and ripening a few days earlier. The tree is hardy and vigorous.

\section{AUTUMN PEARS.}

FIEMISH BEAUTY. A large beautiful melting sweet Pear. The tree is very hardy, vigorous and fruitful.

KEIFTER. Very large; skin rich golden yellow. Tree vigorous; an early and a great yielder. Ripens in November.

Bartlett Pears.

WINTER PEARS.

ANJOU. A large handsome Pear with good flavor; keeps into midwinter. Tree a vigorous grower and good bearer.

IDAFO. A native of Idaho. Yellow with red cheek, covered with spots. The shape is more that of an oblong apple than a pear.

\section{DWARF PEARS.}

We can furnish Bartlett, Anjou, Clapp's Favorite, on dwarf stock. Dwarf Pears are grown on Quince stock and come into bearing sooner than the standards. Strict attention to them and high cultivation will result in a magnificent yield of fruit. Prices of Dwarfs are same as standards.

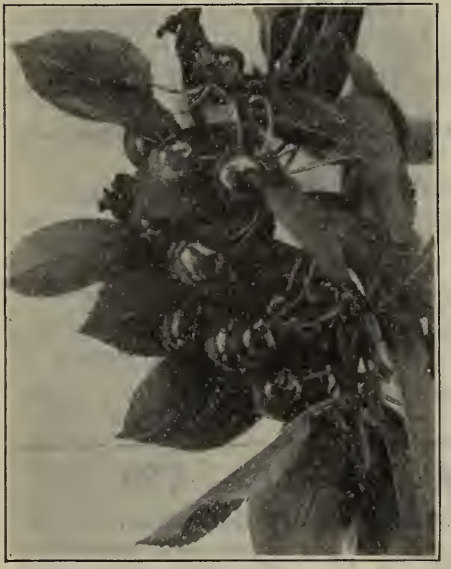

Early Richmond.

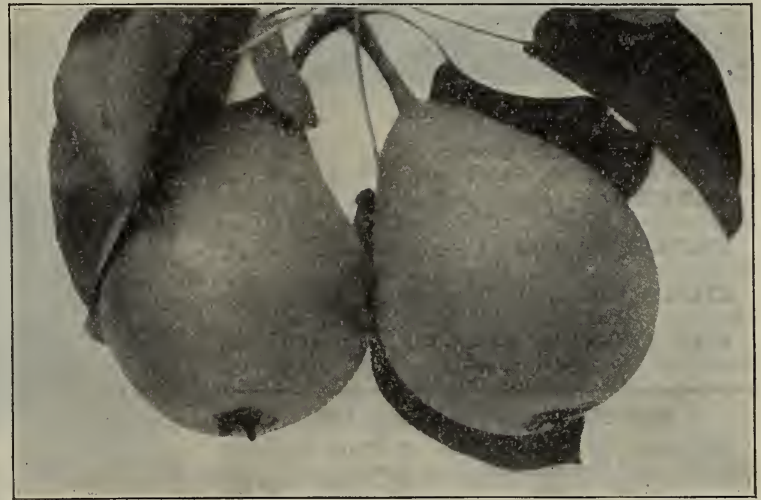

Iieffer Pear.

\section{Cherries.}

Cherries are of a rapid growth, producing large crops of luscious sweet fruit. We know of nothing in the fruit line that has been giving or promises to give in the future larger returns than the cherry orchard. Prices of cherry trees: Standard trees, 4 to 6 feet, 50 cents each; per dozen, $\$ 4.50$; per $100, \$ 40.00$

FARTY RICHINOND. Medium sized; dark red; juicy rich acid flavor. A very early and sure bearer. One of the most valuable and popular cherries we have. A grand market cherry and every home orchard should include the Early Richmond. Does well everywhere.

MONTMORENCY. A cherry of the Richmond class, but larger and more solid. Ripens from ten to twelve days later than the Early Richmond.

ENGISF MORELIO. Fruit large; dark red, nearly black; tender, juicy, sub-acid; valuable for preserves; tree small, slender growth; very productive.

DO NOT CONFUSE the price of Hill's standard size Fruit trees with the cheap prices quoted by some on seedlings or mailing size trees. The high reputation and good name Hill's trees have made for themselves throughout the entire country was not made in a day, a year or ten years. For over half a century have we been growing and shipping high grade Nursery products all over the United States, and we will not lower our reputation by sending out small. spindling, undersized, "Mailing Size" Stock. HIII'S TREES are absolutely the best that can be grown.

FRUIT FOR THE FOIME should be the first thought of every farmer, of every. Suburban Home owner, in fact of everyone having a lot or garden large enough for a few trees. Nothing is more healthful or will afford so much pleasure and profit for a small outlay than fruit. 


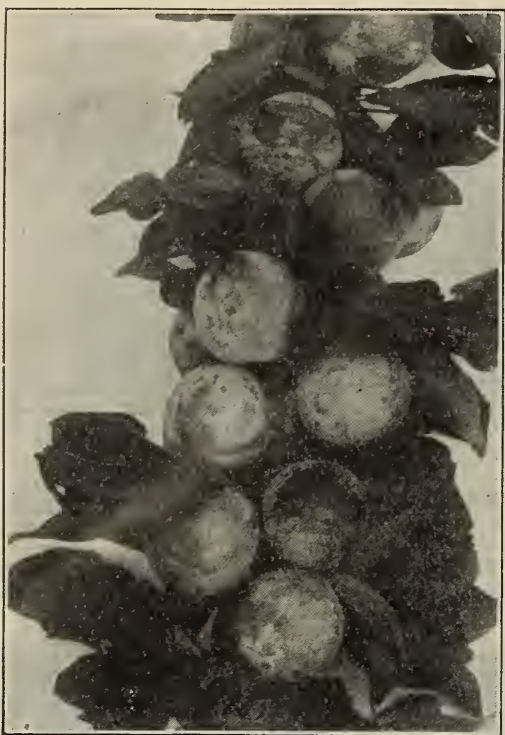

Burbank's Plum.

Price of Peach Trees: 4 to 5 feet, 25 cents each; per $10, \$ 2.00$; per $100, \$ 18.00$.

IIBERTA. Large; yellow with red cheek, of excellent quality. Freestone. Ripens July.

HAIE'S EARIY. Medium size; flesh, white, first quality. Ripens August.

HIII'S CFIII. Skin yellow, shaded with dark red; flesh, melting, sweet. September.

CRAWTORD'S EARIY. A magnificent, large, yellow peach, good quality. September.

SPECIAI OFFER No. 127.

Two each of two varieties of Plum and two varieties of Peach, and one variety of Crab Apple, our selection. Ten trees in all. \$2.60

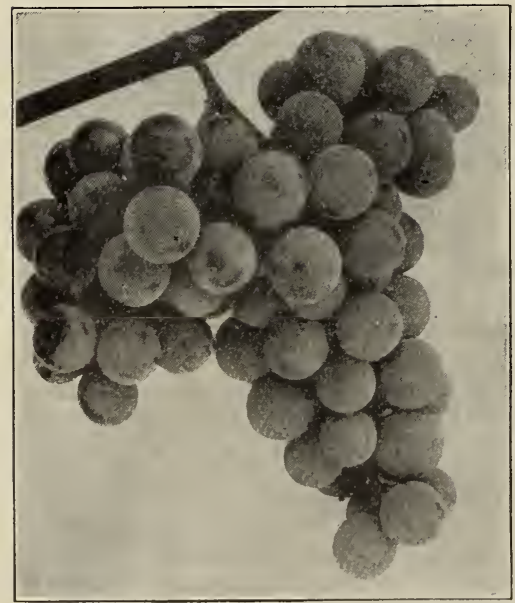

Concord Grapes.

\section{Plum.}

The Plum delights in a cool, not too dry situation, and good, rich soil. The varieties we offer have been thoroughly tested, and are standbys. These may be relied upon to furnish yearly crops of this most highly profitable and exceedingly delicious fruit.

Price of Plums: 4 to 5 feet, 40 cents each; $\$ 3.50$ per $10 ; \$ 25.00$ per 100 .

BURBANK'S JAPANESE PIUM. One of the most popular. Fruit conical and very large. Color, dark metallic red. Flesh, yellow, firm and juicy; flavor, rich and sugary.

ABUNDANCE. Fruit large and roundish; a rich cherry color with a whitish bloom. Flesh, light yellow.

WIID GOOSE. Fruit medium to large, rich golden yellow shaded with red.

IOMBARD. One of the most extensively grown. Color, purplish. Flesh, yellow.

HAWKEYE. One of the largest, best and most profitable market plums grown in the Northwest. Fruit, large; splendid shipper.

GREFN GAGE. One of the oldest known varieties. Fruit medium. Color, greenish yellow.

\section{Peaches.}

To secure fine fruit, give them an occasional dressing of wood ashes. Prune and mulch every Spring.

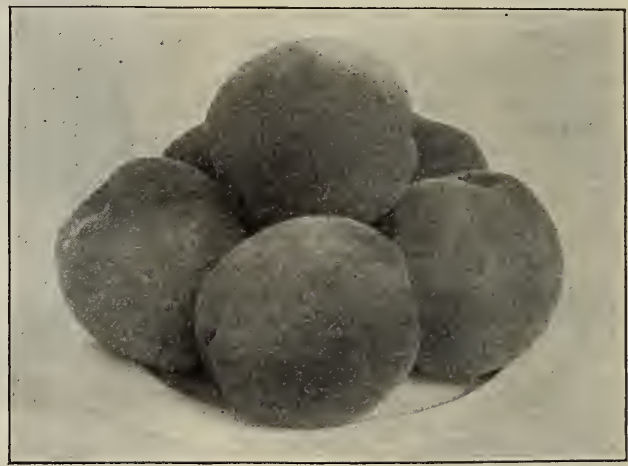

Flberta Peaches.

Grapes.

No part of the fruit garden yields a richer harvest than the vineyard. Along almost any garden fence or walk there is room for vines enough to furnish luscious grapes from July to November.

Price of Grapes: 2 years, No. 1,15 cents each; per $10, \$ 1.20$; per $100, \$ 10.00$.

\section{BLACK GRAPES.}

CONCORD. Early, decidedly the most popular grape in America, and deservedly so. Flesh, juicy, sweet, tender.

WORDIN. Bunch large, berries very large. Ripens 5 to 10 days earlier than the Concord.

MOORE'S EARIY. Berries extremely large and flavor is exquisite. Produces heavy crops. Ripens 15 days before the Concord.

CIINTON, Bunch small to medium, and compact. Is used principally for wine.

\section{Special Offer No. 128}

\section{Fill's Fome vineyard Collection.}

3 Concord, 2 years, No. 1) These will astonish

2 Brighton, 2 years, No. 1$\}$ you with their thrift 2 Niagara, 2 years, No. 1 and sturdiness.

\section{Price, 95c}




\section{RED GRAPES.}

AGAWAM. Color red or maroon. Flesh tender and juicy. Vine a good grower and bearer.

BRIGHTON. Coppery red, bunches large. Flesh rich, sweet and of the best quality. Ripens early.

DELAWARE. One of the finest of our native grapes. Bunches small and compact; berries small; light red.

\section{WHITE GRAPES.}

NIAGARA. Color pale yellow when fully ripe, sweet and of splendid quality. Ripens with the Concord.

POCKINGTON. Bunch large, berries roundish, bright golden yellow when fully mature, juicy and of good quality.

MOORE'S DIAMOND. I pure native, bunch large, compact berries, medium size. Vine vigorous.

For prices on grapes, see Page 34 .

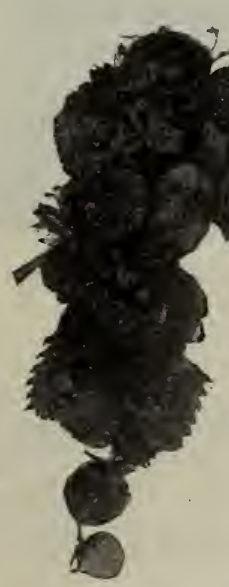

\section{STRAW-}

BERRIES.

The first fruits to ripen in the Spring, its temptin $g$ appearance, delicious $t$ a s t e a n d wholesome. ness as a diet, have made them universally popu-

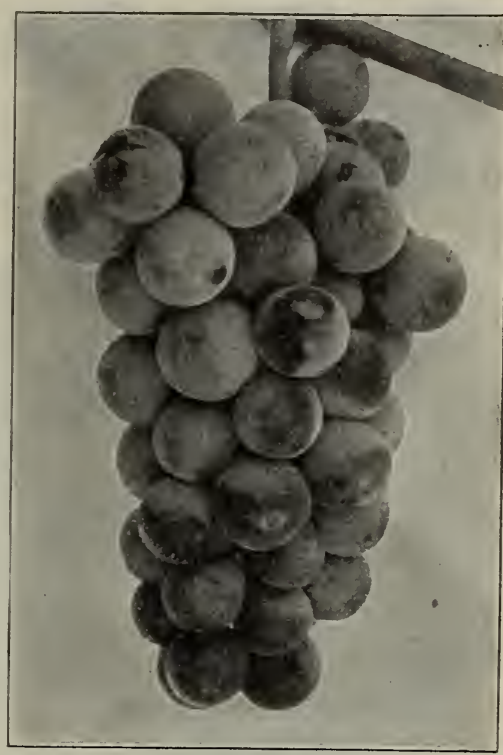

Brighton Grape. lar. It has been aptly named the "Queen of Small Fruits." The blossoms of all varieties marked " $\mathrm{S}$ " are bi-sexual or perfect, those marked " $\mathrm{P}$ " are destitute of stamens and are termed pistillate or imperfect. Imperfect varieties should have a row of perfect flowered sorts planted every third or fourth row to pollenize their blossoms. When imperfect blossoms are profusely fertilized they are the most prolific.

Prices of Strawberries: 25 cents per $10 ; \$ 1.00$ per $100 ; \$ 5.00$ per 1,000 .

BFDFRWOOD (S). Early, a very strong yielder, and continues a long time in bearing. The fruit is good size and as firm as the Crescent.

BUBACF (P). A well known variety, noted for its large size and productiveness. Mid-season in ripening. Especially recommended for home use or near market.

BRANDYWINE (S). Very vigorous growing plant and productive. Medium to large berries. Ripens medium to quite late.

CRESCENT (P). Succeeds well everywhere. Plant small; berries large. Very profitable variety. JESSIE (S). The Jessie is one of the old staridard varieties. We have grown it for many years. The berry is large, bright colored, of a good quality.

HA VERTAND (P). Exceedingly productive. Fruit large and fine. One of the most popular of the well-tested varieties.

PARKRR EARIE (S). A very productive berry if all conditions are favorable. It must have very rich soil and plenty of moisture to mature its crop.

SENATOR DUNIAP (S). A variety that seems to give general satisfaction all over the country. Very productive. Large berry. Very dark red. A profitmaker.

WARFIFID (P). Very productive. Berries quite large. Desirable as a canning berry.

BISMARCK (S). Very productive. Berries quite large. Good pollenizer.

PRUNING AND SETTING. Before setting the plants cut the roots hack, leaving them from four to five inches long, in the case of dormant plants. But slould you defer setting until late in season, when the plant has started new feeding roots, then merely cut off the tip ends of the roots, just enough to even them up.

\section{Special Offer No. 129} 25 plants of any five ahnve varieties, our $\$ \mathbf{\$ 1 . 1 0}$
selection, 125 plants in all, for

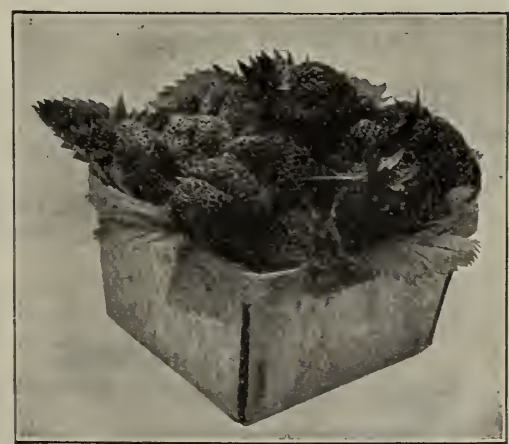

Senator Dunlap. 


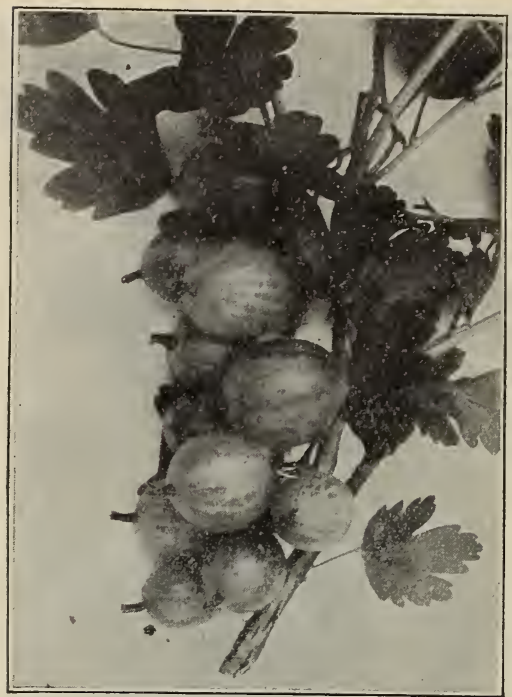

Industry Gooseberry.

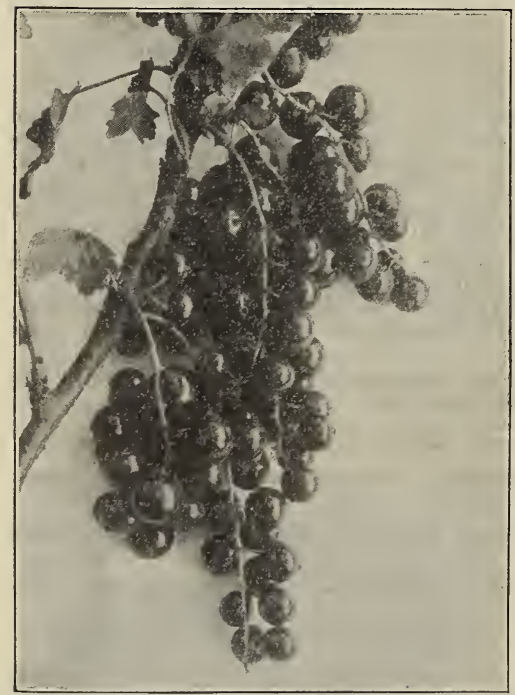

The Dutch Currants.

\section{Gooseberries.}

Should be planted in a good rich soil and well manured once a year. Even more rugged and easily grown than currants, and certainly should be given a place in every garde1. Do not let bushes grow too thick; the fruit will be larger and more plentiful. We offer only the best tested varieties that will do well anywhere. Prices: Strong 2 year plants, 25 cents each; $\$ 2.00$ per $10 ; \$ 15.00$ per 100 .

INDUSTRY. Large, one of the best; fruit red, smooth and juicy.

DOW NING. Large, light green; soft, tender, gooủ flavor; extremely vigorous, hardy and prolific.

HOUGHTON. Most productive; best payer of all. Yield easily 700 bushels per acre; fruit excellent quality.

RED JACKET. Fruit large, red. One of the finest in cultivation.

\section{Special Offer No. 130}

\section{Industry Gooseberries 2 Perfection Currants 2 Cuthbert Raspberries 2 Snyder Blackberries 2 Asparagus Roots 2 Rhubarb Roots}

Enough fruit for a small home. Will pay for itself many times over the first season.

Price Only $\$ 3.00$

\section{Currants.}

Hardy, easily cultivated, standing neglect well, and liberally responding to cultivation and generous treatment; indispensable for table use, jellies, etc. No garden is complete without them. Set four feet apart in rich ground. If the currant worm appears, dust witl hellebore. All 2 year plants well rooted and strong. Prices: 2 year strong, 20 cents each; $\$ 1.75$ per 10 ; $\$ 15.00$ per 100 .

PERTECTION. Very large bright red; a great hearer. The Perfection has a long stem, making it easy to pick. Excellent for jell, jams, etc.

RED DUTCF. Well known old variety, very productive; excellent quality.

VICTORIA. Red, long bunches, very productive. One of the best.

WHITE GRAPE. A white currant. Berries large. Very productive. Sweet and mild, excellent for table use.

WrITE DUTCF. A white currant. IVell known old variety of excellent quality. 1eading well tested BIACK CHAMPION. The leading well tested
Black Currant, very productive. Excellent quality; strong grower.

\section{Raspberries.}

Plant 4 feet apart each way. Prices: Strong roots, each 15 cents; $\$ 1.00$ per $10 ; \$ 6.00$ per 100 .

CUTHBERT. (Red) A strong hardy variety. Berries large; excellent quality. One of the best.

COTUIMBA. (Red) Berries of good size and flesh very firm. Excellent for market and canning purposes; productive.

KA_YSAS. (Black Cap.) A valuable variety. Extra hardy; berries large. A good shipper. GREGG. (Black Cap.) O1d
reliable market variety. large.

\section{Blackberries.}

Prices: Strong roots, each, 15 cents; $\$ 1.00$ per $10 ; \$ 4.00$ per 100

SNYDER. One of the best. Berries juicy sweet and of fine flavor. Large and productive.

ANCIENT BRITON. Another hardy variety. Ripens after the Snyder. Very valuable.

\section{Asparagus.}

Very profitable and easily grown. Prices: Each, 10 cents; 50 cents per 10 $\$ 2.00$ per 100

CONvers COIOSSAI. Produces large tender shoots.

COLUMBIA MAMIMOUTH. A variety of mammouth size.

\section{Rhubarb.}

Prices: Strong roots, each, 15 cents; $\$ 1.25$ per $10 ; \$ \$ .00$ per 100

IINNEUS. Early and tender.

GIANT. Fine quality. Best ior canning.

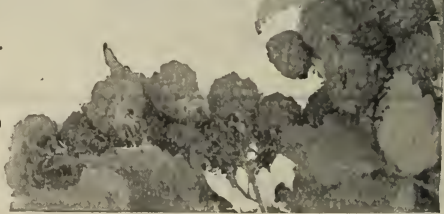


FINE HEDGES add so much to the appearance of property, and are everywhere coming into more general use. They look so neat and attractive, last longer than fences and cost less. When ouce established they require little care and attention. They may be cut and sheared at will, and they grow nore beautiful every year. We grow hedge plants in immense quantities, fine thrifty healthy stock. We can ship you fine stock at a reasonable price. Look over our list of varieties, and note our low prices. Every home slould have a strip of beattiful hedge. Results may be secured in a very short time, pro. viding you give young plants care and cultivation. A hedge needs some shearing to prevent openings, and keep it growing to symmetrical form. Every hedge should be trimmed once or twice each year. June is a good month for the work.

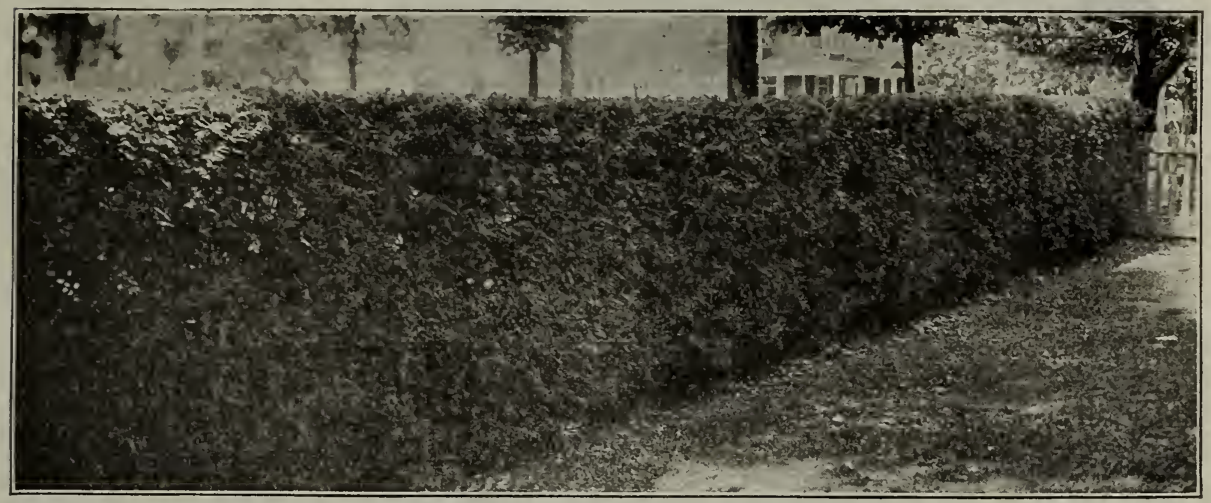

American Arbor Vitæ Iledge.

\section{AMERICAN ARBOR VITAE FOR HEDGES.}

The American Arbor Vitæ is a general favorite. For years it has been planted over all sections of the country. It cannot be too strongly recolwmended. Can be sheared to any shape and may be kept low and dense, or trained to a height of eight to ten feet according to your desire. Always grows compact and retains its lower branches. Plant our small-sized Arbor Vitæ 1 foot apart; the medium-sized plants, 18 inches and the 3 to 4 feet sizes, 2 feet apart.

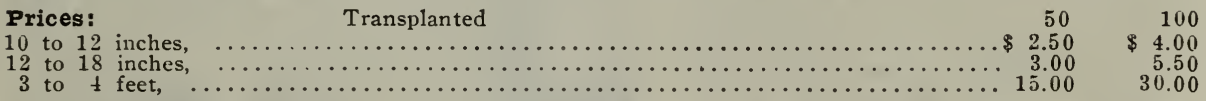

HFMIOCK HEDGES. Nothing in our opinion is so peculiarly attractive and beautiful as a well kept Hemlock Hedge. Either as an ornamental boundary, or for a protective screen, no other Evergreen can equal this in grace or beauty. Always green and cheerful throughout the whole year. An impassible barrier to winds and storms, easily clipped and remarkably beautiful when properly cared for. Of rapid and dense growth and free from disease. True, Hemlocks cannot be formed into a defensive barrier against the incursions of unruly cattle, but in beatifying your homes and endeavoring to create additional attractiveness in their surroundings, we desire something more than the merely practical, and we therefore insist that there can be no place, however small, but what may receive an added charm by the introduction of a neat Evergreen Hedge such as the Hemlock has proven itself to be.

Transplanted
Prices:
10 to 12 inches, $\quad \ldots \ldots \ldots \ldots \ldots \ldots \ldots \ldots \ldots \ldots \ldots \ldots \ldots \ldots \ldots \ldots \ldots \ldots \ldots \ldots \ldots \ldots \ldots \ldots \ldots \ldots$

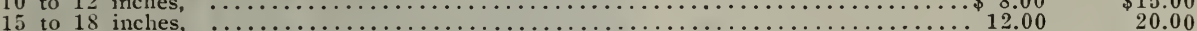

JUNIPFRUS GIAUCA. Evergreen hedges are divided into two classes, which in the planting, selection of varieties, and after management differ very essentially from each other. The first is a well sheared, dense compact hedge to please the eye by symmetrical proportions. The second consists of a line of trees planted to hedge form, the plants set further apart and each sheared separately as an individual, always maintaining a little open space between each specimen. Beautiful informal hedges are formed in this manner. We recommend for this purpose the hardy Juniperus Glauca, or Silver Blue Cedar. Its graceful habit of growth together with superb form and attractive foliage, is not excelled by any other variety.

Prices:

Transplanted

10

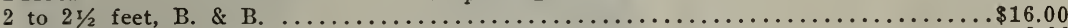

9.00

$\$ 37.50$

20.00

HFDGFS, WINDBREAKS, SHETTERS AND IIVE FFNCES. By E. P. Powell. A treatise on the planting, growth and management of hedge plants for country and suburban homes. It gives accurate directions concerning hedges; how to plant and how to treat them; and especially concerning wind-breaks and shelters. It includes the whole art of making a delightful home, giving directions for nooks and balconies. 140 pages, $5 \times 7$ inches. Cloth, 50 cents. 


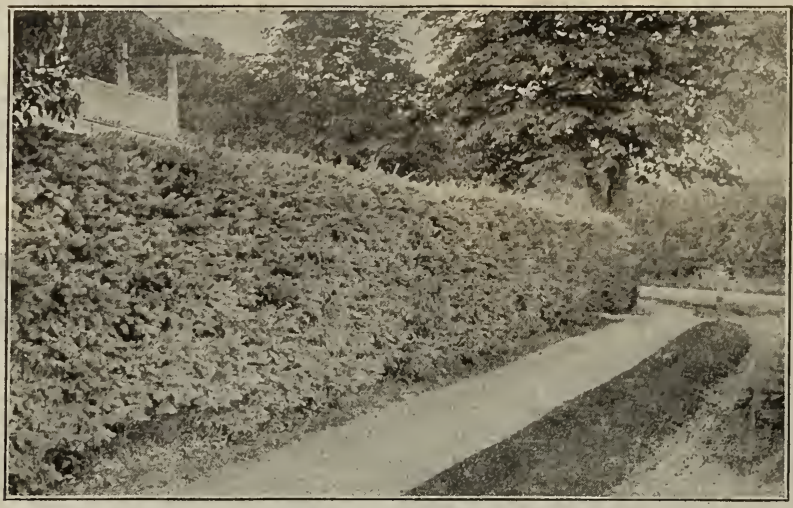

Norway Spruce Hedge.

\section{NORWAY SPRUCE HEDGE.}

IVe recommend this tree as being especially well adapted for hedge planting. Rapid in growth, forming a compact hedge in a short time. Can be sheared into any desired form.

See illustration and note what beautiful hedges are obtained from planting Norway Spruce. They may be grown six, eight or even ten feet tall, always retaining their perfect form.

Prices: Transplanted. 10 to 12
inches, $\$ 1.00 \$ 2.25 \$ 4.00$ $\begin{array}{llll}12 \text { to } 18 & & \\ \text { inclies, } & 1.50 & 3.25 & 6.00\end{array}$ $\begin{array}{cccc}18 \text { to } 24 & & & \\ \text { inches, } & 2.00 & 5.25 & 10.00\end{array}$

\section{HARDY AMOORE RIVER PRIVET FOR BEAUTIFUL HEDGES.}

Today this is the best and most reliable Hardy Hedge Plant we offer. A remarkably vigor ous grower, compact and regular in form, with glossy wax-like foliage of bright green color. It is recognized the world over as the "Ideal Hedge Plant." It thrives in all kinds of soils and situations, in sun and shade, in smoky cities around railroads and smoking factories. In the South it is practically Evergreen, retaining its beautiful green leaves all winter. Amoore River Privet can be cut or sheared into any desired form. Is absolutely free from disease and insect attack. Amoore River Privet can be grown to low or high hedges, simply by the amount of shearing it receives. Fine for hedges between city lots, on large rural grounds, parks, cemeteries, in single groups or with other shrubs, also as screens to outbuildings, fences, etc. Privet if allowed to grow naturally, without pruning, will give a finishing touch to the beauty of any lawn or garden, but best results are obtained when sheared semiannually. Prices: Transplanted, $1 \mathrm{~s} / 2$ to 2 feet, $\$ 3.50$ per $50 ; \$ 6.00$ per 100 .

PIANTING DIRECTIONS. After determining the location for the hedge, the strip of ground should be plowed or dug over deeply for a width of two feet, and the plants set in the center of this pulverized strip. The proper distance apart for the plants will be determined by their size. Plants 12 to 18 inches tall-one foot apart. Plants 18 to 24 inches and 2 to 3 feeteighteen inches apart. Cut back severely as soon as planted, all Hedge plants except Evergreens. Keep the soil cultivated in summer, and mulched in winter.

JAPAN BAREERRY (Berberis Thunbergii). Of all the deciduous shrubs we know, we believe this is the most valuable for making a low dwarf hedge. It is of low, regular and compact growth and requires very little pruning. It has fine thorns and small round rich green leaves that change color in the Autumn to a fiery crimson. The hedge is made still more beautiful by great numbers of pretty drooping yellow flowers which are followed by bright red berries. It is frequently planted singly, and is one of the handsomest flowering shrubs we have. Our stock is the real rare kind, and remarkably fine in every way. It is made from cuttings and not seedlings. Plant about 12 inches apart. Price: Transplanted, 1 foot, $\$ 6.00$ per 100 .

SPIREA VAN HOUTTI. Rapidly becoming popular as a hedge plant, and justly so on account of its charming graceful habits, and profusion of delicate white blooin, which appcars early in the summer. This variety is easily started, sure to grow, and requires little attention.

Prices: Transplanted $\quad 100$ 1 to $11 / 2$ feet $\ldots \ldots \ldots \ldots \ldots \ldots \ldots \ldots 10.00$

ROSE HEDGES are certainly coming to be more and more popular as people learn about the splendid qualities of the Wild Roses for this purpose. They make neat, compact, uniform growth and the thick, bushy mass of glossy, crinkled foliage gives a particularly fine appearance. Price: 1 foot, $\$ 5.00$ per 100 .

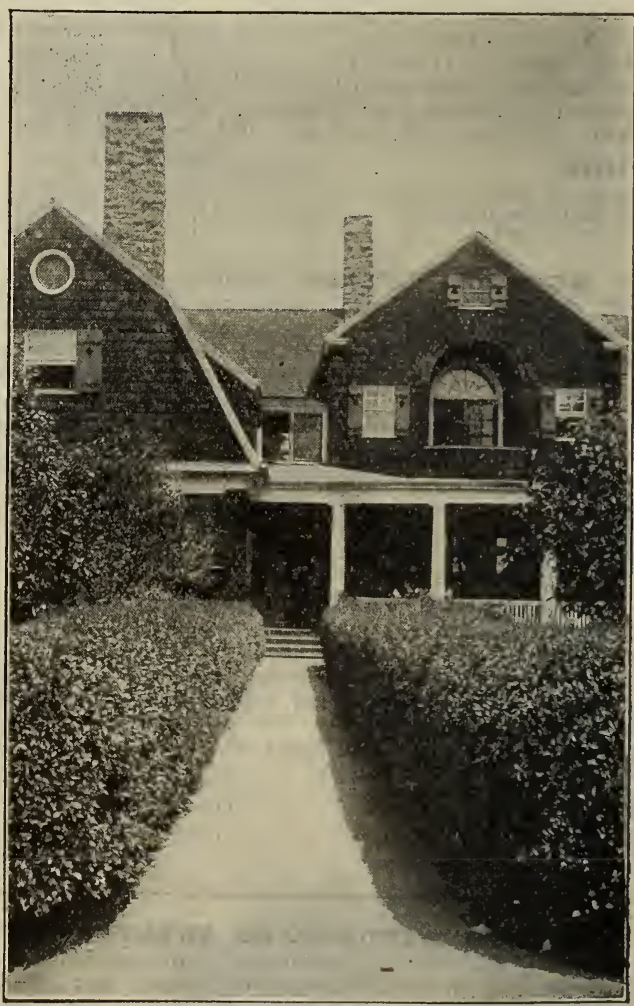

Amoore River Privet Hedge. 


\section{LIVE FENCES OR STOCK PROOF HEDGES.}

THE OSAGE ORANGE is one of the most valuable trees for strong stock-proof hedges. Not only does the Osage Orange produce a fine hedge, but acts as a wind-break as well. Sometimes Black Locust, Honey Locust, Ash and Walnut are planted with Osage Orange. Thus your hedge acts as a fence and stock shelter. OSAGE ORANGE, I year, $\$ 1.00$ per $100 ; \$ 4.00$ per 1.000

Although making a specialty of FVIRGREFNS and having the largest stock in America, if not in the world, we also conduct six other complete departments; thus we are able to furnish our customers with almost everything in the Horticultural line.

EVERGREEN DEPARTMENT,

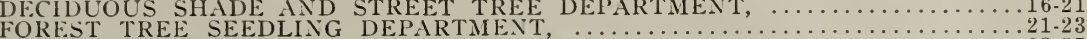

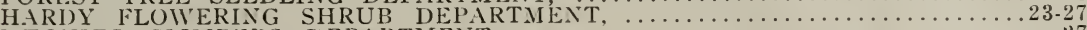

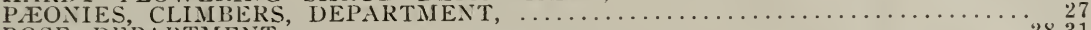

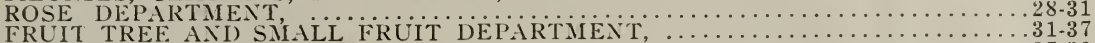

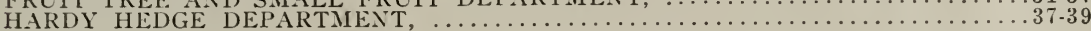

\begin{tabular}{|c|c|}
\hline $12 R 142$ & $\begin{array}{l}\text { These beautiful Japanese Maples are among the rarest and most } \\
\text { low-growing trees we have for door-yards, lawns and park planting. } \\
\text { Highly valuable on account of their neat, compact growth and wonder- } \\
\text { fully bright-colored foliage, Spring, Summer and Fall, deep blood red, } \\
\text { rich crimson scarlet, golden yellow, etc. They make nice bushy little } \\
\text { trees, and being scarce and difficult to propagate the price is always high } \\
\text { Seen in all the finest places. We offer the cut leaved variety, deep red } \\
\text { in color, } 2 \mathrm{~L} / 2 \text { feet, } \$ 1.50 \text { each; } \$ 12.50 \text { per ten. }\end{array}$ \\
\hline
\end{tabular}

J A P A I S E WEEPING CHERRY. Most beautiful of all weeping trees. Graceful, drooping branches, literally covered with delicate white blossoms, giv ing us the handsomest and most picturesque of all flowering trees. Thrives on any good soil and requires no care, other than a good mulch during the winter months When in blossom this tree appears like a huge bank of snow, so profusely do the blossoms hang from the slender branches. IVe take pleasure in being able to furnish these fine trees to our friends and customers. Every tree is grafted and receives careful attention, that all may grow to perfect form. Even wher grafted on tall stems its slender branches sometimes sweep the grass in graceful garlands. Price: 4 to $4 \frac{1}{2}$ foot stems, each $\$ 2.00$.

ROSE FLOWERED AIMOND. A small tree growing ten and twelve feet tall, straight and upright in form. Beautiful rose colored flowers appear early in the spring before the leaves are full grown. The branches and leaves are entirely hidden by the masses of delicate colored flowers, very double with rose shape. Price: 4 to 5 feet, $\$ 1.50$, each.

THE EMPRESS TREF. A most remarkable and beautiful tree, both on account of its hand some flowers and exceedingly large leaves. During the winter the clusters of flower buds for the ensuing year, together with the fruit pods of the past season, hang side by side. Its erect panicles of handsome deep purple flowers a foot long the great soft green heart-shaped leaves frequently measuring 18 inches across, give an effect long to be remembered. Grows very rapidly,

forming a fine large round tree. Something entirely different from any other tree and attract: much attention wherever grown, as it has a distinct beauty of its own. Price: 4 to 5 feet, each, $\$ 1.50$.

\section{Special Offer No. 131, 8 Beauties $\$ 5.00$}

1 Empress Tree, 4 feet.

1 Japanese Weeping Cherry, $4 \mathrm{~T} / 2$ feet.

1 Japanese Cut-Leaved Maple, $21 / 2$ feet.

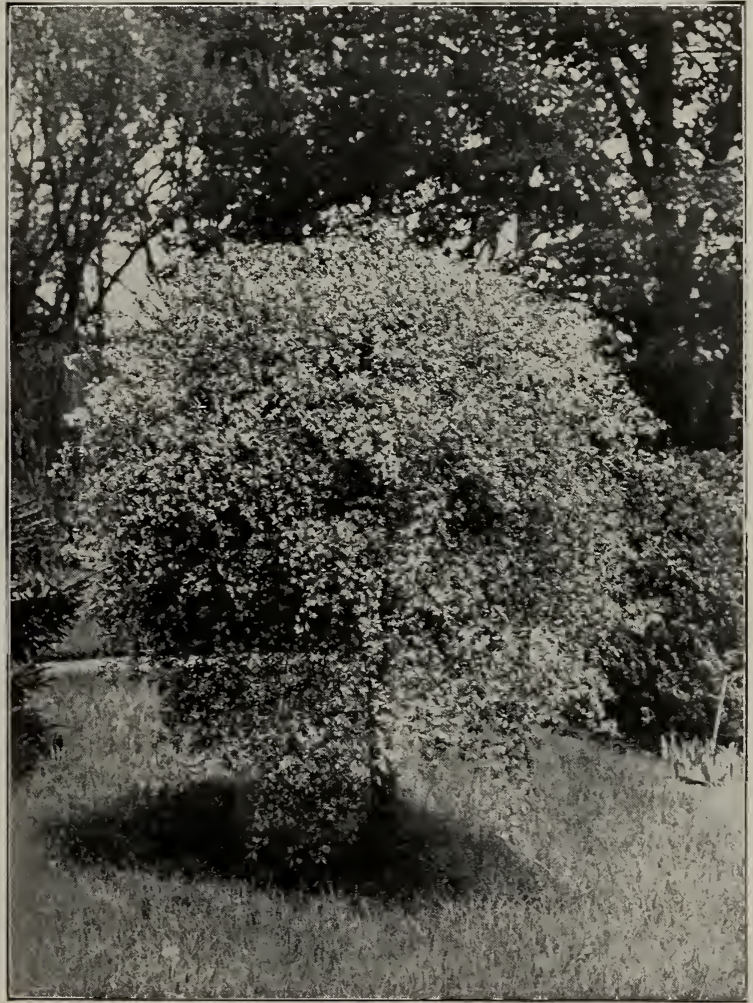

Japanese Weeping Cherry.

\section{uties $\$ 5.00$}

1 Rose Flowered Almond, 4 feet. tion, $1 \frac{1}{2}$ to 2 feet. 



\section{OR D E R S E E T}

\section{HILL, Evergreen Specialist \\ D u n d e e, $\mid$ i 1 i n o i s.}

Please send following Order by

Write Freight or Express

Name ( Very $)$

Please don't write here

P. O. Box

or Street

R. F. D. No. (

Date

1909

Post Office,

County,

State,

$\left.\begin{array}{l}\text { Express or } \\ \text { Freight Office (If different } \\ \text { from P. O.. }\end{array}\right)$

Amount Enclosed:

$\$$

State whether Cash. Draft.

P.O. Order. Express Noney

Order or Stamps.

NOTE.-Read carefully iustructions in ratalog regarding "trausplants" and "seedlings" also articles designated "Ball and Burlap "

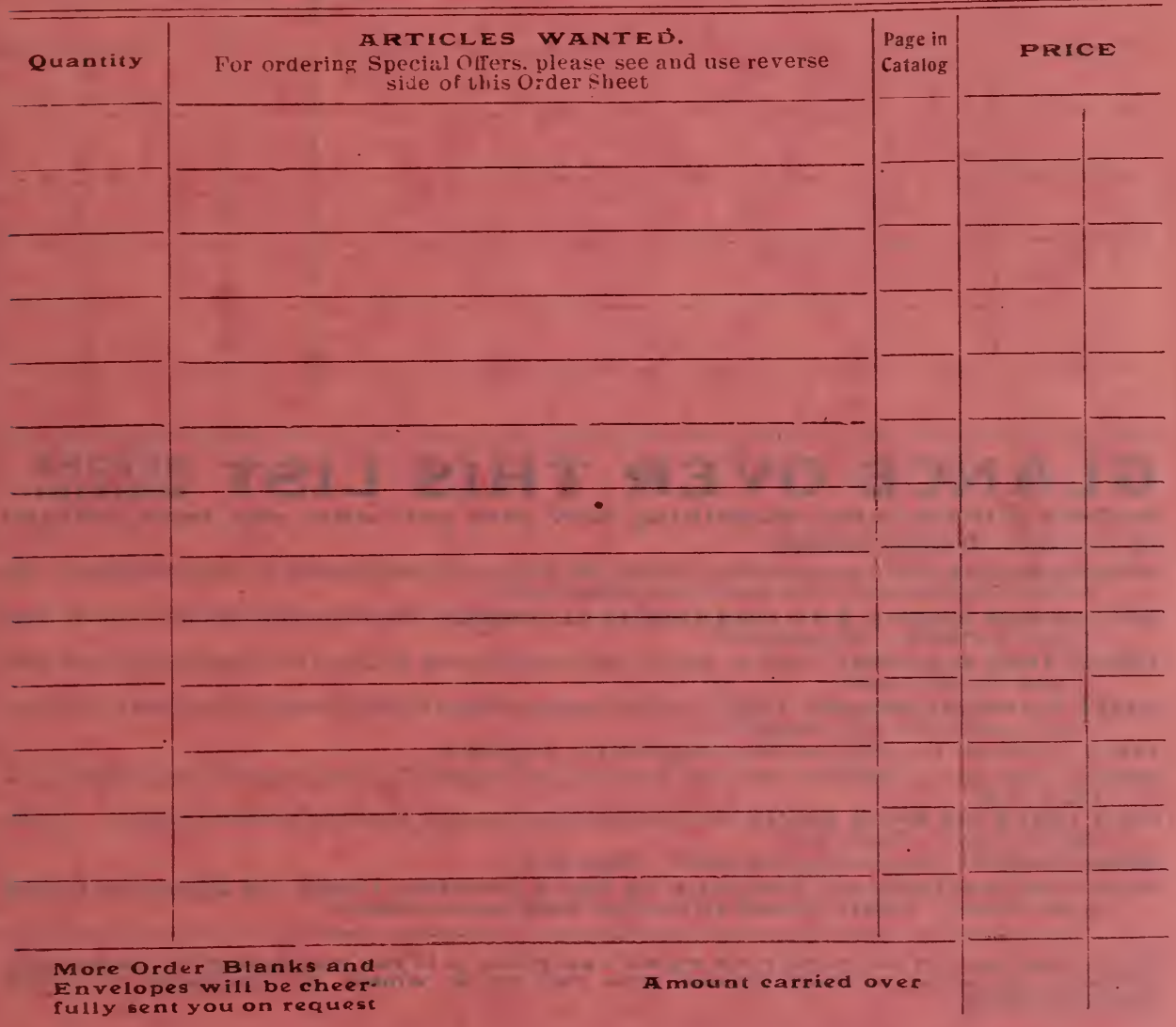




\section{ORDER SHEET FOR SPECIAL OFFERS}

You are almost sure to want some of these special value collections, which for your convenience in ordering we have numbered (see catalog and bargain sheet). These are Money-Saving Sets. Please order by number or name and carry out price as shown below.

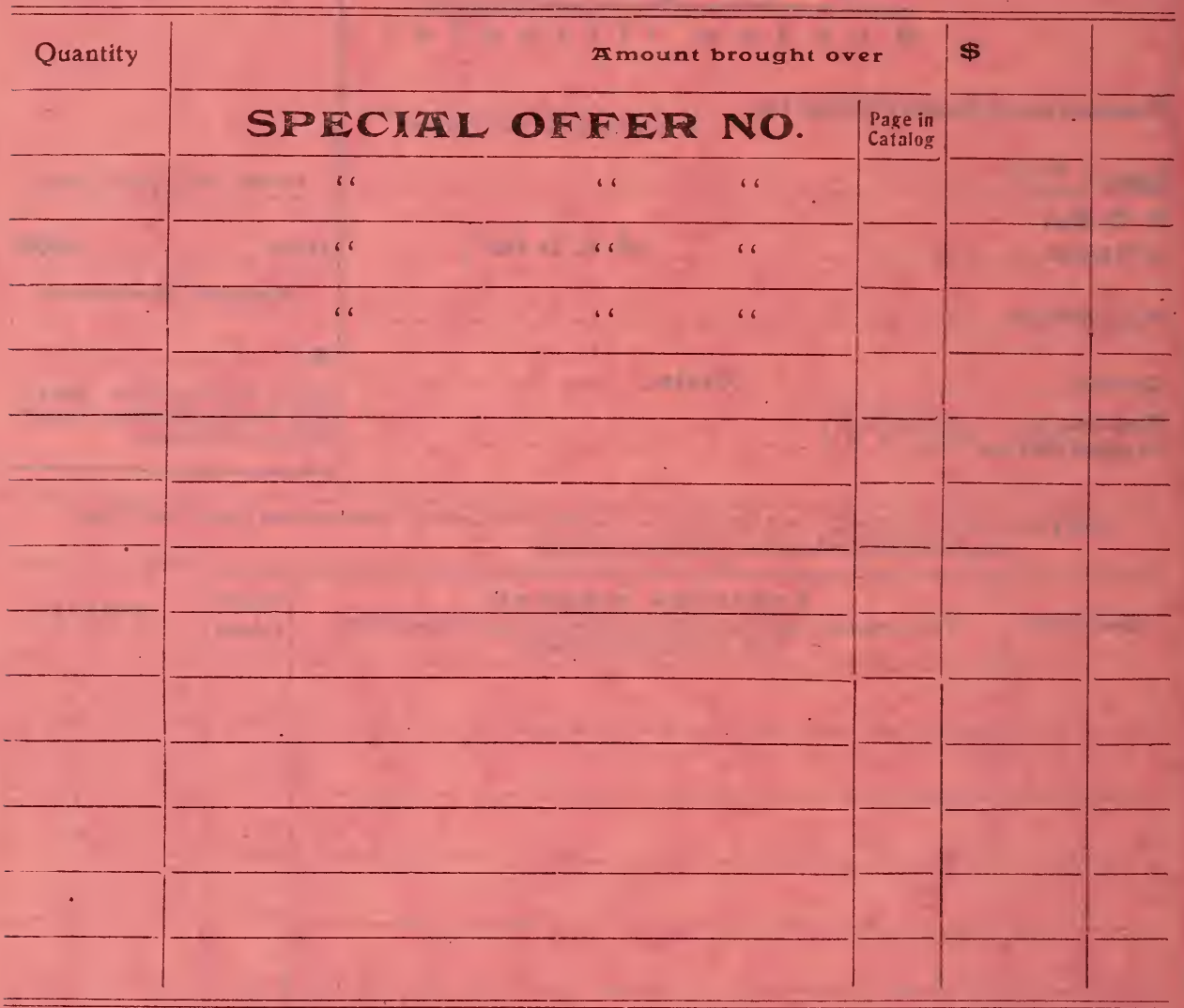

\section{GLANCE OVER THIS LIST BEFORE}

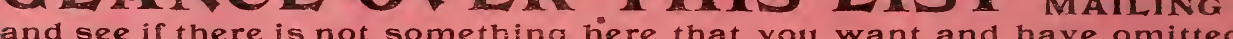
to include in your order:

EVERGFEENS-Hill's evergreens are known the world over and famous for their hardiness. For detailed descriptions of each variety see pages 4 to 16 .

DECIDUOUS SHADE AND ORNAMENTAL TREES-Have you provided for a row of LTEes on your tree bank. See pages $16-21$.

FOREST TREE SEEDLINGS-Turn to page 22 and note the profit derived from planting a siagle acre of trees fur fence posts.

HARUY FIOWERING SHRUBS-There is nothing as fine as these for the corners of your lawn and borders of your drive. See vages $23-3{ }^{2}$

VINES-"Nature's Drapery," and very inexpensive. Spe page :2

ROSES-Have yuu CLIMBERS for your porches and archways as well as the beatiful Bush Roses. Pages: $28-31$.

FRUIY TREES AND SMALL FRUITS-DLes anyone near you grow fruite for the home narket. If not why don't you. Pages $31-37$.

HEDGE PLANTS-Very eflective and pretty. Pages 3i-39.

If you order these things now, it may save you loss of extra time, trouble and expense of sending in two orders. It pays to order all you want while you are about it.

While making out your order we would appreciate it if you would send the names and addresses of some of your friends who you think would be interested in Hill's splendid offers. 
of the salisfaction. Dont fail to try one or more of these bargains. Tuke your choice of any of the following thirty-four $\$ 1.00$ flakages, one or more, by mail, pust-paid, to any post ollice in the United States, or any of the sixten by treight, prep.id, to any railroat station in the United States east of the Rockv Mountains. At the very low price these Bargain Lots ale offered l cannot chänge. divide or alter them only as described on this sheet. No replacements furnished as per calalogue. Cash Must Accompany Order.

34 Packages No. I in 36, sion inill EVERGREEN SEEDLINGS I-10u Scotelı I'ile a years. + to (; In.

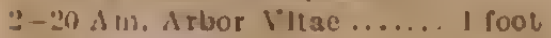
: $-100 \Delta i n$ Arluor V́ltar.... : i lears I-IU0 Auntriall l'ine...... to ti inch

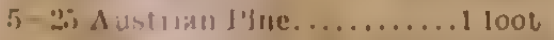

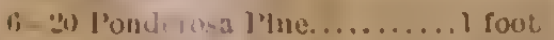
: Ino l'onderosa I'lue... + lo li meh $x-3.1$ ack l'ine ............. foot

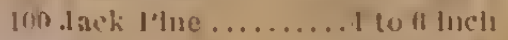
l(k) Mhlilte l'inc........t to is irch $11-100$ lialsam rilr........t to ti inch 1:- Ino lied sirute......... t (1) ti liscli 1:i-3.; . Vorway Spruct...... . . 1 fout

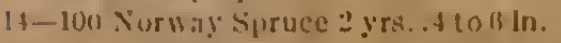

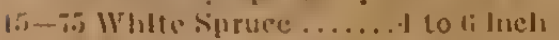
li-2.; Xorlman's litr........ + tuch 17-3. Flexlls l'ine ........ to ti lich 15-100 l)ouglas Spruce.... t to ti incli $19-i x)$ Iied C'edar . . . . . . . . . 1 year. 20 - it) IBlue Spruce 2 yrs ..... to to + incli 21 -2.5 . Ables Concolor..........2 years 2.2 - len Chi, Com. Ar. Vitate..t w (ilu.

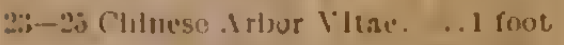

FOREST TREE SEEDLINGS $3-50$. Inrerlcan liecell ....10 to $1: 2 \mathrm{i}$.

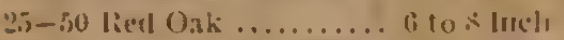

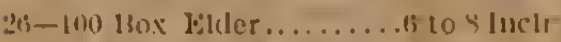
¿i- I00 Sugar . Vaples....... b to s lncli 2x-l00 Wilte . Isli ........ li to s Incls ?!)-l(n) Whlle Fin......... li to 8 Inch $30-100$ Yellow Locisi ... . (0 to 10 lixch

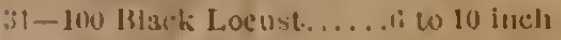
:3-10(0) soft .1aple......... (i to 8 inch 33 lox)('atalpa (IIardy) ...6 to 8 incls $3 t$ is) Europican Larch..... to to 8 inch

\section{Bargain Lots, By Freight, Prepaid}

\section{TRANSPLANTED} EVERGRIEENS

The tree's hore oftered ise all .No. 1 and lirse class in every way. Two or thus times transpianted, therefore well rubet. They caninot fall to

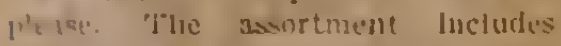
many of the newer sirl higher prleed

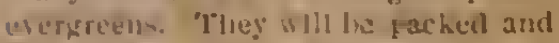
delisered w your ncarest railroal sta- tion. lirelghit elrarges prepald upou recelpe of prlce natmed, except liv's i1, 52. ins and it.

\section{LIST NO. 36. PRICE \$10.00} lo lslack llill Spruce ........ I v fect I1 Willte l'he............... 10 lial-am Fir ............... 20 . Vorway. Spruce ........... 11) Amerlesu drloor Vitae.... I3/3 10 Ancerlean White Spruce... I':

LIST NO. 30. PRICE \$8.00

+ black Illl Sprite ....... 1\% 4. Torway Siruce.......... I 5 IVlilte line............... 4 latsain lilr . .............

4 Amerlcin .I rlur vitae...... 5 Wlilte spruce .............

\section{NOTICE!}

Don't overlook this largaln, 1500 llue transplianted trees, is iarletles, ill for \$10. 10 .

LIST NO. 3T. PRICE \$10.00

10 lilack Illl spruce... . . .... I fout

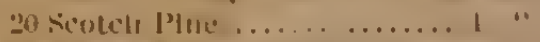
s.5 While I'ine............... " :0 Whiltu Spruce.............. " is Xorway spruce ........... 21) Bull l’ine ............... " so Anerleau Arbor Vilas....... " 10 lialsam loir .............

LIST NO. 36. PRICE \$6.00 10 lilack 1111 suruce........... 1 foot 10 s.cotch l'Ine............... lo White l'Ine.............. . "I Whlte Sprnce............ I " 10 Norway spruca $\ldots \ldots \ldots \ldots \ldots 1$ " ") Arbor 1 itae............... " 10 liull l'ine ................ ".

LIST NO. 39. PRICE \$12.00

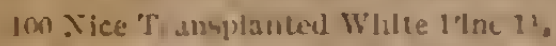
10 - feet, excellentalue: regu r price

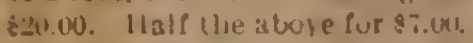

LIST NO. AO. PRICE 10.00 50 llull l'lts........... In to 12 Ituch

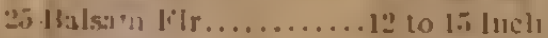

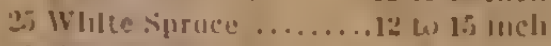
2i) Vurway sorme .......

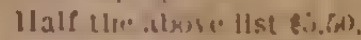

LIST NO. 41. PRICE 10.00 livtra fioml liargalns for all cllnate.

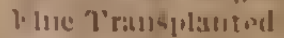

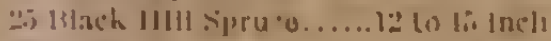

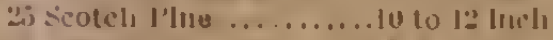

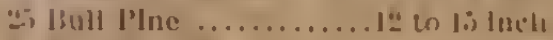

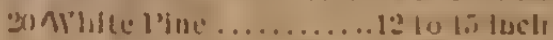

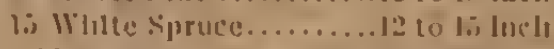
'Try this lot. Ji Hils llst for sij.io.

LIST NO. 42. PRICE 16.00

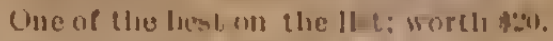
Fine Tramsplanted-

lo0 Whilte spruce.............2 fect Half the above for ax.ur).

LIST NO. 83. PRICE 18.00 licgular price :20.01).

Fine T'rasuplanted

$l(x)$ Balsam toir. . ........... 2 feet

llalf tlie above llst for thon.

LIST NO. 4A. PRICE \$10.00 lolue iramblantel-

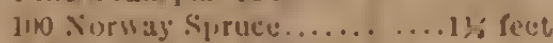
II:alf the aluve llst for ti.0.0.

LIST NO. 46. PRICE 16.00 kixtra Nice, Twlee Trangjplancel.

10n Norway spruce.......... \& feet

llalf the above llst for $2 *(x)$.

LIST NO. 46. PRICE 10.00

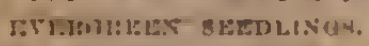

A Snall Nurary for $910 \mathrm{um}$.

100 Xoray Spruce ....... (u) 10 Itxch 100 1 ustrian d'ine ......... to to s lincl. I(i) seatch l'inc..........., to " firch

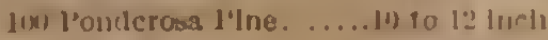

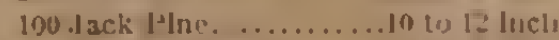
110 Luuglas spruce. . .... if wa liscit IIalf tie alyose fir 85.50 .

\section{MILL, Evergreen Specialist DUNDEE, ILLINOIS.




\section{GRE}

LIST NO

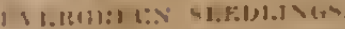

unt lidal am lir.. , .... \& ie li mel

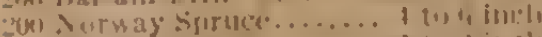

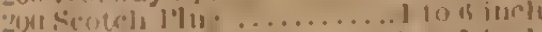

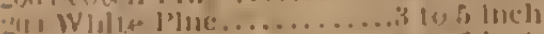

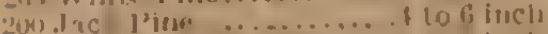

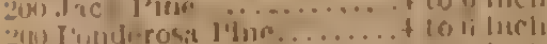
llalf the above llst fur se.t(k).

1.1ST NO. 48. PRICE \$10.00 (Inc of tho lyest lairgalus ln the llst.

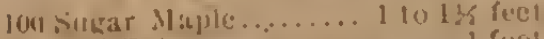

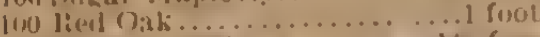

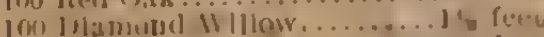
1101 1

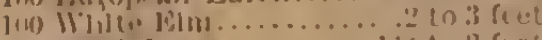

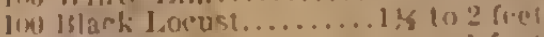

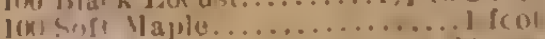

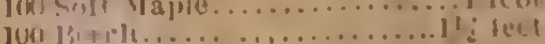

11 sil !n atrove llsi for sti.14).

LIST RO. 49. PRICE $\$ 10.00$ In cacerillomall valuatule collecellom for the sul th-Wrsiern 4 intes, stshthern

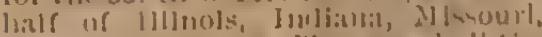

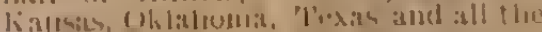

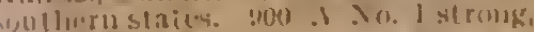

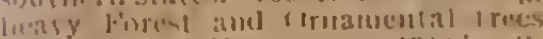
aiil sin clumec bivergrevens lonu in all.

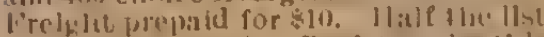

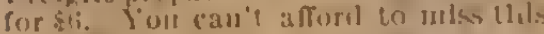
Litrg:til, as follows:

an lilach l.ocust. . .... ... 20 to : fect

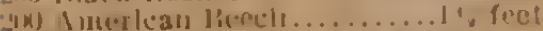

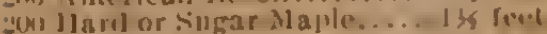

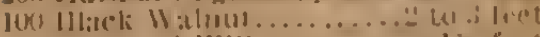

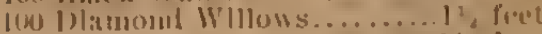
I0i) Suft . Mables......... I to l's fret

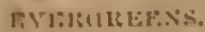

100 lied sipruce............... $(1, n) t$

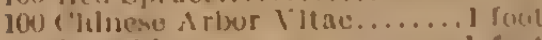
100 dack l'lua................ I firut lon levllow l'lue ............ . . foul

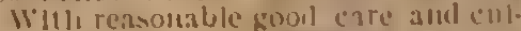
tlvinlun the alwe $133 x)$ irees is 111 adil fo llue value of ing juralrle farm tlious. anclu of dollars lis a fow years
2.IST NO SO. PRICE BIO.00

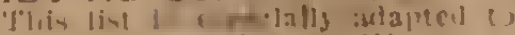

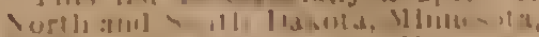

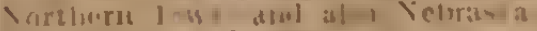
(thlit]ull:a istul lian an.

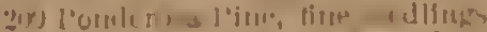

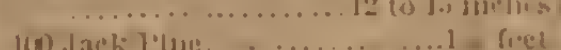

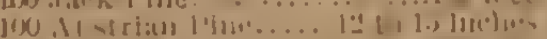

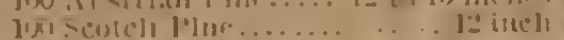

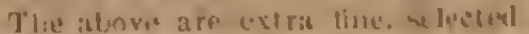

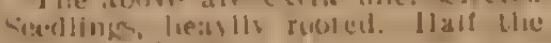
alnve list for $: 4,0(k)$.

\section{Four Last and Best}

l'achicl amel reliverel oul car, imt not prepalel. l'urcliavers munt jas the froiglit un llicene lan four liarsiblus. Dll sultalue for law julanting.

LIST NO. SI. PRICE \$10.00 I wlue : :2h.(h).

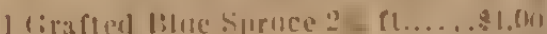

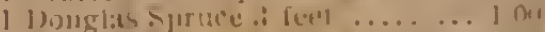

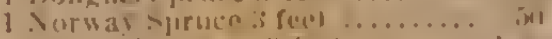

1 Homlich siprt:ee : (1 el ........ l.t)

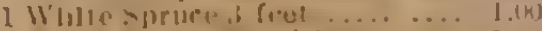

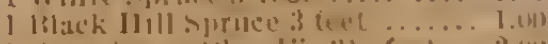

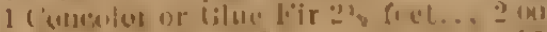

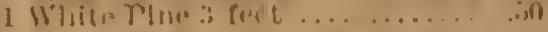

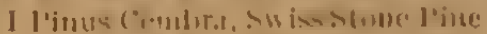

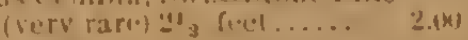

I Jughollwarf l'im, exira bushy

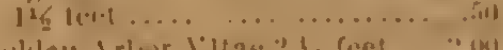

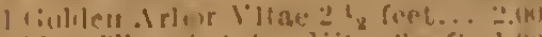

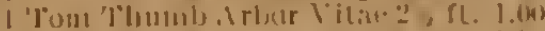

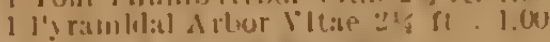

1 liwarf llourey or completa irlour lileac ibe fect.......... 1.00 1. Sluerian . Irlor l'ltat \& feet ... 1.10

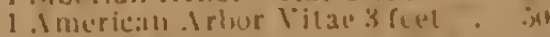
Illa abose eullectlom, lin No.

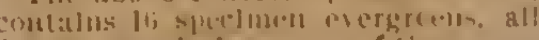
dillesent barictlen, mans cef them news

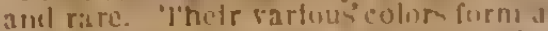
most pleislug cuntrast, frum a lirlglit

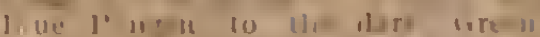
llu lio, \& if siltermin t. Ilen II I

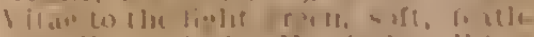

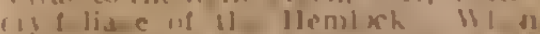
1) - $19 \cdot 1$ is 1 g mal at ri, 111 t.ur

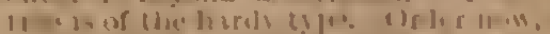

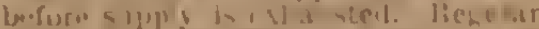

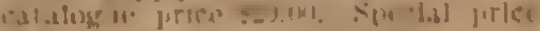

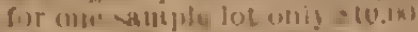

LIST NO S2 PRICE $\$ 20.06$

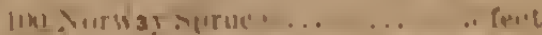

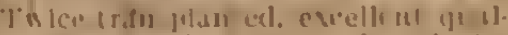
11!, w.1l $r$ ind, i.areiully is reel, for 72 (1). (4).

LIST NO. 53 PHICE $\$ 50.00$ 100 Cholce Trees.

I4 fece-Flve Beat Varietieg

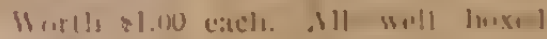
(ur in) 0.1 .

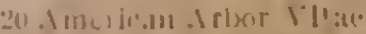

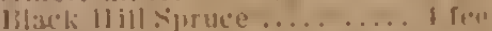

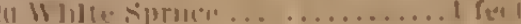

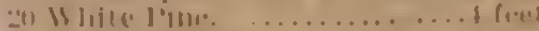

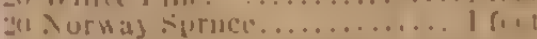

LIST NO. E. CAIR LOTS

li-perially fur thum deollimk wo

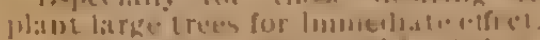

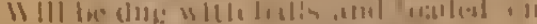
car al le $\rightarrow$ than half $t \mid$ ir inliw.

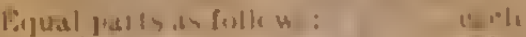

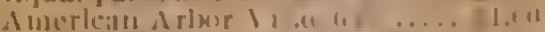

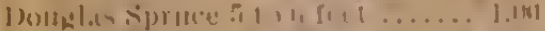

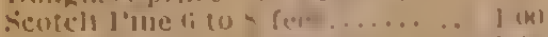

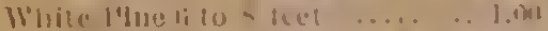

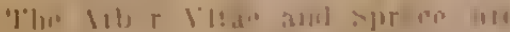

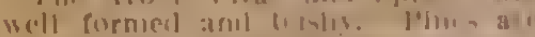

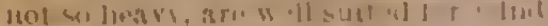
lireaka, slsoller siltites blul i a

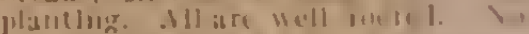

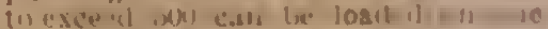

| car. Write for furlit l liffisssi, lim

\section{- - -}




\section{Hill's "NATIONAL" Collection}

$\mathrm{N}$ the panel running across the bottom of outside cover pages we reproduce from photographs six of the best and most valuable Berried and ever offered. It consists of three berried shrubs and three flowering shrubs. The Snowberry has immense clusters of magnificent, creamy white berries which adhere to the limbs throughout the entire Winter. It makes a delightful contrast to the Coral Berry which has coppery colored berries and to the Barberry, whose berries are bright crimson. The flowering Shrubs which consist of White Lilac, Golden IIock Orange and Cherry Red Wiegelia Rosea are simply superb. For striking beauty of flower and delicious fragrance, nothing could be more charming. 'This lovely collection will add a charm to one's surroundings as nothing else will, and the low cost, made possible by the enormous quantity in which they are produced, proclaims it pre-eminently the collection for the

masses. Six Superior Berried and Flowering Shrubs for 65 cents.

Please order as "National Collection."

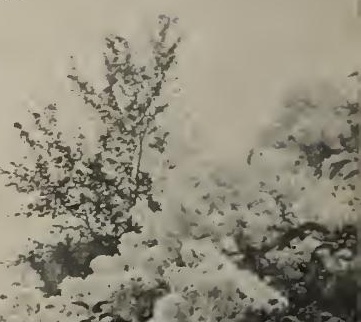

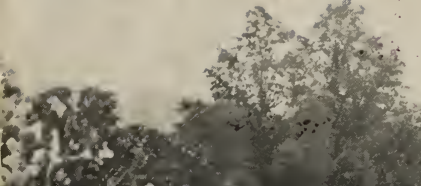

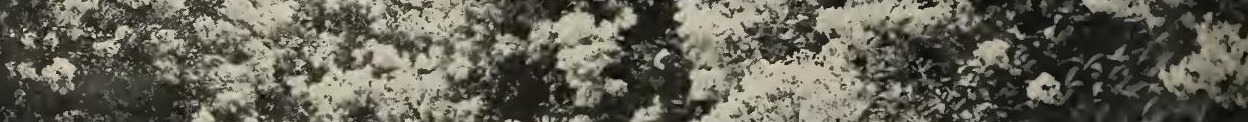
$\rightarrow+x^{3}$

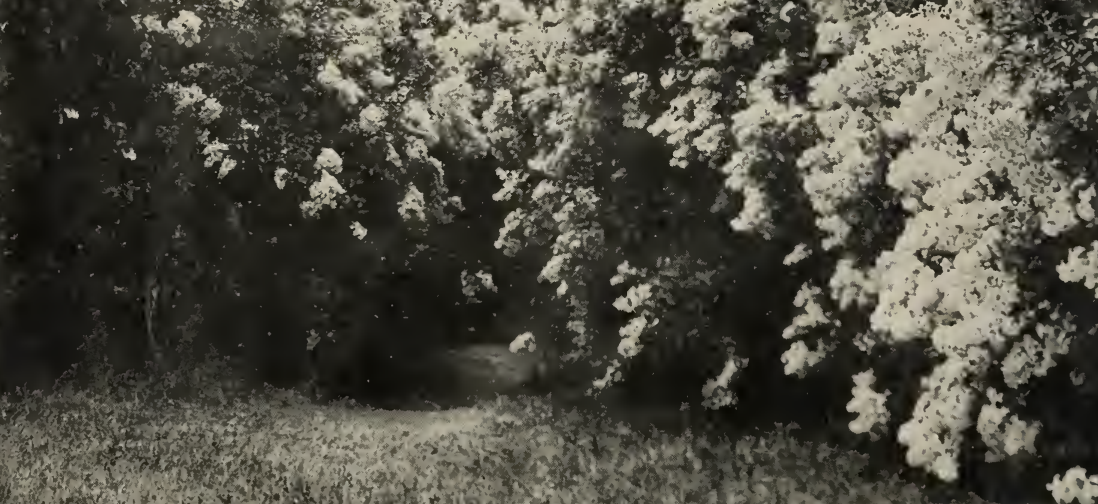

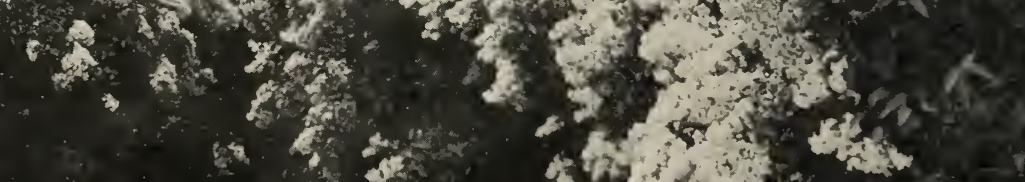

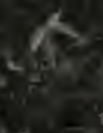
17. क्

$$
x^{2}, y^{2}
$$

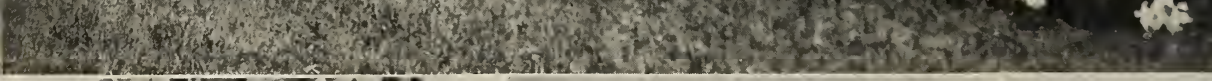
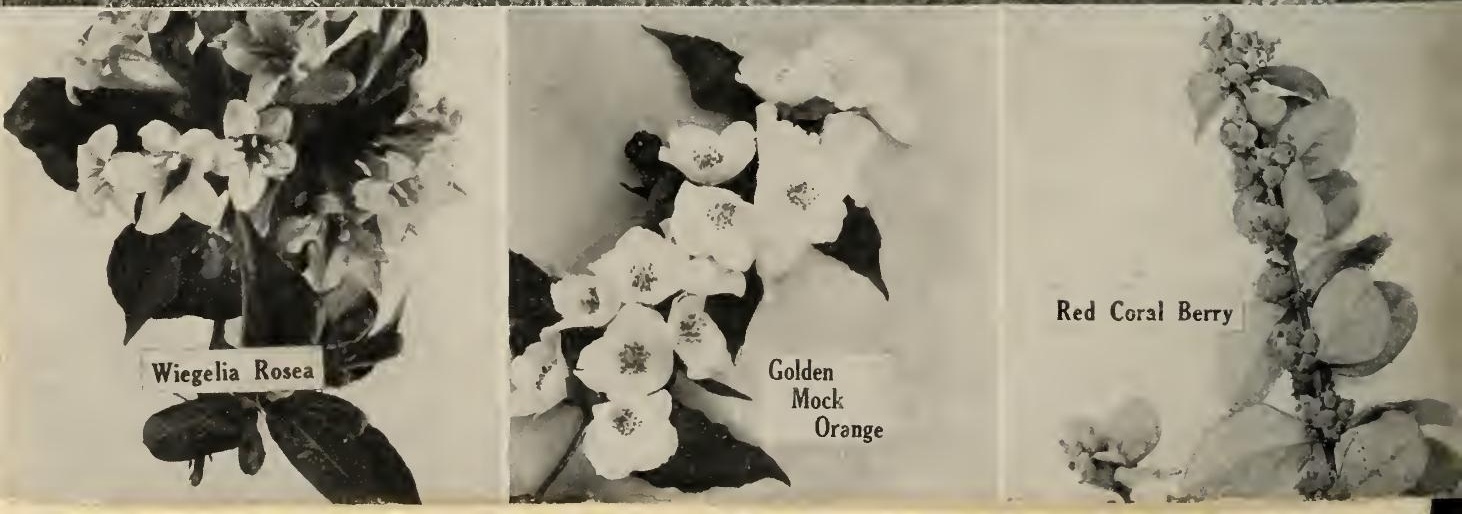